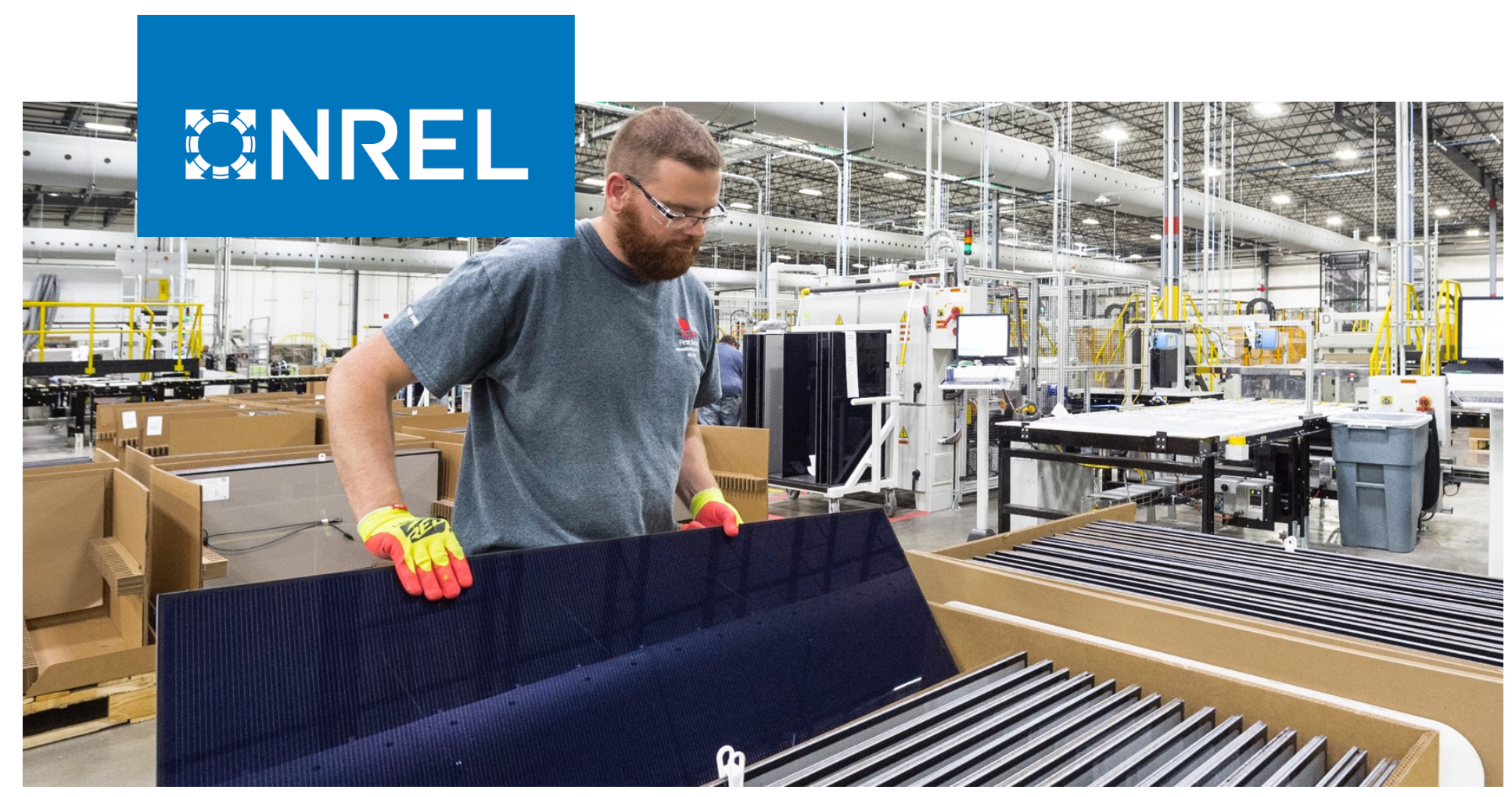

\title{
Solar Photovoltaic (PV) Manufacturing Expansions in the United States, 2017-2019: Motives, Challenges, Opportunities, and Policy Context
}

Brittany Smith, Michael Woodhouse, David Feldman, and Robert Margolis

National Renewable Energy Laboratory

NREL is a national laboratory of the U.S. Department of Energy Office of Energy Efficiency \& Renewable Energy

Operated by the Alliance for Sustainable Energy, LLC

This report is available at no cost from the National Renewable Energy Laboratory (NREL) at www.nrel.gov/publications.
Technical Report

NREL/TP-6A20-74807

April 2021 


\title{
WNREL
}

\section{Solar Photovoltaic (PV) Manufacturing Expansions in the United States, 2017-2019: Motives, Challenges, Opportunities, and Policy Context}

\author{
Brittany Smith, Michael Woodhouse, David Feldman, \\ and Robert Margolis
}

National Renewable Energy Laboratory

\author{
Suggested Citation \\ Smith, Brittany, Michael Woodhouse, David Feldman, and Robert Margolis. 2021. Solar \\ Photovoltaic (PV) Manufacturing Expansions in the United States, 2017-2019: Motives, \\ Challenges, Opportunities, and Policy Context. Golden, CO: National Renewable Energy \\ Laboratory. NREL/TP-6A20-74807. https://www.nrel.gov/docs/fy21osti/74807.pdf.
}

NREL is a national laboratory of the U.S. Department of Energy Office of Energy Efficiency \& Renewable Energy Operated by the Alliance for Sustainable Energy, LLC

This report is available at no cost from the National Renewable Energy Laboratory (NREL) at www.nrel.gov/publications.

Contract No. DE-AC36-08GO28308
Technical Report

NREL/TP-6A20-74807

April 2021

National Renewable Energy Laboratory 15013 Denver West Parkway Golden, CO 80401

303-275-3000 • www.nrel.gov 


\section{NOTICE}

This work was authored by the National Renewable Energy Laboratory, operated by Alliance for Sustainable Energy, LLC, for the U.S. Department of Energy (DOE) under Contract No. DE-AC36-08GO28308. Funding provided by U.S. Department of Energy Office of Energy Efficiency and Renewable Energy Solar Energy Technologies Office. The views expressed herein do not necessarily represent the views of the DOE or the U.S. Government.

This report is available at no cost from the National Renewable Energy Laboratory (NREL) at www.nrel.gov/publications.

U.S. Department of Energy (DOE) reports produced after 1991 and a growing number of pre-1991 documents are available free via www.OSTI.gov.

Cover Photo by Dennis Schroeder: NREL 47974.

NREL prints on paper that contains recycled content. 


\section{Acknowledgments}

This work was funded by the U.S. Department of Energy's Solar Energy Technologies Office. We would like to acknowledge the following individuals for their helpful comments, corrections, and contributions:

Sam Baldwin (EERE)

Becca Jones-Albertus (SETO)

Cora Dickson, Jeff Eversman, and Christian Herman (Department of Commerce)

Scott Stephens (Clearway Energy)

Llewelyn Hughes (ANU)

Xiaojing Sun (Wood Mackenzie)

Colin Cunliff (ITIF)

Jarett Zuboy (Independent Contractor)

Dan Bilello, Tina Eichner, Jill Engel-Cox, Mike Meshek, and Gian Porro (NREL)

Finally, this report was written with input from the companies in the case studies section, from sources that would like to remain anonymous. 


\section{Glossary \& List of Acronyms}

$\begin{array}{ll}\text { AD } & \text { anti-dumping } \\ \text { ARC } & \text { antireflective coatings } \\ \text { BoM } & \text { bill of materials } \\ \text { CapEx } & \text { capital expenditures } \\ \text { CdTe } & \text { cadmium telluride } \\ \text { c-Si } & \text { crystalline silicon } \\ \text { CVD } & \text { countervailing duties } \\ \text { DC } & \text { direct current } \\ \text { EVA } & \text { ethylene vinyl acetate } \\ \text { GW } & \text { gigawatt } \\ \text { H } & \text { half (e.g., H1 = first half) } \\ \text { half-cut cell } & \text { c-Si cells that have been cut in half before module assembly, resulting in a } \\ & \text { module with twice the amount of cell strings and reduced ohmic losses } \\ \text { HTS } & \text { Harmonized Tariff Schedule } \\ \text { ITC } & \text { investment tax credit } \\ \text { kg } & \text { kilogram } \\ \text { mono-PERC } & \text { monocrystalline passivated emitter and rear cell } \\ \text { MSP } & \text { minimum sustainable price } \\ \text { MW } & \text { megawatt } \\ \text { MWT } & \text { metal wrap through } \\ \text { NREL } & \text { National Renewable Energy Laboratory } \\ \text { OEM } & \text { original equipment manufacturer } \\ \text { PERC } & \text { passivated emitter and rear cell } \\ \text { PV } & \text { photovoltaic } \\ \text { R\&D } & \text { research and development } \\ \text { SE } & \text { Southeast } \\ \text { shingled cells } & \text { cells cut into several strips, which overlap each other slightly in so that the } \\ \text { SHJ } & \text { back of each shingle is connected to the front of the next } \\ \text { USD } & \text { silicon hetero-junction } \\ \text { USITC } & \text { United States dollars } \\ \text { USTR } & \text { United States International Trade Commission } \\ \text { W } & \text { U.S. Trade Representative } \\ \text { WTO } & \text { Watts } \\ & \text { World Trade Organization } \\ & \end{array}$




\section{Executive Summary}

Note: This report was originally submitted to the Department of Energy for publication in December 2019.

This report analyzes U.S. photovoltaic (PV) manufacturing announcements from 2017 through July 2019, presents eight case studies for U.S.-based PV manufacturers that made announcements during this period, and explores the potential impact of tariffs on the competitiveness of U.S. PV module manufacturing. The major findings are summarized below.

\section{U.S. PV Manufacturing Announcements}

From 2017 through July 2019, several manufacturers announced plans to expand U.S. domestic PV production capacity (Table ES-1). If all planned capacity expansions were successfully implemented, the United States would have a total of $9.6 \mathrm{GW} /$ year of module capacity (including crystalline-silicon [c-Si] and thin-film PV) and $1.8 \mathrm{GW} /$ year of c-Si cell capacity. However, as of July 2019, the expected capacity total includes 5.6 GW/year of c-Si PV module assembly capacity (including capacity existing before 2017, $0.9 \mathrm{GW} /$ year of module announcements that have been completed, and an expected $3.4 \mathrm{GW} /$ year that have initiated pilot production), 0.5 $\mathrm{GW} /$ year of c-Si cell production, and $2.1 \mathrm{GW} /$ year of thin-film module production. This corresponds to a total U.S. PV module capacity of $7.7 \mathrm{GW} /$ year. The U.S. demand for PV installations in the past few years has been approximately $10 \mathrm{GW} /$ year. Although $7.7 \mathrm{GW} /$ year of U.S. PV module production cannot completely supply this level of domestic demand, it would represent a significant increase over annual U.S. PV manufacturing production in the past decade.

Table ES-1. Historical and Projected U.S. PV Manufacturing Capacity Based on Company Announcements

\begin{tabular}{|c|c|c|c|}
\hline & Historical & $\begin{array}{c}\text { Projection: } \\
\text { best-case scenario }\end{array}$ & $\begin{array}{l}\text { Projection: } \\
\text { expected outcome }\end{array}$ \\
\hline & $\begin{array}{c}\text { Existing prior to } \\
\text { announcements } \\
\text { (GW/year) }\end{array}$ & $\begin{array}{c}\text { Includes all } \\
\text { announcements and } \\
\text { existing capacity } \\
\text { (GW/year) }\end{array}$ & $\begin{array}{l}\text { Based on existing } \\
\text { and pilot production } \\
\text { as of July } 2019 \\
\text { (GW/year) }\end{array}$ \\
\hline U.S. c-Si Cell Capacity & 0.2 & 1.8 & 0.5 \\
\hline U.S. c-Si Module Capacity & 1.3 & 7.5 & 5.6 \\
\hline U.S. Thin-Film Module Capacity & 0.9 & 2.1 & 2.1 \\
\hline Total Module Capacity & 2.2 & 9.6 & 7.7 \\
\hline
\end{tabular}

The largest fraction of planned capacity expansions was from companies headquartered in the United States (50\%), while the second largest was from South Korean companies (29\%).

Companies with no previous physical U.S. manufacturing, research and development, or installer facilities were most common ( $45 \%$ by capacity), followed closely by companies that already had U.S. PV manufacturing facilities (41\%). Monocrystalline passivated emitter and rear cell (monoPERC) modules were the most common target product (41\%). Greenfield facilities accounted for the largest share of capacity $(39 \%$, ) which included only two facilities. The second-largest share 
of capacity (34\%) used existing vacant buildings in the interest of time, to gain the largest possible benefits from the Section 201 tariffs.
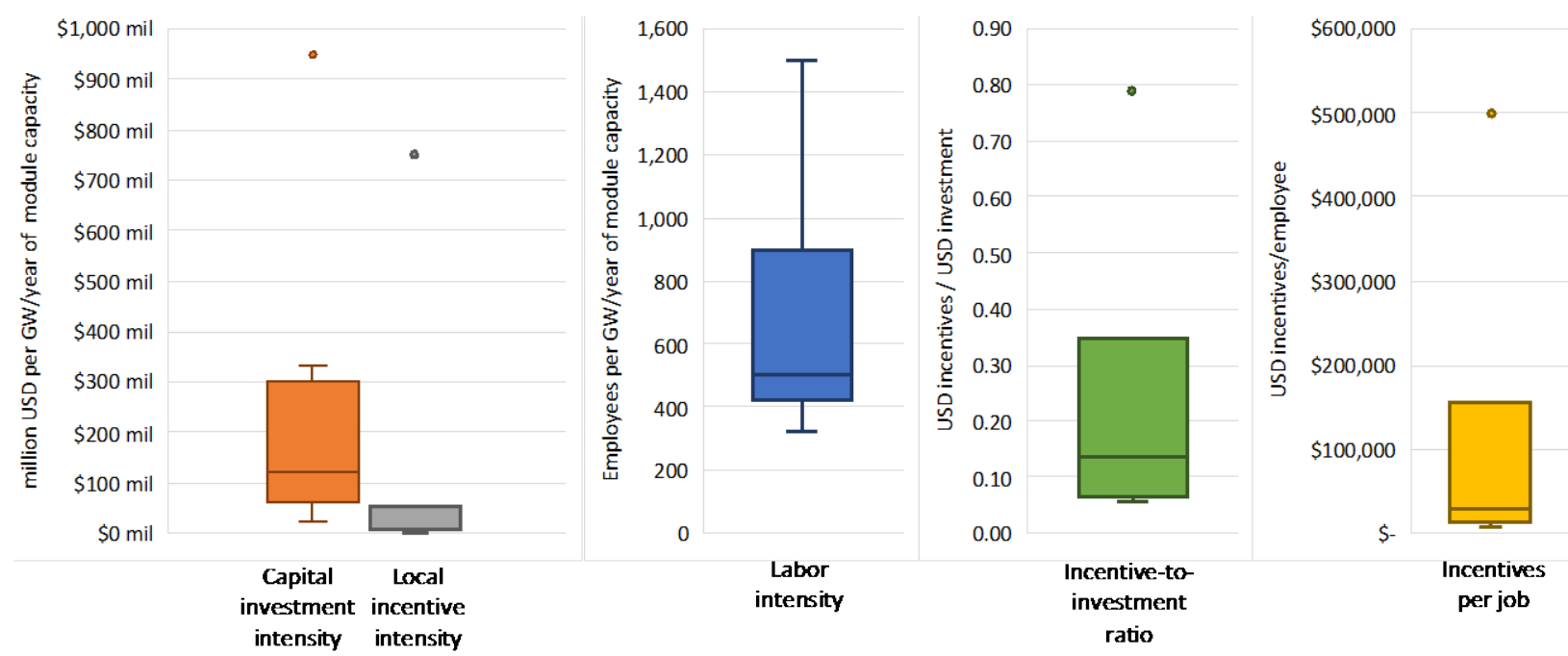

Figure ES-1. CapEx and local incentive intensity per GW/year of planned capacity, employees per GW/year, and incentives per CapEx investment and per job

The boxes represent the first and third quartiles centered around the median, and the whiskers represent the maximum and minimum values. Statistical outliers (more than 1.5 times the third quartile) are shown separately.

Figure ES-1 shows summary statistics related to the labor, capital expenditures (CapEx), and incentive intensities. Both the number of employees and the CapEx per GW/year of planned module capacity appear to correlate negatively with plant size. These intensities range from 300 to 1,500 employees per GW/year and \$20 million to \$330 million of CapEx per GW/year (for some sites, CapEx intensities also apply to cell production at the same location). The remaining three statistics have a maximum value that is smaller than the corresponding third quartile: the value of local incentives offered to expanding companies corresponded to $\$ 1-\$ 55$ million of incentives per GW/year of module capacity, \$0.06-\$0.20 of incentives per dollar of CapEx, and $\$ 8,000-\$ 40,000$ of incentives per employee.

\section{U.S. PV Manufacturing Case Studies}

In the first half of 2019, we interviewed representatives at eight of the firms that announced plans for expanded U.S. production since early 2017. The firms include Auxin Solar, which had an $8 \%$ share of U.S. module production capacity in 2017, First Solar (48\%), Hanwha Q Cells $(0 \%)$, JinkoSolar (0\%), LG (0\%), Silfab (9\%), Solaria (3\%), and SunPower (5\%). The proposed expansions of these eight firms represent $4.4 \mathrm{GW}$, which is $70 \%$ of all proposed expansions. The firms were selected to cover a range of sizes, locations, ownership structures, and technologies. The case studies highlight the importance of the following five factors in influencing firms' decisions to expand their U.S. PV production capacity:

- Proximity to demand. For most firms, a major motivation to locate manufacturing in the United States was the significant domestic U.S. demand for their technology through existing supply chains or specific supply contracts. Multiple firms also noted 
that demand for made- or assembled-in-USA products, including supply contracts with minimum domestic content requirements, was an important driver.

- Ability to move quickly. Most firms mentioned the desire to move quickly to maximize the benefits of the Section 201 tariffs. This included moving into existing structures, relocating existing equipment from other manufacturing sites, or purchasing entire existing solar facilities while upgrading the equipment and retaining the employees. Similarly, some firms also mentioned the ease and rapidity of facility acquisition and permitting as a deciding factor for selecting a locality. Some firms cited the time and investment necessary for cell-fabrication facilities as a major reason for the lack of much existing or planned U.S. cell capacity.

- Tariffs and other incentives. Most firms seemed supportive of the Section 201 tariffs, although they commonly expressed the belief that the cell import cap should be higher than $2.5 \mathrm{GW} /$ year. Most firms also said they located new capacity in existing facilities or buildings to reduce lead time and capitalize on the Section 201 tariffs as soon as possible. However, most firms stated that the Section $301^{1}$ tariffs offset at least some - if not all — of the U.S. manufacturing competitiveness provided by the Section 201 tariffs (both sets of tariffs are described fully in Section 2 of this report). Because U.S. supply chains do not exist for most PV module components, or do not exist at a scale to supply the PV module industry, importing components subject to Section 301 tariffs was difficult to avoid. Furthermore, uncertainty regarding the scheduled increase of the Section 301 tariff rate hindered the sourcing of components affected by the tariffs; supplier quotes include tariff costs, so suppliers required an extra payment in case of a tariff increase. Most firms mentioned that the 2018 decrease in the U.S. corporate tax rate made a stronger financial case for adding U.S. manufacturing, although most also said they were already exploring the option before the tax rate reduction was anticipated. The majority of firms indicated that local incentives (such as tax benefits or labor availability) were considered in their selection of a manufacturing site, but many indicated that similar local financial incentives were available at all locations under consideration.

- Access to capital. Several firms cited access to capital as a primary challenge when expanding U.S. manufacturing. Larger firms often financed their expansions internally, whereas smaller firms had more challenges accessing capital.

- Competition with scale. Some smaller firms expressed concern that larger firms may not need their U.S. facilities to be profitable, which would limit the smaller firms' ability to compete and influenced their decision to expand in the United States. Similarly, many firms communicated that competing with or avoiding the need to import Asian PV-components (e.g., cells, modules, cover glass) is challenging owing to the larger scale of Asian manufacturers and their lower reliance on profit margins.

\section{PV Tariff Analysis}

Several U.S. tariffs affect the economics of PV cells, modules, and bill of materials (BoM) items, some of which are applicable to a long list of countries and others applicable only to China or

\footnotetext{
${ }^{1}$ These statements were made by firms in March and April of 2019, when the Section 301 tariffs were $25 \%$ for Lists 1 and 2, and $10 \%$ for List 3 . List 4 did not exist yet. Rates have changed since then and are partially documented in Section 2.
} 
Taiwan. We analyze how the tariffs (described in Section 2) interact to affect the prices of c-Si modules sourced under various assumptions about domestic and imported components and assembly. We estimate module prices using a bottom-up cost model under a range of baseline scenarios featuring U.S.-assembled modules with Southeast Asian cells (not from China or Taiwan, which have had cell tariffs since 2015). The cost model assumes a gross margin of 28\% and operating margin of $15 \%$. We assume the BoM items can be sourced from countries other than China at the same price as Chinese BoM, but this may not be a realistic assumption for all components. If all BoM items are sourced from countries other than China, baseline module prices are $\$ 0.37 / \mathrm{W}$ (below the $2.5 \mathrm{GW} /$ year cell cap for Section 201 ) to $\$ 0.42 / \mathrm{W}$ (above the 2.5 $\mathrm{GW} /$ year cell cap). If all BoM items are sourced from China, the module price in the baseline U.S.-assembly scenarios can reach up to $\$ 0.60 / \mathrm{W}$.

Imported module prices are lower than or within the range of the U.S.-assembled baseline prices under some conditions. Importing bifacial modules from Southeast Asia would have been the lowest-priced alternative at $\$ 0.37 / \mathrm{W}$, because bifacial modules were exempted from the Section 201 tariffs, and importing finished modules avoids the Section 301 tariffs. Importing Southeast Asian modules that have Southeast Asian cells yields a price of $\$ 0.46 / \mathrm{W}$, and importing Chinese modules that have U.S. cells yields a price of $\$ 0.57 / \mathrm{W}$.

Module prices for select scenarios in mid-2019 are shown in Figure ES-2; more scenarios are detailed in Section 5. This figure shows mono-facial monocrystalline PERC modules. The first bar shows imported modules from Southeast Asia, and the four bars to the right show scenarios for U.S. module assembly relying on imported cells. The first two U.S. module assembly scenarios assume that cells are imported under the $2.5 \mathrm{GW} /$ year cap. The first scenario assumes no BoM items are sourced from China, while the second assumes all BoM items are sourced from China. The second pair of scenarios assumes that cells are imported above the $2.5 \mathrm{GW} / \mathrm{year}$ cap. The third bar in this section assumes no BoM items are sourced from China, while the fourth assumes all BoM items are sourced from China. 


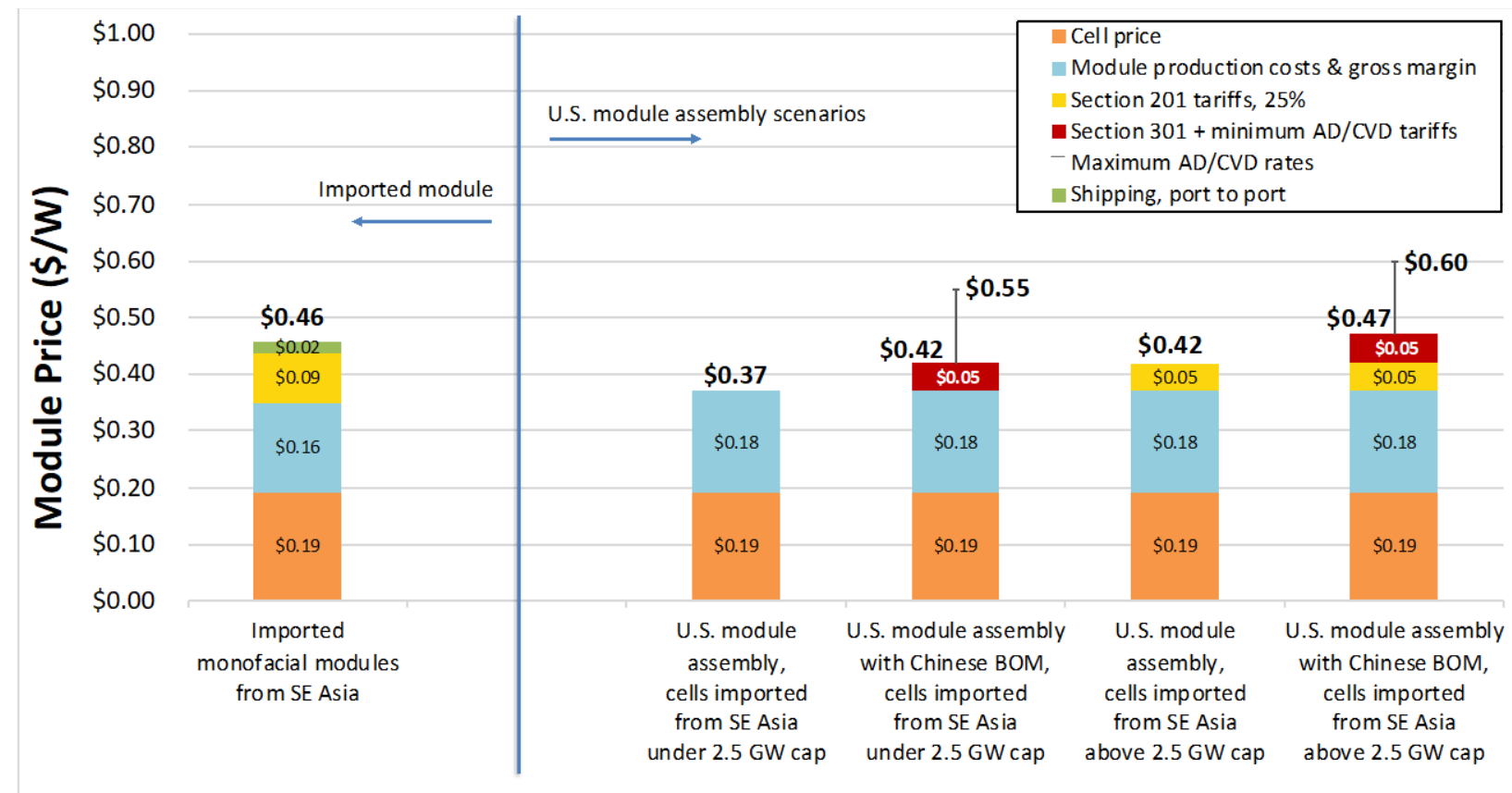

Figure ES-2. PERC module prices under various manufacturing scenarios and tariff conditions, mid-2019

These results suggest that U.S. tariff policy in 2019 may encourage U.S. assembly of monofacial c-Si modules if the $2.5 \mathrm{GW} /$ year cell import cap is not reached and Chinese BoM imports are negligible. However, some imported module options may offer the lowest prices if the 2.5 $\mathrm{GW} /$ year cell import cap is reached and/or U.S. module manufacturers must rely on significant Chinese BoM content.

Our research indicates the $2.5 \mathrm{GW} /$ year cell cap may be exceeded in 2019 or following years if U.S. capacity utilization rates are high, and that U.S. module manufacturers likely will need to use at least some Chinese BoM content, which helped us define the scenarios selected for analysis shown in Figure ES-2. If all U.S. module plants that were in pilot production as of July 2019 reach full capacity, up to $5.6 \mathrm{GW} /$ year of cells would need to be imported each yeartherefore, up to about $3 \mathrm{GW} /$ year of cells would be subject to the existing Section 201 cell tariffs. If all U.S. plans for c-Si cell and module capacity announced from 2017 through July 2019 are fully realized, the need for imported cells would increase to $5.7 \mathrm{GW} /$ year, and thus up to 3.2/year GW of cells might become subject to the existing Section 201 cell tariffs. With regard to Chinese BoM content, U.S. module manufacturers have stated that U.S. supply chains do not exist (or do not exist at a sufficient scale) for most BoM items, which makes them at least partially reliant on Chinese BoM items and thus subject to Section 301 tariffs. 


\section{Table of Contents}

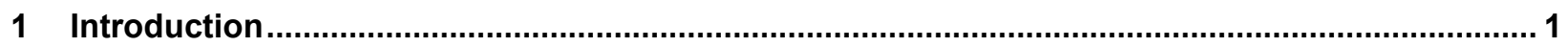

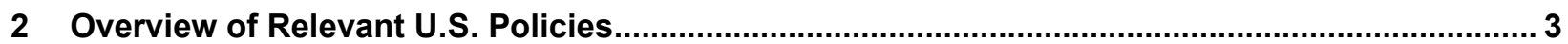

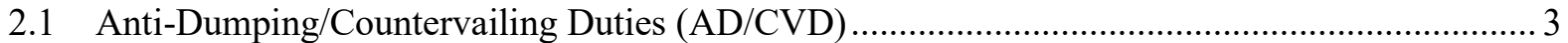

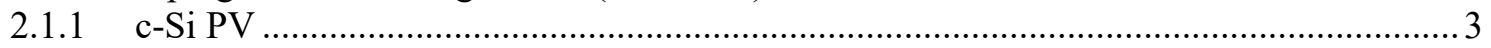

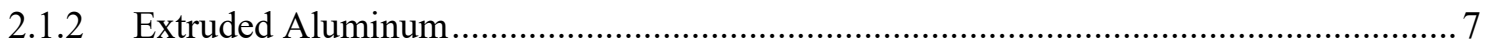

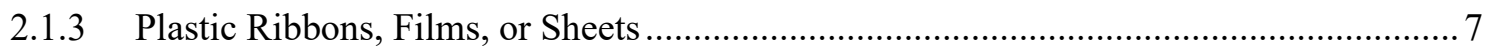

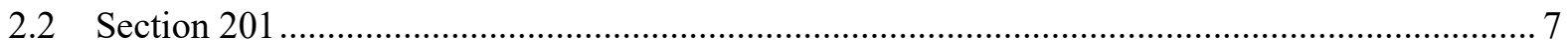

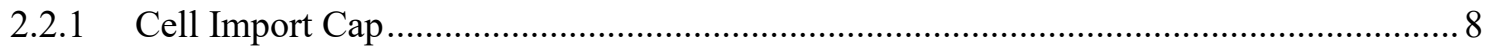

2.2.2 Cumulative Tariffs with AD/CVD ............................................................ 9

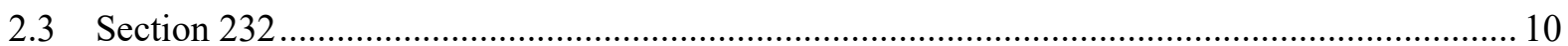

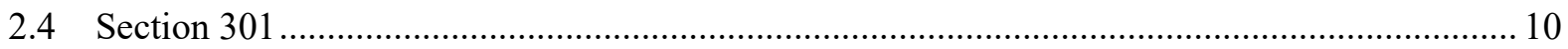

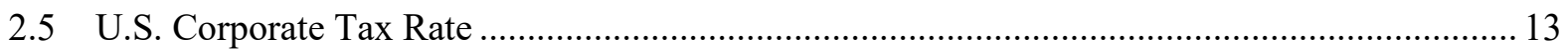

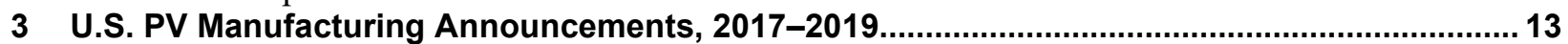

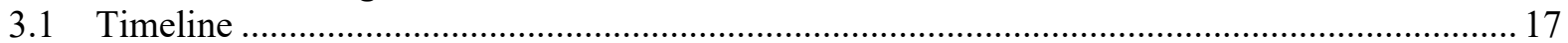

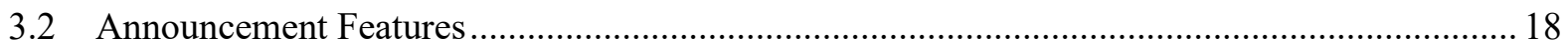

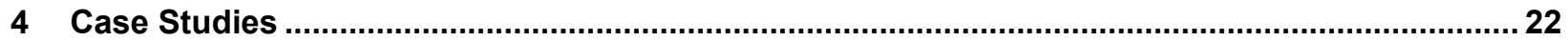

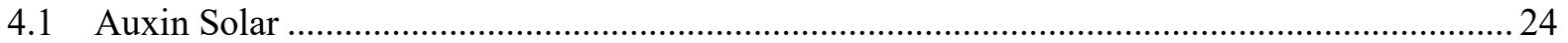

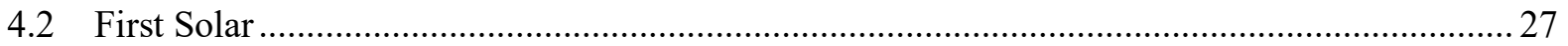

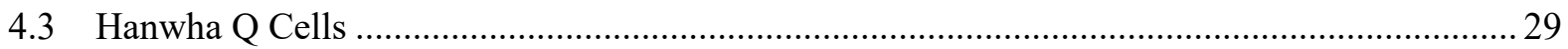

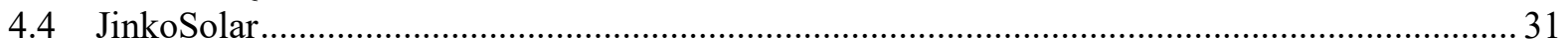

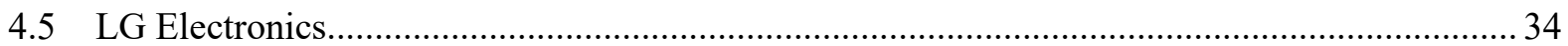

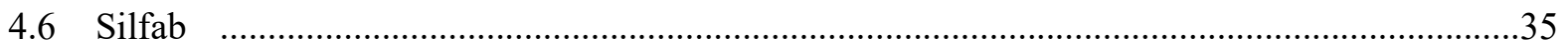

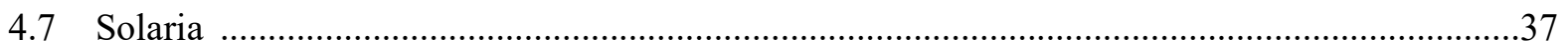

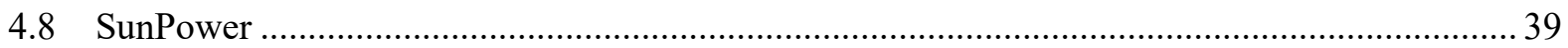

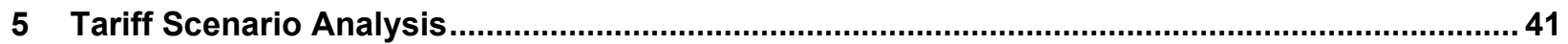

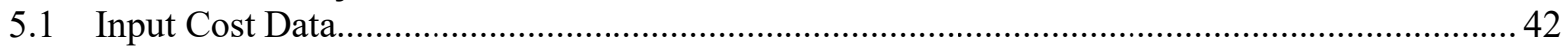

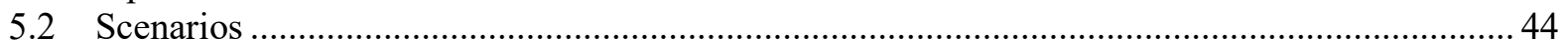

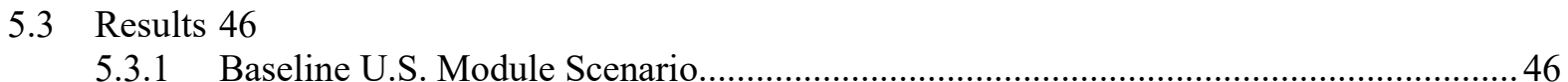

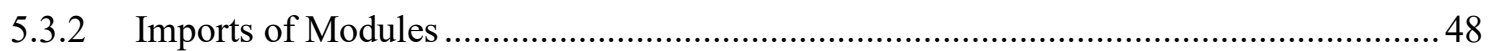

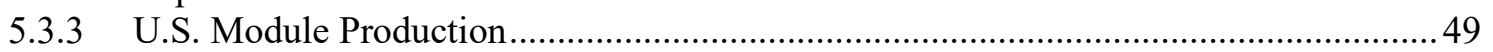

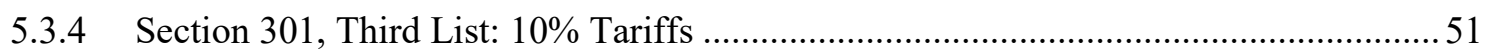

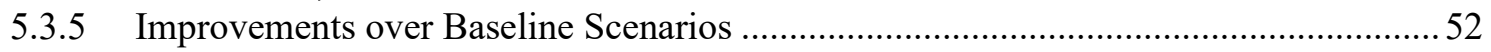

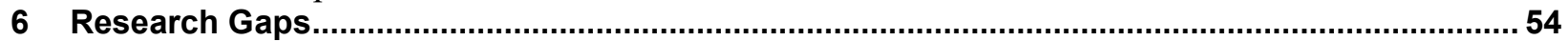

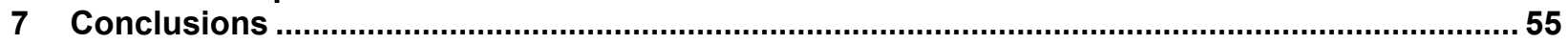

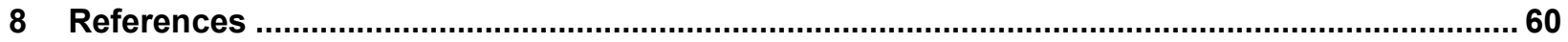

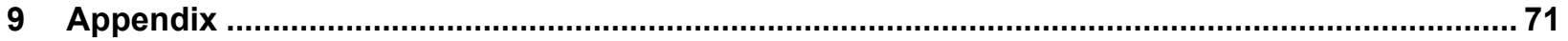




\section{List of Figures}

Figure 1. Annual historical and projected (P) U.S. PV deployment, 2010-2022 (BNEF 2018), (Goldman Sachs 2019), (Wood Mackenzie Power \& Renewables and SEIA 2019b) ............................. 2

Figure 2. Annual U.S. PV manufacturing, H2 2015 - H1 2019 (GTM Research and SEIA 2016, 2017, 2018, Wood Mackenzie Power \& Renewables and SEIA 2019a) ........................................ 3

Figure 3. Combined minimum duties on Chinese modules using Chinese cells, compared to China's annual percentage of all PV module imports into the United States.................................... 7

Figure 4. Existing U.S. PV manufacturing capacity in 2016, and expansions announced January 2017 to

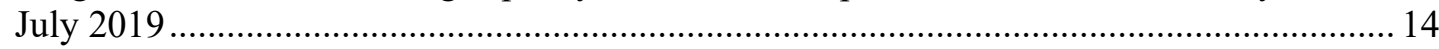

Figure 5. Timeline of U.S. PV manufacturing capacity-expansion announcements ............................... 17 Figure 6. Announcement analysis quantified by GW/year of added capacity for a) existing U.S. presence, b) company nationality, c) cell sourcing, d) cell architecture, e) facility type, and f) target market

Figure 7. a) Employees per GW/year of module capacity as a function of plant size, and b) CapEx per $\mathrm{GW} /$ year of module capacity as a function of plant size.

Figure 8. a) Local financial incentives per GW/year of module capacity as a function of plant size, and b) local financial incentives per USD CapEx as a function of plant size ................................. 21

Figure 9. Local financial incentives per employee as a function of plant size...................................... 22

Figure 10. Mono-PERC cell and module price assumptions by production region, without tariffs ........... 43

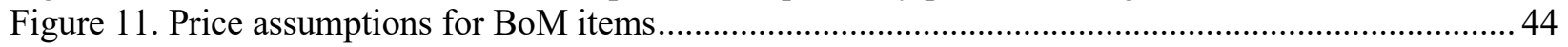

Figure 12. Sourcing of annual U.S. PV module shipments by country, 2006-2017 .............................. 46

Figure 13. Module prices for U.S. module assembly, including individual tariffs on imported cells and

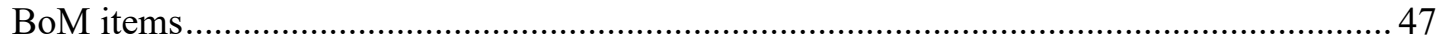

Figure 14. Imported module prices including tariffs on modules imported from China and Southeast Asia,

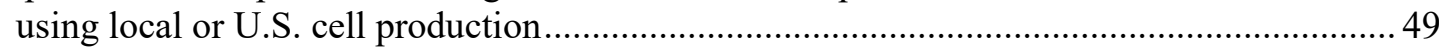

Figure 15. U.S.-assembled module prices as a function of cell origins and Section 201 cell cap (2.5 GW/year) status, using BoM items from Chinese suppliers ............................................. 50

Figure 16. U.S.-assembled module prices as a function of cell origins and Section 201 cell cap (2.5 GW/year) status, using BoM items from non-Chinese suppliers ........................................ 51

Figure 17. Section 301 tariffs on BoM items when the third list is set to $10 \%$..................................... 52

Figure 18. PERC module prices under various manufacturing scenarios and tariff conditions, mid-2019 59

\section{List of Tables}

Table 1. Historical and Projected U.S. PV Manufacturing Capacity Based on Company Announcements. 1

Table 2. Summary of AD/CVD Rates on Affected Products as of July 2019 ........................................... 4

Table 3. Timeline of the 2012 PV AD/CVD Actions Through July 2019 ................................................. 4

Table 4. Timeline of the 2015 PV AD/CVD Actions Through July 2019............................................. 6

Table 5. Projected Cell Imports Based on Current U.S. PV Manufacturing Capacity and Company

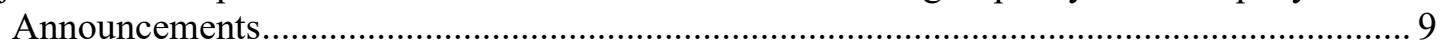

Table 6. Compound AD/CVD and Section 201 Tariff Rates for c-Si PV Products ................................ 10

Table 7. Compounded Tariff Rates for c-Si PV from China from Section 301 List 1, Section 201, and

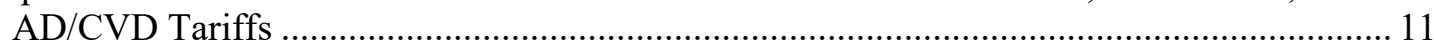

Table 8. PV Module and BoM Items Included in Section 301 Tariffs and Their Respective HTS Codes and Duty Rates if Sourced from China ......................................................................... 12

Table 9. Sourcing Configurations for Tariff Analysis (baseline U.S. module production scenarios

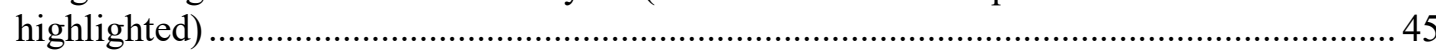

Table 10. Tariff Scenarios with Module Prices Lower than or Equivalent to Baseline Module Prices...... 53 
Table 11. Historical and Projected U.S. PV Manufacturing Capacity Based on Company Announcements .56

Table 12. 2017-2019 Announcements of Plans to Add U.S. PV Manufacturing Capacity: by Size, Type, and Status as of July 2019.

Table 13. 2017-2019 Announcements of Plans to Add U.S. PV Manufacturing Capacity by U.S. Presence, Country of Origin, Cell Sourcing, Cell Architecture, Facility Type, and Target Markets. 72

Table 14. 2017-2019 Announcements of Plans to Add U.S. PV Manufacturing Capacity: Jobs Data and References. 73

Table 15. 2017-2019 Announcements of Plans to Add U.S. PV Manufacturing Capacity: CapEx Data and References. 74

Table 16. 2017-2019 Announcements of Plans to Add U.S. PV Manufacturing Capacity: Incentive Data and References 75 


\section{Introduction}

Since 2011, multiple federal efforts (via Executive Orders) have targeted establishing a more competitive market for domestic photovoltaic (PV) manufacturing in the United States. In 2012 and 2015, the United States imposed anti-dumping and countervailing duties (AD/CVD) on Chinese PV manufacturers (U.S. International Trade Administration 2012a, 2015a). During the following years, U.S. imports of PV products shifted from China to Taiwan, South Korea, and Malaysia. In 2018, tariffs (colloquially referred to as "Section 201 tariffs") were levied against imports of crystalline-silicon (c-Si) PV cells and modules from an extensive list of countries (U.S. Customs and Border Protection 2018b). Tariffs (colloquially referred to as "Section 232 tariffs") were also levied against imports of aluminum and steel in 2018, which are used in the construction of PV manufacturing facilities, PV module assembly, and PV racking (U.S. Customs and Border Protection 2018d). Greater detail on these tariff actions can be found in the following section (Section 2: Overview of Relevant U.S. Policies).

In the summer of 2018, tariffs on a larger variety of items imported from China were also introduced (colloquially referred to as "Section 301 tariffs"), which include most of the components needed to manufacture c-Si PV modules: cover glass, aluminum frames, junction boxes, and other items (U.S. Customs and Border Protection 2018e). Additional AD/CVD tariffs apply to other specific items from China that often constitute module components.

From 2017 through July 2019, several manufacturers announced plans to expand U.S. domestic PV manufacturing capacity, which are reported in aggregate in Table 1 . The potential expanded capacity included roughly $7.5 \mathrm{GW} /$ year of additional module capacity (including $1.2 \mathrm{GW} / \mathrm{year}$ of cadmium telluride [CdTe] thin-film module production) and up to $1.6 \mathrm{GW} /$ year of additional c-Si cell capacity (Smith and Margolis 2019). If all planned capacity expansions were successfully implemented, the United States would have a total of $9.6 \mathrm{GW} /$ year of module capacity (including c-Si and thin-film PV) and $1.8 \mathrm{GW} /$ year of c-Si cell capacity.

Table 1. Historical and Projected U.S. PV Manufacturing Capacity Based on Company Announcements

\begin{tabular}{|c|c|c|c|}
\hline & Historical & $\begin{array}{c}\text { Projection: } \\
\text { best-case scenario }\end{array}$ & $\begin{array}{l}\text { Projection: } \\
\text { expected outcome }\end{array}$ \\
\hline & $\begin{array}{c}\text { Existing prior to } \\
\text { announcements } \\
\text { (GW/year) }\end{array}$ & $\begin{array}{c}\text { Totals including all } \\
\text { announcements and } \\
\text { existing capacity } \\
\text { (GW/year) }\end{array}$ & $\begin{array}{c}\text { Based on existing and } \\
\text { pilot production } \\
\text { as of July } 2019 \\
\text { (GW/year) }\end{array}$ \\
\hline U.S. c-Si Cell Capacity & 0.2 & 1.8 & 0.5 \\
\hline U.S. c-Si Module Capacity & 1.3 & 7.5 & 5.6 \\
\hline U.S. Thin-Film Module Capacity & 0.9 & 2.1 & 2.1 \\
\hline Total Module Capacity & 2.2 & 9.6 & 7.7 \\
\hline
\end{tabular}

However, it appears the actual totals that completed or initiated pilot production as of July 2019 were 5.5 GW/year of additional PV module production and $0.3 \mathrm{GW} /$ year of additional c-Si cell 
production (see Table 12 in the appendix for the status of each site). ${ }^{2}$ This corresponds to a total U.S. PV module capacity of $7.7 \mathrm{GW} / \mathrm{year}$. The U.S. demand for PV installations in the past few years has been approximately $10 \mathrm{GW} /$ year (Figure 1). Although $7.7 \mathrm{GW} /$ year of U.S. PV module production cannot completely supply this level of domestic demand, it would represent a significant increase over annual U.S. PV manufacturing over the past 4 years (Figure 2).

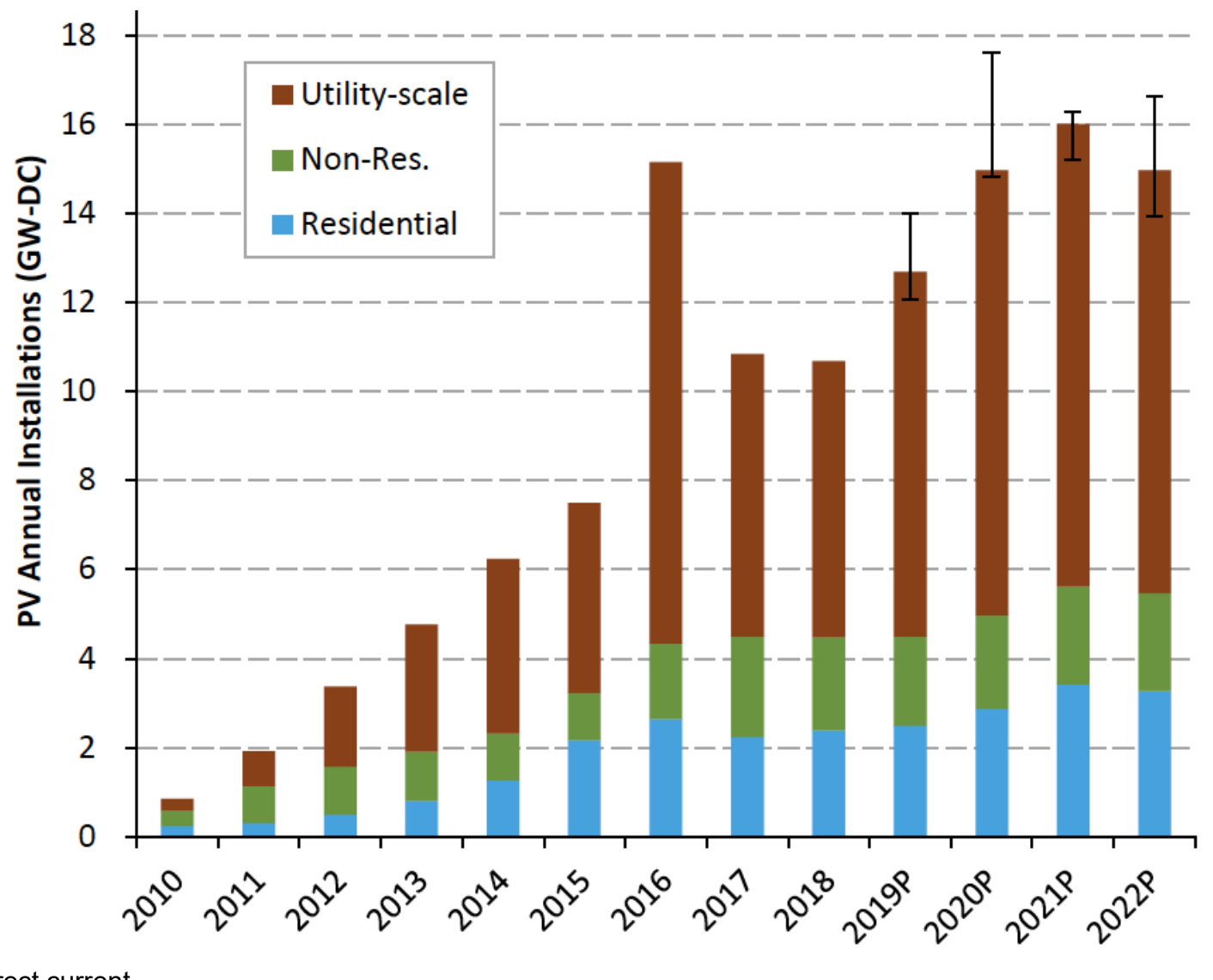

$\mathrm{DC}=$ direct current

Figure 1. Annual historical and projected (P) U.S. PV deployment, 2010-2022 (BNEF 2018), (Goldman Sachs 2019), (Wood Mackenzie Power \& Renewables and SEIA 2019b)

This report evaluates the conditions that may support successful U.S. PV manufacturing expansions in the context of product technology, tariffs, corporate tax rates, and local or state incentives. This analysis seeks to provide insights on factors or conditions that may impact the effectiveness of Executive Orders or related measures to support the U.S. PV industry and the ability of the U.S. PV industry to install domestically manufactured PV products.

\footnotetext{
${ }^{2}$ This report benchmarks the trade situation and company information as of July 2019. However, owing to the rapidly changing nature of the PV industry and market, readers will need to search beyond this report for the most up-to-date information. See the quarterly industry updates from the Solar Technology Cost Analysis team at NREL at https://www.energy.gov/eere/solar/quarterly-solar-industry-update, or similar such sources.
} 


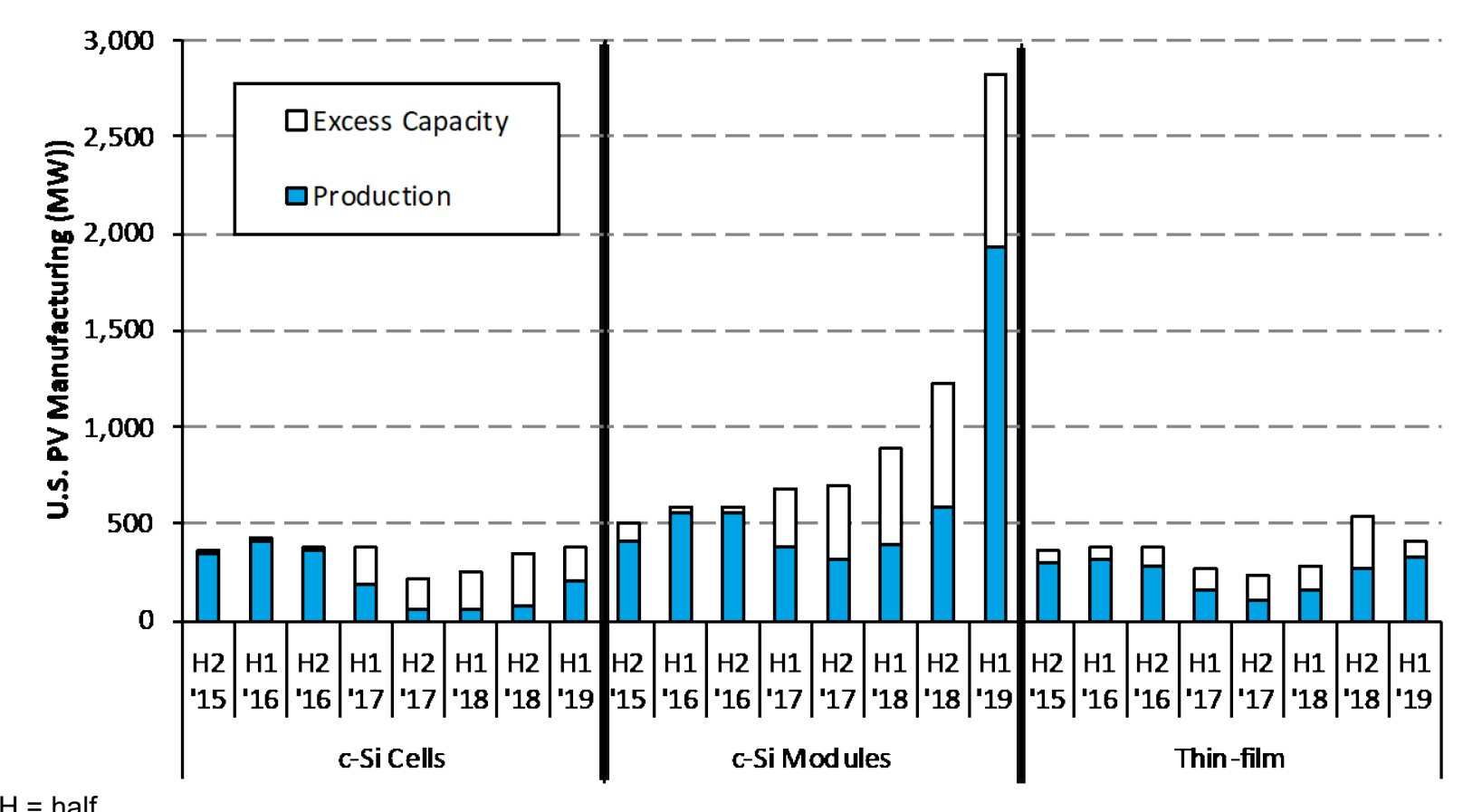

Figure 2. Annual U.S. PV manufacturing, H2 2015 - H1 2019 (GTM Research and SEIA 2016, 2017, 2018; Wood Mackenzie Power \& Renewables and SEIA 2019a)

\section{Overview of Relevant U.S. Policies}

In this section, we review trade policies that affect the PV industry, primarily in the form of tariffs. The impact of these policies varies significantly depending on the component being imported and the country of origin. We review the range of existing policies as of July 2019.

\subsection{Anti-Dumping/Countervailing Duties (AD/CVD)}

\subsection{1 c-Si PV}

In 2011, U.S. PV manufacturers filed a complaint to the United States International Trade Commission (USITC) and the U.S. Department of Commerce, based on a concern that Chinese companies were selling c-Si modules below cost to gain market share and receiving unfair subsidies from the Chinese government. This resulted in AD/CVD tariffs placed on modules with Chinese-made c-Si cells in 2012 (U.S. International Trade Administration 2012a, b). AD tariffs are punitive tariffs placed on countries that sell below cost to gain market share, whereas CVD are punitive tariffs placed on countries that receive government subsidies believed to be unfair. This initial round of AD/CVD tariffs in 2012 led to some Chinese companies shipping wafers to Taiwan which then shipped Taiwanese cells back to China, in order to export Chinese modules containing cells that were claimed to be Taiwanese. As a result, a second complaint from U.S.-based PV manufacturers led to wider tariffs on Chinese panels and Taiwanese cells, enacted in 2015 (U.S. International Trade Administration 2015a). Neither the 2012 nor 2015 $\mathrm{AD} / \mathrm{CVD}$ tariffs have an expiry date. The magnitude of these tariffs differ across companies, based on the extent they were involved in the unfair practices as determined by the USITC. Furthermore, $\mathrm{AD} / \mathrm{CVD}$ rates are reviewed annually and revised retroactively, so it is possible that companies may either be reimbursed or end up paying additional tariffs on goods imported 
during previous periods. A summary of the different rates and affected products is presented in Table 2. The rates in each row are explicitly defined as not applicable to products that are already affected by previous c-Si PV AD/CVD measures. For example, modules made in China using Taiwanese cells are only subject to Chinese module AD/CVD rates and not the rates for any module made using Taiwanese cells. Likewise, the 2015 rates on Chinese modules do not apply to Chinese modules made with Chinese cells, because these would already be subject to the 2012 rates. Broad timelines of policy actions relevant to these AD/CVD rates are presented in Table 3 and Table 4.

Table 2. Summary of AD/CVD Rates on Affected Products as of July 2019

\begin{tabular}{|c|c|c|c|c|}
\hline & AD & CVD & $\begin{array}{l}\text { Minimum to } \\
\text { maximum total } \\
\text { (for a given } \\
\text { company) }\end{array}$ & Reference \\
\hline $\begin{array}{l}\text { Chinese cells, or } \\
\text { any module with } \\
\text { Chinese cells }\end{array}$ & $\begin{array}{c}2.67 \% \\
\text { to } \\
238.95 \%\end{array}$ & 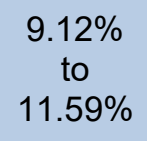 & $\begin{array}{c}13.31 \% \\
\text { to } \\
249.95 \%\end{array}$ & See Table 3 \\
\hline $\begin{array}{l}\text { Chinese modules } \\
\text { with any cells }\end{array}$ & $\begin{array}{c}9.61 \% \\
\text { to } \\
151.98 \%\end{array}$ & $\begin{array}{l}27.65 \% \\
\text { to } \\
94.83 \%\end{array}$ & $\begin{array}{c}37.26 \% \\
\text { to } \\
185.56 \%\end{array}$ & See Table 4 \\
\hline $\begin{array}{l}\text { Taiwanese cells, } \\
\text { or any module } \\
\text { with Taiwanese } \\
\text { cells }\end{array}$ & $\begin{array}{l}1.00 \% \\
\text { to } \\
19.5 \%\end{array}$ & & $\begin{array}{c}1.00 \% \\
\text { to } \\
19.5 \%\end{array}$ & See Table 4 \\
\hline
\end{tabular}

Table 3. Timeline of the 2012 PV AD/CVD Actions Through July $2019^{3}$

\begin{tabular}{|c|c|c|}
\hline $\begin{array}{l}\text { Month } \\
\& \text { Year }\end{array}$ & Action & Reference \\
\hline 2012 & $\begin{array}{l}\text { The United States placed AD/CVD rates on Chinese c-Si cells or } \\
\text { modules with Chinese-made c-Si cells. } \\
\text { - AD rates: } 18.32 \% \text { to } 249.96 \% \\
\text { - CVD rates: } 14.78 \% \text { to } 15.97 \%\end{array}$ & $\begin{array}{l}\text { (U.S. International } \\
\text { Trade Administration } \\
\text { 2012a, b) }\end{array}$ \\
\hline $\begin{array}{r}\text { May } \\
2012\end{array}$ & $\begin{array}{l}\text { The } 2012 \text { CVD rates were challenged by China before the World } \\
\text { Trade Organization (WTO) later in } 2012 \text {. }\end{array}$ & $\begin{array}{l}\text { (World Trade } \\
\text { Organization 2019) }\end{array}$ \\
\hline 2014 & $\begin{array}{l}\text { China placed } A D / C V D \text { rates on U.S. polysilicon (averaging } 55 \% \text { ), } \\
\text { which many view as a retaliatory measure. Some analysis of the } \\
\text { effects of these policies on the PV industry has been conducted in } \\
\text { reference at right. }\end{array}$ & (Sandor et al. 2018) \\
\hline $\begin{array}{l}\text { July } \\
2015\end{array}$ & $\begin{array}{l}\text { The U.S. review of } 2012 \text { AD rates through } 2013 \text { was published. } \\
\text { - New rates: } 0.79 \% \text { to } 238.95 \%\end{array}$ & $\begin{array}{l}\text { (U.S. International } \\
\text { Trade Administration } \\
\text { 2015b) }\end{array}$ \\
\hline
\end{tabular}

\footnotetext{
${ }^{3}$ In August 2019, the U.S. review of the 2016 calendar year for the CVD rates originally administrated in 2012 was completed, and rates were adjusted such that the range became $9.7 \%$ to $12.76 \%$ (U.S. International Trade Administration 2019i). However, this range is not used in the later analyses in this report.
} 


\begin{tabular}{|c|c|c|}
\hline $\begin{array}{l}\text { Month } \\
\text { \& Year }\end{array}$ & Action & Reference \\
\hline $\begin{array}{l}\text { July } \\
2015\end{array}$ & $\begin{array}{l}\text { The U.S. review of } 2012 \text { CVD rates for } 2012 \text { was published. } \\
\text { - New rates: } 15.43 \% \text { to } 23.28 \%\end{array}$ & $\begin{array}{l}\text { (U.S. International } \\
\text { Trade Administration } \\
\text { 2015c) }\end{array}$ \\
\hline $\begin{array}{r}\text { Oct } \\
2015\end{array}$ & $\begin{array}{l}\text { The WTO ruled that the United States must revise its } 2012 \text { CVD } \\
\text { rates by April } 2016 .\end{array}$ & $\begin{array}{l}\text { (World Trade } \\
\text { Organization 2019) }\end{array}$ \\
\hline $\begin{array}{r}\text { May } \\
2016\end{array}$ & $\begin{array}{l}\text { China requested a WTO compliance probe, alleging that the United } \\
\text { States had not revised its CVD rates yet. }\end{array}$ & $\begin{array}{l}\text { (World Trade } \\
\text { Organization 2019) }\end{array}$ \\
\hline $\begin{array}{l}\text { June } \\
2016\end{array}$ & $\begin{array}{l}\text { The U.S. review of } 2012 \text { AD rates for } 2014 \text { was published. } \\
\text { - New rates: } 6.12 \% \text { to } 238.95 \%\end{array}$ & $\begin{array}{l}\text { (U.S. International } \\
\text { Trade Administration } \\
\text { 2016a) }\end{array}$ \\
\hline $\begin{array}{l}\text { July } \\
2016\end{array}$ & $\begin{array}{l}\text { The U.S. review of } 2012 \text { CVD rates for } 2013 \text { was published. } \\
\text { - Range was unaltered }\end{array}$ & $\begin{array}{l}\text { (U.S. International } \\
\text { Trade Administration } \\
\text { 2016b) }\end{array}$ \\
\hline $\begin{array}{l}\text { June } \\
2017\end{array}$ & $\begin{array}{l}\text { The U.S. review of } 2012 \text { AD rates for } 2015 \text { was published. } \\
\text { - New rates: } 4.66 \% \text { to } 238.95 \%\end{array}$ & $\begin{array}{l}\text { (U.S. International } \\
\text { Trade Administration } \\
\text { 2017g) }\end{array}$ \\
\hline $\begin{array}{r}\text { Oct } \\
2017\end{array}$ & $\begin{array}{l}\text { The U.S. review of } 2012 \text { CVD rates for } 2014 \text { was published. } \\
\text { - New rates: } 17.14 \% \text { to } 18.16 \%\end{array}$ & $\begin{array}{l}\text { (U.S. International } \\
\text { Trade Administration } \\
\text { 2017f) }\end{array}$ \\
\hline $\begin{array}{r}\text { July } \\
2018\end{array}$ & $\begin{array}{l}\text { The U.S. review of } 2012 \text { CVD rates for } 2015 \text { was published. } \\
\text { - New rates: } 11.39 \% \text { to } 14.34 \%\end{array}$ & $\begin{array}{l}\text { (U.S. International } \\
\text { Trade Administration } \\
\text { 2018e) }\end{array}$ \\
\hline $\begin{array}{r}\text { July } \\
2018\end{array}$ & $\begin{array}{l}\text { The U.S. review of } 2012 \text { AD rates for } 2016 \text { was published. } \\
\text { - New rates: } 15.85 \% \text { to } 238.95 \%\end{array}$ & $\begin{array}{l}\text { (U.S. International } \\
\text { Trade Administration } \\
\text { 2018d) }\end{array}$ \\
\hline $\begin{array}{r}\text { Oct } \\
2018\end{array}$ & $\begin{array}{l}\text { The United States revised its } 2012 \text { CVD rates for the } 2015 \text { calendar } \\
\text { year to fix a previously unnoticed error. } \\
\text { - Retroactive } 2012 \text { CVD rates: } 9.12 \% \text { to } 11.59 \%\end{array}$ & $\begin{array}{l}\text { (U.S. International } \\
\text { Trade Administration } \\
\text { 2018c) }\end{array}$ \\
\hline $\begin{array}{r}\text { Early } \\
\text { July } \\
2019\end{array}$ & $\begin{array}{l}\text { The WTO upheld its previous ruling on the } 2012 \text { CVD rates and } \\
\text { ruled that China was now permitted to enact retaliatory measures. }\end{array}$ & (Rojo Martín 2019) \\
\hline $\begin{array}{l}\text { Late } \\
\text { July } \\
2019\end{array}$ & $\begin{array}{l}\text { The U.S. review of } 2012 \text { AD rates for } 2017 \text { was published. } \\
\text { - New rates: } 2.67 \% \text { to } 238.95 \%\end{array}$ & $\begin{array}{c}\text { (U.S. International } \\
\text { Trade Administration } \\
\text { 2019h) }\end{array}$ \\
\hline
\end{tabular}


Table 4. Timeline of the 2015 PV AD/CVD Actions Through July $2019^{4}$

\begin{tabular}{|c|c|c|}
\hline $\begin{array}{l}\text { Month } \\
\& \text { Year }\end{array}$ & Action & Reference \\
\hline $\begin{array}{r}\text { Feb } \\
2015\end{array}$ & $\begin{array}{l}\text { The United States implemented AD/CVD rates on Chinese modules } \\
\text { and Taiwanese cells. } \\
\text { - China AD rates: } 26.71 \% \text { to } 165.04 \% \\
\text { - China CVD rates: } 27.64 \% \text { to } 49.79 \% \\
\text { - Taiwan AD rates: } 11.45 \% \text { to } 27.55 \%\end{array}$ & $\begin{array}{l}\text { (U.S. International } \\
\text { Trade Administration } \\
\text { 2015a) } \\
\text { (U.S. Department of } \\
\text { Commerce 2015) }\end{array}$ \\
\hline $\begin{array}{l}\text { July } \\
2017\end{array}$ & $\begin{array}{l}\text { The U.S. review of } 2015 \text { AD rates for Taiwan through } 2015 \text { was } \\
\text { published. } \\
\text { - New rates for Taiwan: } 3.56 \% \text { to } 19.5 \%\end{array}$ & $\begin{array}{l}\text { (U.S. International } \\
\text { Trade Administration } \\
\text { 2017a) }\end{array}$ \\
\hline $\begin{array}{l}\text { July } \\
2017\end{array}$ & $\begin{array}{l}\text { The U.S. review of } 2015 \text { AD rates for China through } 2015 \text { was } \\
\text { published. } \\
\text { - New rates for China: } 9.61 \% \text { to } 165.04 \%\end{array}$ & $\begin{array}{l}\text { (U.S. International } \\
\text { Trade Administration } \\
\text { 2017b) }\end{array}$ \\
\hline $\begin{array}{l}\text { Sept } \\
2017\end{array}$ & $\begin{array}{l}\text { The U.S. review of } 2015 \text { CVD rates for China in } 2015 \text { was } \\
\text { published. } \\
\text { - New rates for China: } 13.93 \% \text { to } 38.43 \%\end{array}$ & $\begin{array}{l}\text { (U.S. International } \\
\text { Trade Administration } \\
\text { 2017c) }\end{array}$ \\
\hline $\begin{array}{r}\text { Nov } \\
2017\end{array}$ & $\begin{array}{l}\text { The U.S. review of } 2015 \text { CVD rates for China in } 2016 \text { was } \\
\text { published. } \\
\text { - New rates for China: } 13.93 \% \text { to } 33.58 \%\end{array}$ & $\begin{array}{l}\text { (U.S. International } \\
\text { Trade Administration } \\
\text { 2017d) }\end{array}$ \\
\hline $\begin{array}{l}\text { June } \\
2018\end{array}$ & $\begin{array}{l}\text { The U.S. review of } 2015 \mathrm{AD} \text { rates for Taiwan in } 2016 \text { was published. } \\
\text { - New rates for Taiwan: } 1.33 \% \text { to } 19.5 \%\end{array}$ & $\begin{array}{l}\text { (U.S. International } \\
\text { Trade Administration } \\
\text { 2018a) }\end{array}$ \\
\hline $\begin{array}{l}\text { April } \\
2019\end{array}$ & $\begin{array}{l}\text { The preliminary U.S. review of } 2015 \text { CVD rates for China in } 2017 \\
\text { was published. } \\
\text { - New rates for China: } 27.65 \% \text { to } 94.83 \%\end{array}$ & $\begin{array}{l}\text { (U.S. International } \\
\text { Trade Administration } \\
\text { 2019f) }\end{array}$ \\
\hline $\begin{array}{l}\text { April } \\
2019\end{array}$ & $\begin{array}{l}\text { The preliminary U.S. review of } 2015 \text { AD rates for Taiwan in } 2017 \\
\text { was published. } \\
\text { - New rates for Taiwan: } 1.00 \% \text { to } 19.5 \%\end{array}$ & $\begin{array}{l}\text { (U.S. International } \\
\text { Trade Administration } \\
\text { 2019c) }\end{array}$ \\
\hline $\begin{array}{l}\text { June } \\
2019\end{array}$ & $\begin{array}{l}\text { A U.S. revision of } 2015 \text { AD rates for Taiwan through 2014-2015 } \\
\text { was published. } \\
\quad \text { - Retroactive rates for Taiwan: } 1.52 \% \text { to } 19.5 \%\end{array}$ & $\begin{array}{l}\text { (U.S. International } \\
\text { Trade Administration } \\
\text { 2019b) }\end{array}$ \\
\hline $\begin{array}{l}\text { June } \\
2019\end{array}$ & $\begin{array}{l}\text { The U.S. review of } 2015 \text { AD rates for China in } 2017 \text { was published. } \\
\text { - New rates for China: } 9.61 \% \text { to } 151.98 \%\end{array}$ & $\begin{array}{l}\text { (U.S. International } \\
\text { Trade Administration } \\
\text { 2019d) }\end{array}$ \\
\hline
\end{tabular}

Finally, a summary of each minimum rate is compared to annual imports of Chinese modules (containing Chinese cells) to the United States in Figure 3.

\footnotetext{
${ }^{4}$ In September 2019, the 2015 AD rates originally administrated for China through 2015 were adjusted such that the range became $3.42 \%$ to $151.98 \%$ (U.S. International Trade Administration 2019e). However, this range is not used in the later analyses in this report, because it only applies up through 2016. The United States did not review the 2015 AD tariffs on China for the years 2016 or 2018, because all petitioners withdrew their requests for a review (U.S. International Trade Administration 2019g, 2017e).
} 


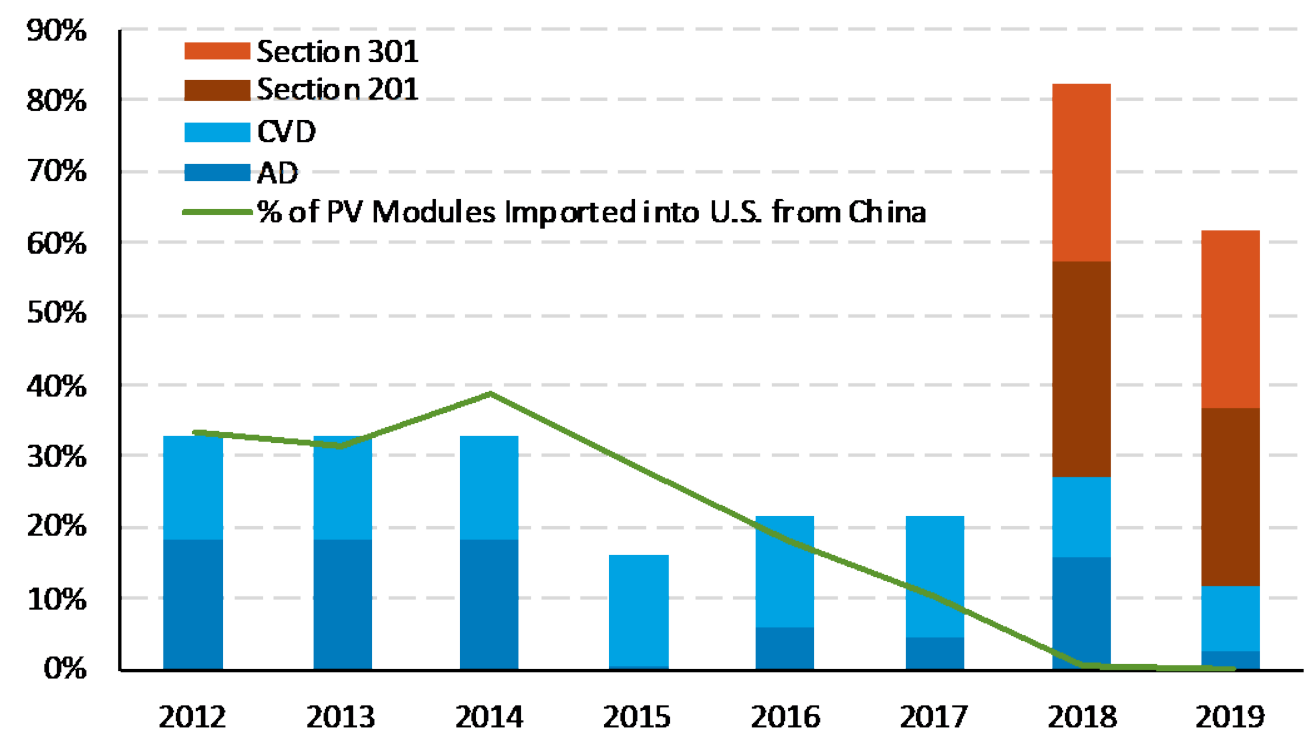

Figure 3. Combined minimum duties on Chinese modules using Chinese cells, compared to China's annual percentage of all PV module imports into the United States

\subsubsection{Extruded Aluminum}

In 2011, AD/CVD tariffs were enacted for extruded aluminum from China. This affects multiple $\mathrm{PV}$ components such as aluminum module frames and PV system racking. The AD rates were $32.79 \%$ to $33.28 \%$ (U.S. International Trade Administration 2011a), while the CVD rates were $8.02 \%$ to $374.15 \%$ (U.S. International Trade Administration 2011b), leading to total rates of $40.81 \%$ to $407.43 \%$. These were reviewed in 2016 and recommended to be continued (U.S. Department of Commerce 2016). Furthermore, new investigations in 2019 are occurring owing to suspected circumvention of the AD/CVD tariffs (U.S. International Trade Administration 2019a).

\subsubsection{Plastic Ribbons, Films, or Sheets}

In 2018, AD/CVD tariffs were enacted for certain plastic ribbon products (including some films or sheets) from China (U.S. International Trade Administration 2018b). This could potentially include certain backsheets or materials used in backsheets, under Harmonized Tariff Schedule (HTS) subheadings 3920 and 3921 . The AD rates range from $54.21 \%$ to $370.04 \%$, while the CVD rates range from $14.27 \%$ to $94.67 \%$. This creates a total range of $68.48 \%$ to $464.71 \%$.

\subsection{Section 201}

The tariffs specifically written for c-Si PV cells and modules are colloquially called "Section 201" tariffs, referring to Section 201 of the Trade Act of 1974 (U.S. Office of the Federal Register 2018b). Section 201 covers industries asking for temporary protection from increased imports, giving them time to become competitive. The Section 201 tariffs introduced in 2018 apply to both cells and modules, but only apply to cells after the first $2.5 \mathrm{GW} /$ year of cell imports into the country each year. These tariffs were enacted in January 2018. The duty rates are as follows:

- If entered during February 7, 2018 through February 6, 2019=30\% 
- If entered during February 7, 2019 through February 6, $2020=25 \%$

- If entered during February 7, 2020 through February 6, $2021=20 \%$

- If entered during February 7, 2021 through February 7, $2022=15 \%$

These tariffs were designed to apply to all countries, although approximately 110 countries deemed to be developing countries were excluded as long as each country's share of imports to the United States does not exceed 3\% and all countries on the list do not cumulatively provide more than $9 \%$ of total U.S. PV cell and module imports. Broadly, the Section 201 tariffs apply to c-Si PV cells and modules (as of July 2018, these correspond to HTS codes 8541.40 .6025 and 8541.40 .6015 , respectively) as well as modules that are either attached to inverters, attached to batteries, or classified as DC generators (HTS codes 8501.61.0010, 8507.20.8000, and 8501.31.8000, respectively) (U.S. Office of the Federal Register 2018b).

However, notable exemptions include any imported modules that contain U.S. cells; if a company wants to use foreign module assembly but they purchase U.S. cells, they can avoid both the Section 201 and Section 301 tariffs (discussed later in Section 2). In spite of this, as of July 2019 , there appeared to be only one c-Si cell manufacturer in the United States producing at a significant scale. Therefore, in effect, this exemption cannot be widely used. Other exemptions include back-contact modules as well as frameless modules of any color other than blue or black, which were excluded beginning in September 2018 (U.S. Office of the Federal Register 2018a). Furthermore, in June 2019, it was announced that all bifacial PV products would be exempted from the Section 201 tariffs (U.S. Office of the Federal Register 2019). ${ }^{5}$

\subsubsection{Cell Import Cap}

As reported in Table 1, in July 2019 approximately $1.3 \mathrm{GW} /$ year of c-Si PV module production capacity existed from 2016. This included the capacity of Auxin Solar, Kyocera, Mission Solar, Prism Solar, Silfab [old Itek facility], Solaria, Solartech Universal, Solartecmx, SunPower, and Unicor. At this time, approximately $0.5 \mathrm{GW} /$ year of announced expansions were already available at full capacity (Auxin Solar, Heliene, Solar Electric America, and SunPower), and an additional planned $3.9 \mathrm{GW} / \mathrm{year}$ were available at partial capacity but expected to reach full capacity by the end of 2019 (Hanwha Q Cells, JinkoSolar, LG, Silfab, and SolarCity/Panasonic). Thus, a total of approximately $5.6 \mathrm{GW} /$ year of c-Si module capacity is expected to be available by the end of 2019 in the United States, once these new facilities have reached full capacity.

As of July 2019, only two U.S. sites had functioning c-Si cell production lines (SunPower in California and SolarCity/Panasonic), with a combined capacity of roughly $0.5 \mathrm{GW} /$ year. ${ }^{6}$ Three companies announced plans to add a total of $0.7 \mathrm{GW} /$ year of new cell capacity (SolSuntech, SunPower, and Sunpreme), but as of July 2019 these plans had either not been realized or were planned to be implemented later in 2019. Furthermore, though the SolarCity/Panasonic plant is expected to increase capacity (possibly adding another $0.6 \mathrm{GW} / \mathrm{year}$ ) to meet job quotas, it has been reported that all cells from this facility are being exported to the Philippines (Tsanova

\footnotetext{
${ }^{5}$ This exemption was reversed in October 2019 and temporarily reinstated by the U.S. Court of International Trade in November 2019. We continue to include the exemption in our cost comparisons in Section 5 in order to illustrate its potential effect on the domestic supply.

${ }^{6}$ The SolarCity/Panasonic capacity is estimated based on the reported 400 Panasonic employees at the site in January 2019 (Whalen 2019), using an estimate of 1 employee per MW of cell capacity based on average cell labor data (Woodhouse et al. 2019).
} 
2019). If cell capacity increases from all companies described in this paragraph and the cells are not exported, c-Si cell production would total $1.8 \mathrm{GW} /$ year. Table 5 summarizes the projected changes in U.S. c-Si cell capacity and necessary cell imports for a best-case scenario, along with the expected outcome based on capacity announcements that have started pilot production as well as accounting for exports.

Table 5. Projected Cell Imports Based on Current U.S. PV Manufacturing Capacity and Company Announcements

\begin{tabular}{|c|c|c|c|}
\hline & Historical & $\begin{array}{c}\text { Projection: } \\
\text { best-case scenario }\end{array}$ & $\begin{array}{c}\text { Projection: } \\
\text { expected outcome }\end{array}$ \\
\hline & $\begin{array}{c}\text { Existing prior to } \\
\text { announcements } \\
\text { (GW/year) }\end{array}$ & $\begin{array}{l}\text { Totals including all } \\
\text { announcements and } \\
\text { existing capacity } \\
\text { (GW/year) }\end{array}$ & $\begin{array}{c}\text { Based on } \\
\text { pilot production } \\
\text { as of July } 2019 \\
\text { (GW/year) }\end{array}$ \\
\hline U.S. c-Si cell capacity & 0.2 & 1.8 & 0.5 \\
\hline $\begin{array}{r}\text { U.S. c-Si cell capacity assumed } \\
\text { to supply cell exports }\end{array}$ & 0 & 0 & 0.4 \\
\hline U.S. c-Si module capacity & 1.3 & 7.5 & 5.6 \\
\hline $\begin{array}{r}\text { Gap between U.S. C-Si cell and } \\
\text { module capacity }\end{array}$ & 1.1 & 5.7 & 5.5 \\
\hline $\begin{array}{r}\text { Cell imports in excess of } 2.5 \\
\text { GW/year Section } 201 \text { cap }\end{array}$ & N/A & 3.2 & 3.0 \\
\hline
\end{tabular}

Thus, the expected outcome is a c-Si cell-module capacity gap of $5.5 \mathrm{GW} /$ year, $3 \mathrm{GW} /$ year of which could be subject to the Section 201 tariffs, if all the module facilities in pilot production as of July 2019 reach full capacity prior to the end of the Section 201 tariff schedule.

Furthermore, the announcements from GreenBrilliance and SolSuntech indicate an additional 0.2 GW/year of module capacity targeted to come online in late 2019, so as of July 2019 there was no evidence of pilot production yet (GreenBrilliance USA 2018; Pickerel 2018d). Plans for another $1.7 \mathrm{GW} /$ year of module capacity were announced by CSUN, Mission Solar, Seraphim Solar USA, Solartech Universal, and Sunpreme, but we have not been able to confirm the status of these additions. If all of these plans were realized, U.S. c-Si PV module production capacity could reach up to $7.5 \mathrm{GW} /$ year. This would correspond to a $5.7 \mathrm{GW} /$ year gap between U.S. cell and module capacity, resulting in $3.2 \mathrm{GW} /$ year of U.S. module capacity relying on imported cells subject to Section 201 tariffs.

\subsubsection{Cumulative Tariffs with AD/CVD}

The Section 201 tariffs apply to PV items that are already subject to the AD/CVD rates described in Section 2.1, creating the effective rates shown in Table 6. 
Table 6. Compound AD/CVD and Section 201 Tariff Rates for c-Si PV Products

\begin{tabular}{|c|c|}
\hline 2019 Section 201 rates of $25 \%$ & Total \\
\hline $\begin{array}{l}\text { Chinese cells after the } 2.5 \text { GW/year } \\
\text { cap, or any module with Chinese } \\
\text { cells }\end{array}$ & $38.31 \%$ to $274.95 \%$ \\
\hline Chinese modules with any cells & $62.26 \%$ to $210.56 \%$ \\
\hline $\begin{array}{l}\text { Taiwanese cells after the } 2.5 \\
\text { GW/year cap, or any module with } \\
\text { Taiwanese cells }\end{array}$ & $26 \%$ to $44.5 \%$ \\
\hline
\end{tabular}

\subsection{Section 232}

In March 2018, tariffs were enacted under Section 232 of the Trade Expansion Act of 1962 (U.S. Customs and Border Protection 2018d). Section 232 authorizes the U.S. Department of Commerce to investigate the effects of imports on national security. In 2018, the presidential administration concluded steel and aluminum imports threatened national security and imposed $25 \%$ tariffs on imported steel and $10 \%$ on imported aluminum. Three countries (Brazil, Argentina, and South Korea) negotiated some exemptions with quotas; Australia negotiated exemptions without a quota.

Because these tariffs were intended to apply to bulk imports of semi-processed metal rather than finished products, they were expected to affect domestic production of racking and mounting structures for PV rather than the more finished products, such as frames and ribbon, necessary for module production. The firms we interviewed indicated that Section 232 tariffs hurt the demand for their products as higher racking costs caused installations to become more expensive. It is unclear to what extent module manufacturing firms are importing aluminum to extrude module frames themselves — subjecting the firms to Section 232 tariffs - rather than importing extruded frames or racking as final products, which are subsequently affected by both AD/CVD and Section 301 tariffs. Prior to the Section 232 tariffs, U.S. racking manufacturers typically imported cheap raw steel and aluminum and extruded it in the United States. However, as a result of the Section 232 tariffs, U.S. racking manufacturers increased imports of fully finished racking products, which are not subject to Section 232 tariffs (Eckhouse and Deaux 2019). This was likely not an intended consequence of the Section 232 tariffs and warrants further analysis; however, cell and module manufacturing are the main focus of this report. In that vein, imported steel used for building greenfield facilities or retrofitting existing buildings for cell and module manufacturing is also often subject to Section 232 or Section 301 tariffs, depending on if the steel was imported as a finished product or not.

\subsection{Section 301}

Tariffs enacted in June $2018^{7}$ applying to a significant amount of Chinese goods are colloquially referred to as "Section 301" tariffs (U.S. Customs and Border Protection 2018e). Section 301

\footnotetext{
${ }^{7}$ The Section 301 tariffs are described in this section regarding their status as of July 2019. These tariffs were modified through June 2018 and July 2019, including rate changes, exclusions, as well as the creation of new lists. Further rate increases and new lists have been announced for implementation towards the end of 2019, but these are not described in or captured by this report and its analysis.
} 
concerns foreign acts, policies, and practices which are determined by the U.S. Trade Representative (USTR) to violate a trade agreement, or to be unjustifiable and burden U.S. commerce.

In 2018, three sets of Section 301 measures were enacted by the United States, each with its own list of Chinese products (U.S. Trade Representative 2018). The first list (List 1) carries a 25\% tariff and was published in June 2018. It includes an entry titled "Parts of diodes, transistors, similar semiconductor devices, photosensitive semiconductor devices, LED's and mounted piezoelectric crystals" (HTS code 8541.90.00). This entry encompasses a large variety of items and includes certain components for PV modules if they are sufficiently specialized to warrant the description "part of a solar panel" (Connor 2019). This has often included extruded anodized aluminum PV module frames (U.S. Customs and Border Protection 2018a). It also includes ethylene vinyl acetate (EVA) encapsulants that are already extruded into film, classified under HTS code 3920.10 (U.S. Customs and Border Protection 2010). Furthermore, this list includes HTS code 8541.40.60, which refers to any diodes other than light-emitting diodes, including solar cells and PV modules. This means any c-Si PV cells or modules are subject to AD/CVD, Section 201, and Section 301 tariffs, while any other PV technologies (such as thin-film modules) are subject to Section 301 tariffs. The cumulative tariffs for c-Si PV products coming from China are reported in Table 7.

Table 7. Compounded Tariff Rates for c-Si PV from China from Section 301 List 1, Section 201, and AD/CVD Tariffs

\begin{tabular}{|c|c|}
\hline Assumes Section 201 rates of $25 \%$ & Total \\
\hline $\begin{array}{l}\text { Chinese cells imported after the } 2.5 \text { GW/year cap has been reached, } \\
\text { or any module with Chinese cells }\end{array}$ & $63.31 \%$ to $299.95 \%$ \\
\hline Chinese modules with any cells & $87.26 \%$ to $235.56 \%$ \\
\hline
\end{tabular}

The second list (List 2) targeted a 25\% tariff in August 2018 and included iron, steel, and aluminum, which are used in wiring and racking for PV systems. The subheadings that are most likely to include backsheets or sheets of material for backsheets (HTS codes 3919, 3920, and 3921) are included extensively on both Lists 1 and 2. Thus, for the purposes of this analysis, it is assumed that backsheets or backsheet materials from China carry a Section 301 tariff of 25\%.

The third list (List 3) includes HTS categories that encompass junction boxes and inverters (HTS codes 8544.42.9090 and 8504.40.9570, respectively). It also includes silicone-based sealants classified under HTS code 3214.10 (U.S. Customs and Border Protection 2009). This third list was initially published on September 21,2018 , for a $10 \%$ duty, but increased to $25 \%$ on May 9 , 2019 (U.S. Trade Representative 2019). This list includes most flat glass including tempered glass, which is needed for PV module production (often referred to as cover glass in customs rulings).

Table 8 shows a list of PV components and bill of materials (BoM) materials included in the Section 301 tariffs. The HTS codes in this list were reviewed with the U.S. Department of Homeland Security and are assumed to be accurate to the extent of our knowledge (Connor 
2019). This list does not include any machinery used to manufacture PV modules; however, it is possible that such items are included in the Section 301 lists as well.

Table 8. PV Module and BoM Items Included in Section 301 Tariffs and Their Respective HTS Codes and Duty Rates if Sourced from China

\begin{tabular}{|c|c|c|c|}
\hline Component & $\begin{array}{c}\text { HTS Code } \\
\text { (varies by how item } \\
\text { is classified) }\end{array}$ & Description & Tariffs \\
\hline \multirow[t]{2}{*}{ Aluminum frame } & $\begin{array}{l}\text { 7616, possibly } \\
7616.99 .51\end{array}$ & $\begin{array}{l}\text { Other articles of } \\
\text { aluminum including } \\
\text { frames }\end{array}$ & $\begin{array}{l}\text { - Section } 301 \mathrm{List} \\
3=10 \% \text { to } 25 \% \\
\text { - Existing } 2.5 \% \\
\text { general duty } \\
\text { AD/CVD rates of } \\
40.81 \% \text { to } \\
407.43 \% \\
\text { Total }=\mathbf{5 3 . 3 \%} \text { to } \\
\mathbf{4 3 4 . 9 3 \%}\end{array}$ \\
\hline & 8541.90 & $\begin{array}{c}\text { Parts of semiconductor } \\
\text { devices }\end{array}$ & $\begin{array}{l}\text { - Section } 301 \text { List } \\
1=25 \% \\
\text { - AD/CVD rates of } \\
40.81 \% \text { to } \\
407.43 \% \\
\text { Total }=65.81 \% \text { to } \\
\mathbf{4 3 2 . 4 3 \%}\end{array}$ \\
\hline \multirow[t]{2}{*}{ Junction boxes } & 8544.42 .9090 & $\begin{array}{l}\text { Insulated electric } \\
\text { conductors fitted with } \\
\text { connectors }\end{array}$ & $\begin{array}{l}\text { - Section } 301 \text { List } \\
3=10 \% \text { to } 25 \% \\
\text { - Existing } 2.6 \% \\
\text { general duty } \\
\text { Total }=\mathbf{1 2 . 6 \%} \text { to } \\
\mathbf{2 7 . 6 \%}\end{array}$ \\
\hline & 8541.90 & $\begin{array}{c}\text { Parts of semiconductor } \\
\text { devices }\end{array}$ & $\begin{array}{c}\text { Section } 301 \text { List } 1= \\
25 \%\end{array}$ \\
\hline \multirow{3}{*}{$\begin{array}{l}\text { Tabbing, busbar, or } \\
\text { string connector } \\
\text { ribbons }\end{array}$} & 7409 & $\begin{array}{l}\text { Copper plates, sheets, } \\
\text { and strip, of a thickness } \\
\text { exceeding } 0.15 \mathrm{~mm}\end{array}$ & $\begin{array}{l}\text { - Section } 301 \text { List } \\
3=10 \% \text { to } 25 \% \\
\text { - Existing } 3 \% \\
\text { general duty } \\
\text { Total }=\mathbf{1 3} \% \text { to } \\
\mathbf{2 8 \%}\end{array}$ \\
\hline & $\begin{array}{c}\text { 8536, likely } \\
8536.69 .40 \text { or } \\
8536.90 .85\end{array}$ & $\begin{array}{l}\text { Electrical apparatus for } \\
\text { making connections in or } \\
\text { to electrical circuits }\end{array}$ & $\begin{array}{c}\text { If } 8536.69 .40 \text { or } \\
8536.90 .85, \text { Section } \\
301 \text { List } 1=25 \% \\
\\
\text { If } 8536.90 .85 \text {, add } \\
\text { existing } 0.6 \% \\
\text { general duty = } \\
25.6 \%\end{array}$ \\
\hline & 8541.90 & $\begin{array}{c}\text { Parts of semiconductor } \\
\text { devices }\end{array}$ & $\begin{array}{c}\text { Section } 301 \text { List } 1= \\
25 \%\end{array}$ \\
\hline $\begin{array}{l}\text { Tempered low-iron } \\
\text { glass with } \\
\text { antireflective } \\
\text { coatings (ARC), or } \\
\text { "cover glass" }\end{array}$ & 7007.19 & $\begin{array}{l}\text { Safety glass, consisting } \\
\text { of toughened (tempered) } \\
\text { or laminated glass for } \\
\text { applications other than } \\
\text { aircraft, ships, or } \\
\text { automobiles }\end{array}$ & $\begin{array}{l}\text { - Section } 301 \text { List } \\
3=10 \% \text { to } 25 \% \\
\text { - Existing } 5 \% \\
\text { general duty } \\
\text { Total }=\mathbf{1 5 \%} \text { to } \\
\mathbf{3 0 \%}\end{array}$ \\
\hline
\end{tabular}




\begin{tabular}{|c|c|c|c|}
\hline Component & $\begin{array}{c}\text { HTS Code } \\
\text { (varies by how item } \\
\text { is classified) }\end{array}$ & Description & Tariffs \\
\hline EVA encapsulant & 3920.10 & $\begin{array}{l}\text { Plates, sheets, film, foil, } \\
\text { etc. of ethylene polymers } \\
\text { (noncellular and not } \\
\text { combined with other } \\
\text { materials) }\end{array}$ & $\begin{array}{l}\text { - Section } 301 \text { List } \\
2=25 \% \\
\text { - Existing } 4.2 \% \\
\text { general duty } \\
\text { Total }=\mathbf{2 9 . 2} \%\end{array}$ \\
\hline Silicone edge sealant & 3214.10 & $\begin{array}{l}\text { Caulking compounds } \\
\text { and other mastics }\end{array}$ & $\begin{array}{c}\text { - Section } 301 \text { List } \\
3=10 \% \text { to } 25 \% \\
\text { - Existing } 3.7 \% \\
\text { general duty } \\
\text { Total }=\mathbf{1 3 . 7 \%} \text { to } \\
\mathbf{2 8 . 7 \%}\end{array}$ \\
\hline Backsheets & $\begin{array}{l}3919 \\
3920 \\
3921\end{array}$ & $\begin{array}{l}\text { 3919: self-adhesive } \\
\text { 3920: single-material } \\
\text { 3921: laminates/ } \\
\text { combination of films }\end{array}$ & $\begin{array}{l}\text { - Section } 301 \text { List } \\
2=25 \% \\
\text { - Existing general } \\
\text { duty }=3 \% \text { to } 7 \% \\
\text { - AD/CVD rates of } \\
68.48 \% \text { to } \\
464.71 \% \\
\text { Total }=96.48 \% \text { to } \\
\mathbf{4 9 6 . 7 1 \%}\end{array}$ \\
\hline Inverters & 8504.40 .9570 & Inverters & $\begin{array}{l}\text { - Section } 301 \text { List } \\
3=10 \% \text { to } 25 \%\end{array}$ \\
\hline
\end{tabular}

\subsection{U.S. Corporate Tax Rate}

In December 2017, the $115^{\text {th }}$ U.S. Congress passed a bill that reduced the corporate tax rate from $35 \%$ to $21 \%$ (United States Congress 2017). The new rates took effect beginning January 1 , 2018. While a change in tax rate is not a trade policy per se, it may impact firm decision making with respect to expanding manufacturing in the United States versus importing products from overseas. Thus, it is included here.

\section{U.S. PV Manufacturing Announcements, 2017-2019}

We conducted a review of U.S. PV manufacturing capacity announcements from January 2017 to July 2019. The beginning of this interval was selected to encompass a jump in capacityexpansion announcements occurring through 2017 and onwards. This allows announcements to be included that anticipated the USITC ruling on domestic competitiveness with PV imports in September 2017 (which was initiated in May 2017), and it enables analysis of announcements for which capacity totals were revised after the USITC ruling (U.S. International Trade Commission 2017). Figure 4 maps these announced expansions, and further detail can be found in the appendix and in a previous report (Smith and Margolis 2019). Announced expansions can be grouped into three categories: 1) expansions by existing manufacturers, 2) expansions via acquisition of existing U.S. PV facilities from another firm, and 3) expansions by new firms entering the U.S. market. 


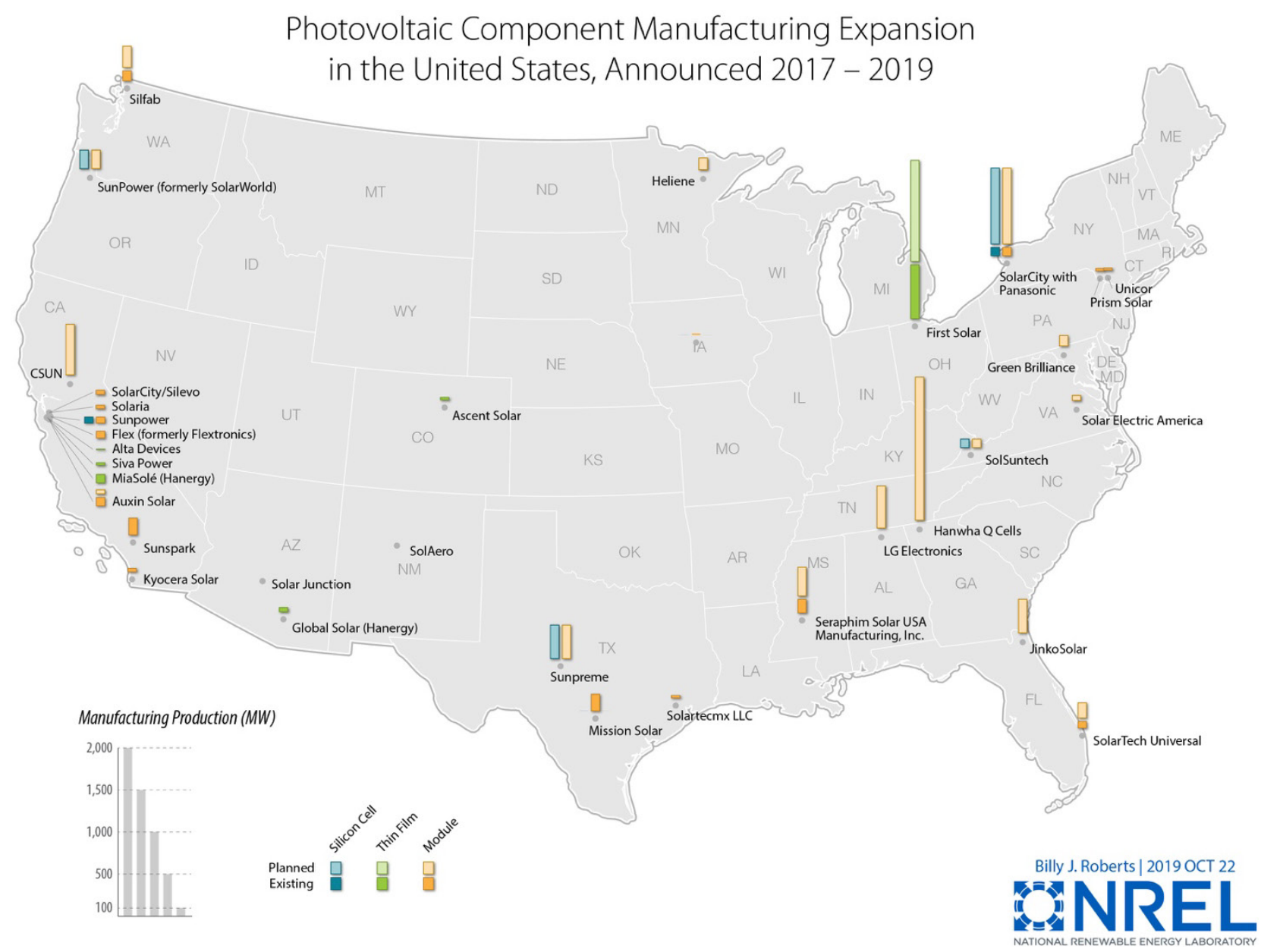

Figure 4. Existing U.S. PV manufacturing capacity in 2016, and expansions announced January 2017 to July 2019

Expansions announced by existing U.S. manufacturers. Six existing U.S. PV module manufacturers announced plans for capacity expansions between January 2017 and July 2019:

- Mission Solar announced in February 2018 that it would be adding $0.2 \mathrm{GW} /$ year at its existing site in Texas, for a total of $0.4 \mathrm{GW} /$ year of monocrystalline passivated emitter and rear cell (mono-PERC) module capacity (Roselund 2018b). However, no additional capacity was confirmed as of July 2019.

- Seraphim Solar (a U.S. subsidiary of a Chinese parent company) announced in March 2017 that it would add $0.2 \mathrm{GW} /$ year of module capacity at its existing site in Mississippi (Osborne 2017b). In October 2018, it announced that it would add 0.36 $\mathrm{GW} /$ year rather than $0.2 \mathrm{GW} /$ year, which would bring its total U.S. production capacity to $0.5 \mathrm{GW} /$ year of half-cut cell mono-PERC modules (Weatherly 2018). However, no additional capacity was confirmed as of July 2019.

- SolarCity announced plans in 2014 for a $1 \mathrm{GW} /$ year module production facility in New York, and Panasonic joined the venture in 2016 (Robinson and Precious 2017). We estimate that, as of August 2017, roughly $0.1 \mathrm{GW} /$ year of module assembly were 
already operational, ${ }^{8}$ and a capacity of $1 \mathrm{GW} /$ year was targeted for 2019. Intentions to increase the capacity eventually to $2 \mathrm{GW} /$ year were also announced in August 2017 but without a specific timeframe (Lambert 2017). This report only considers the first GW/year of capacity expected to come online in 2019. However, specific quantities of capacity were not confirmed as of July 2019.

- First Solar announced plans in April 2018 for a new 1.2 GW/year CdTe PV manufacturing facility in Ohio. This would be its second location in Ohio, bringing its total CdTe module production capacity in the state to $1.8 \mathrm{GW} /$ year (Pickerel 2018a). Production of modules is underway as of April 2019, and full capacity is expected soon.

- SolarTech Universal announced plans in December 2017 to build $0.18 \mathrm{GW} /$ year of module production capacity in Puerto Rico, but it switched the planned location to Florida after Hurricane Maria. This would bring the company's total module production capacity in Florida to $0.26 \mathrm{GW} /$ year (Weaver 2018b). However, no additional capacity was confirmed as of July 2019.

- Auxin Solar reported in September 2018 that it was operating at $0.15 \mathrm{GW} /$ year of module production capacity as an original equipment manufacturer (OEM) at its existing California location. Its 2018 production level was an increase of 0.05 GW/year above its 2017 production level (Pickerel 2018b). Auxin has been operating at the full $0.15 \mathrm{GW} / \mathrm{year}$ since September 2018 or earlier.

Expansions via acquisition of existing U.S. PV facilities. Three existing PV manufacturing facilities were acquired by new companies and brought online under new management, including:

- SunPower (U.S. company) announced plans to acquire SolarWorld's cell and module production facilities in Oregon in April 2018, and acquisition was completed in October 2018. As of February 2019, the facility was operating at a module capacity of $0.22 \mathrm{GW} /$ year of shingled mono-PERC module production. No cell capacity has been confirmed at the Oregon site since its acquisition by SunPower.

- Heliene (Canadian company) announced in September 2017 that it planned to acquire and operate Silicon Energy's facility in Minnesota, with a capacity $0.14 \mathrm{GW} /$ year of mono-PERC modules (Jossi 2018). Heliene was one of the first capacity-expansion announcements to start producing modules, beginning in the summer of 2018 (Foehringer Merchant 2018a).

- Silfab (Canadian company) announced plans to purchase Itek Energy's facility in Washington State in August 2018. Its initial plan was to add roughly $0.2 \mathrm{GW} /$ year of capacity to the existing $0.12 \mathrm{GW} /$ year at this facility, for a total of $0.35 \mathrm{GW} / \mathrm{year}$ of mono-PERC module capacity. However, in March 2019, it updated its expansion plans to add $0.25 \mathrm{GW} /$ year for a total of roughly $0.4 \mathrm{GW} /$ year of module capacity (Roselund 2019). As of April 2019, the Silfab facility was producing at $0.2 \mathrm{GW} /$ year of capacity, and full capacity is expected soon.

Expansions by new firms entering the U.S. market. Eight new firms announced plans to build new U.S. module manufacturing facilities:

\footnotetext{
${ }^{8}$ The SolarCity/Panasonic capacity is estimated based on the reported approximately 50 employees at the site in June 2017 (Robinson and Precious 2017), using an estimate of 0.6 employees per MW of module capacity based on average module assembly labor data (Woodhouse et al. 2019).
} 
- CSUN (Chinese company) announced plans in February 2017 to build a $0.4 \mathrm{GW} /$ year module facility in a vacant building in McClellan Park, California (Pickerel 2017a). In June 2018, CSUN increased the planned capacity of this facility to $0.6 \mathrm{GW} /$ year (Pickerel 2018e). However, no capacity was confirmed as of July 2019.

- Hanwha Q Cells (South Korean company) announced in May 2018 that it would build a $1.7 \mathrm{GW} /$ year greenfield facility in Georgia to produce PERC modules using half-cut cells (Parnell 2018). As of April 2019, the facility was reported to be approaching $1 \mathrm{GW} /$ year of capacity and is expected to reach full capacity by the end of the year. ${ }^{9}$

- JinkoSolar (Chinese company) announced in March 2018 that it would build a 0.4 GW/year mono-PERC module production facility in a vacant building in Florida (Brune Mathis 2018b). As of May 2019, the facility was fully equipped and staffed.

- LG Electronics (Korean company) announced in June 2018 that it would build 0.5 $\mathrm{GW} /$ year of module capacity on the existing LG campus in Alabama, using a vacant building that had previously been used for TV and microwave production (Pyper 2018). Production of modules was underway as of April 2019, and full capacity is expected soon.

- GreenBrilliance (U.S. company) announced in July 2018 that it would build a 0.125 GW/year bifacial module facility in Maryland (GreenBrilliance USA 2018). GreenBrilliance previously operated solely as an installer in the United States, although its subsidiary had module production in India. This announcement set a target date for late 2019, so capacity has not yet been confirmed.

- Solar Electric America (U.S. company) opened a 0.06 GW/year OEM module facility in Richmond, Virginia, at a former die plant sometime in 2017 (Pickerel 2018b). Solar Electric America previously operated exclusively as a U.S. solar installer. This facility has been equipped to produce at its full $0.06 \mathrm{GW} /$ year capacity since 2017.

- SolSuntech (U.S. Company) announced in October 2018 plans to build a 0.1 $\mathrm{GW} /$ year corrugated wafer, cell, and module production line in a former furniture assembly facility in St. Paul, Virginia (Pickerel 2018d; Industrial Development Authority of Russell County Virginia 2019). This announcement set a target date for late 2019, so capacity has not yet been confirmed.

- Sunpreme (U.S. company) announced in July 2017 that it was planning a 0.3 GW/year facility in Nevada, but in September 2018 announced it would build a 0.4 GW/year bifacial cell and module production facility in Texas (Foehringer Merchant 2018b). However, no capacity was confirmed as of July 2019.

Out of 17 announced U.S. expansions between January 2017 and July 2019, only four (SolarCity with Panasonic, Solsuntech, SunPower, and Sunpreme) included cell production in addition to module production. First Solar's announced addition of $1.2 \mathrm{GW} /$ year of thin-film module production capacity can also be considered equivalent to cell and module production (although a distinction between cell and module production is not appropriate for the fully integrated thinfilm module process, in which semiconductor raw materials are directly converted to finished modules within the same factory). During this period, two other companies (Solaria and LONGi) initially expressed an interest in or intent to add/expand U.S. manufacturing but later cancelled

\footnotetext{
${ }^{9}$ The Hanwha Q Cells location in Georgia had its grand opening in September 2019 at a finished capacity of 1.7 GW/year.
} 
their plans. Solaria announced plans in January 2018 to add 200 MW of U.S. capacity separately from its existing $40 \mathrm{MW}$ California facility but later abandoned this plan. LONGi indicated it was considering adding a U.S. facility, but no further action was taken as of July 2019.

\subsection{Timeline}

A timeline of when PV expansion announcements occurred between January 2017 and July 2019 is displayed in Figure 5, along with an overlay of relevant policy actions. Six announcements occurred before the USITC ruling in September 2017 (U.S. International Trade Commission 2017): CSUN, Seraphim Solar USA, Solar Electric America, Sunpreme, SolarCity with Panasonic, and Heliene. Three of the firms increased production targets after the cell and module tariffs took effect in January 2018 (CSUN, Seraphim, and Sunpreme); however, two of these firms (Seraphim and Sunpreme) waited until after tariff exclusions were announced in September 2018 to increase their targets (U.S. Customs and Border Protection 2018c; U.S. Office of the Federal Register 2018a). SolarTech Universal made an announcement after the 2018 tax bill was passed but before it was enacted, while Solaria and Mission Solar made announcements after the new corporate tax rate took effect but before the tariffs took effect.

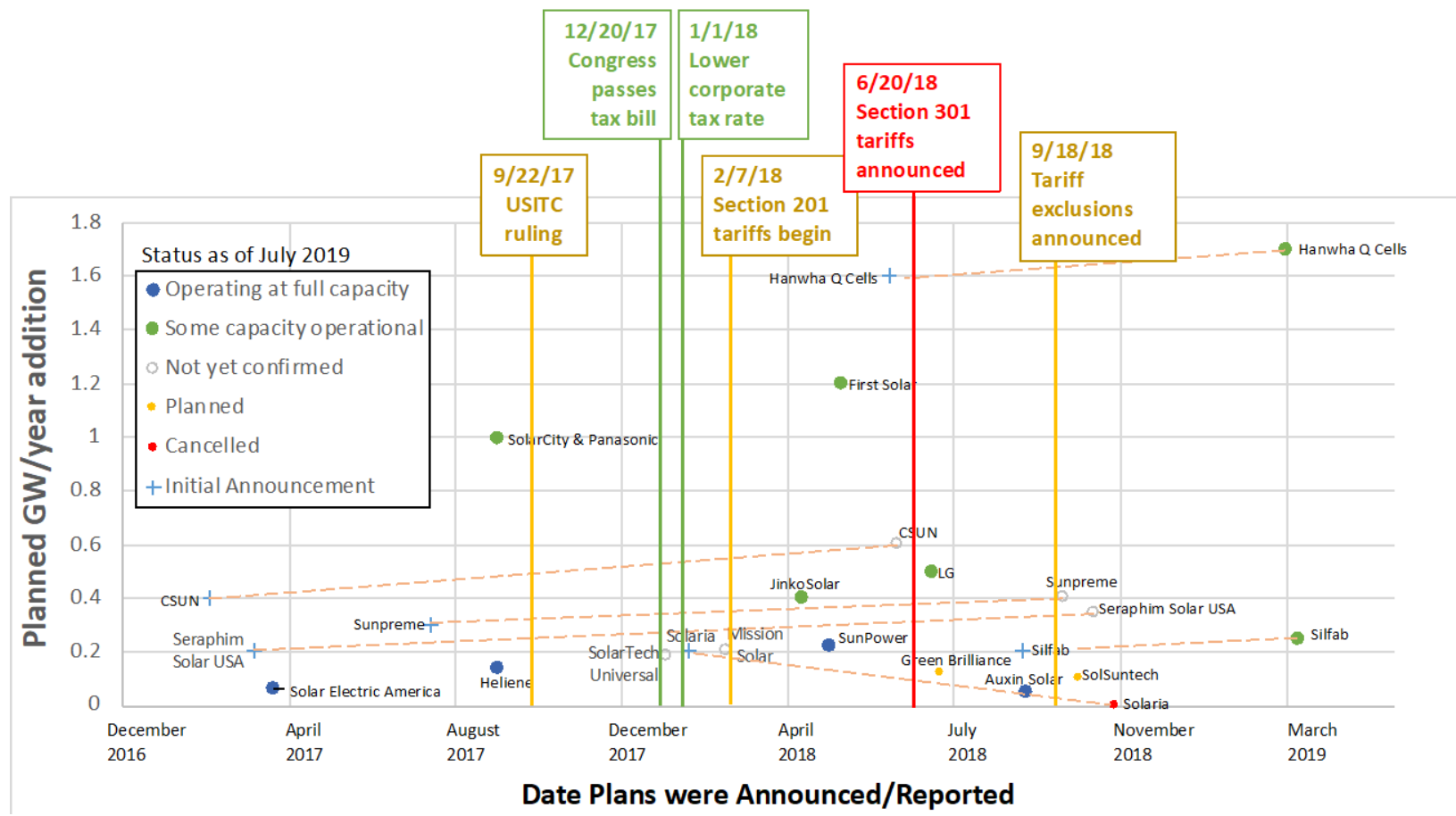

Figure 5. Timeline of U.S. PV manufacturing capacity-expansion announcements

Seven other companies made announcements after the tariffs took effect, including JinkoSolar, SunPower, First Solar, Hanwha Q Cells, LG Electronics, GreenBrilliance, and Silfab. This group contains the largest capacity announcements in the series reported here. Finally, SolSuntech announced its plans to locate in the United States after the tariff exclusions were published. SolSuntech's plans include wafer sawing and cell production in addition to module assembly, so the company might have been waiting on the exclusion decisions to make its announcement. Auxin Solar increased its capacity at some point prior to the exclusions being announced, but it 
is not known exactly when. Both Silfab and Hanwha Q Cells increased their targets some months after the exclusions were announced as well.

\subsection{Announcement Features}

A more detailed picture of select aspects of the announcements is shown in Figure 6 . The announcements are categorized by GW/year of module capacity additions. The appendix reports the detailed data and attributes the data to the 17 specific companies.

Figure 6a displays the percentage of announcements that are expansions of companies with preexisting U.S. facilities versus those establishing their first U.S. location. The vast majority of planned capacity additions are either associated with companies that have no existing U.S. presence (no physical U.S. manufacturing, research and development [R\&D], or installer facilities) $(45 \%)$ or those that already have existing U.S. PV manufacturing (41\%). The remaining $14 \%$ is associated with companies that manufacture non-PV items such as LG Electronics (7\%), have a U.S. solar R\&D facility and make significant use of U.S. OEMs (5\%), or were previously only present in the United States as a solar installation company (1\%) but maintained module production in India (2\%).

Figure $6 \mathrm{~b}$ shows the percentage of announcements by company nationality, defined as where the company is headquartered. The largest share of additions is associated with domestic companies or subsidiaries (50\%); this includes the SolarCity/Panasonic partnership as a domestic venture. These are followed by South Korean companies (29\%), Chinese companies (14\%), and Canadian companies or subsidiaries $(7 \%)$.

Because most announcements are for module production only or include an equivalent amount of cell and module production, Figure $6 \mathrm{c}$ reports where the cells that would be used to construct these modules are manufactured. The largest share (38\%) would be from existing U.S. facilities $(12 \%$, SolarCity) or new cell capacity planned to be built in concert with new module capacity (10\%, including SolSuntech, SunPower, and Sunpreme; 16\%, First Solar). The second-largest share (32\%) would be from South Korea, including Hanwha Q Cells, LG, Silfab and Mission Solar. At least $8 \%$ would be from Southeast Asia, including 5\% from Malaysia (JinkoSolar) and $3 \%$ from Taiwan (Auxin and Silfab). A significant amount (22\%) of cell source countries is unknown.

Figure 6d reports the prevalence of different cell architectures being used as inputs in the new module capacity announcements. Owing to the proprietary nature of some cell technologies and/or lack of information, 38\% of cell architectures are unknown. However, $41 \%$ use monoPERC architecture, while $16 \%$ of cells are CdTe, and the 5\% from Sunpreme have a silicon hetero-junction (SHJ)-like architecture.

Figure 6e reports the facility type used (or planned to be used) to house the manufacturing equipment. The largest share of capacity (39\%) would be housed in a greenfield facility, which is attributed only to the two largest facilities in this set: Hanwha Q Cells and First Solar. Existing facilities previously used for a non-PV purpose account for 34\%, expansions of an existing PV manufacturer's facility account for $13 \%$, and retooled older PV facilities purchased by a new company account for $5 \%$. A small fraction (9\%) of facility types is unknown. 
a) Existing U.S. Presence

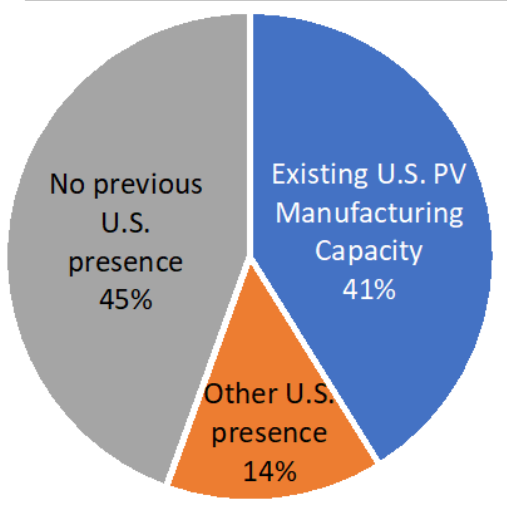

c) Cell Sourcing

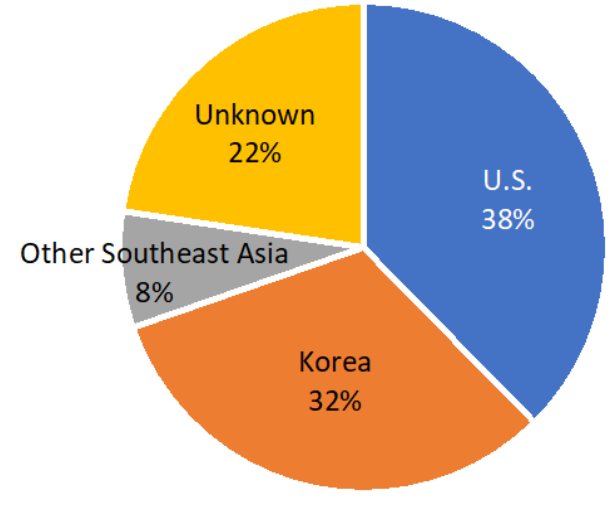

e) Facility Type

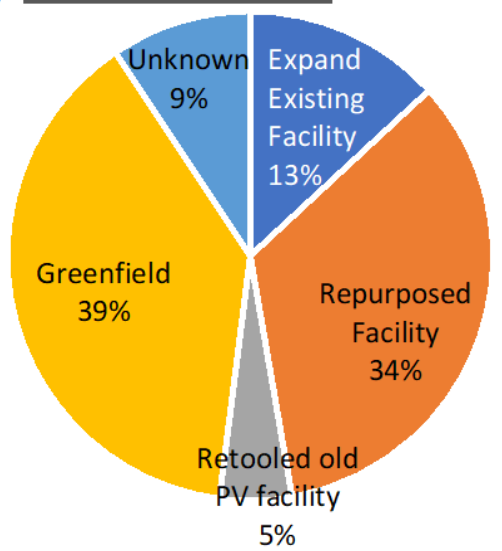

b) Company Nationality

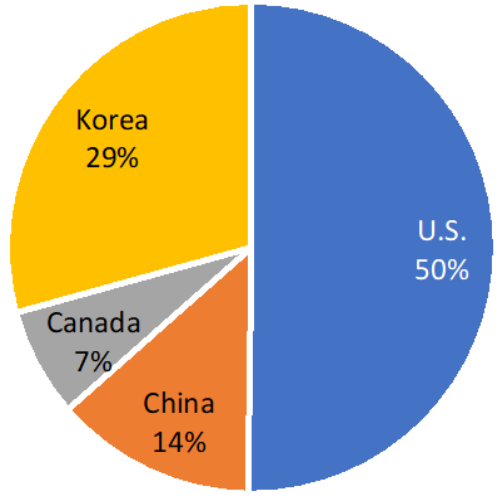

d) Cell Architecture

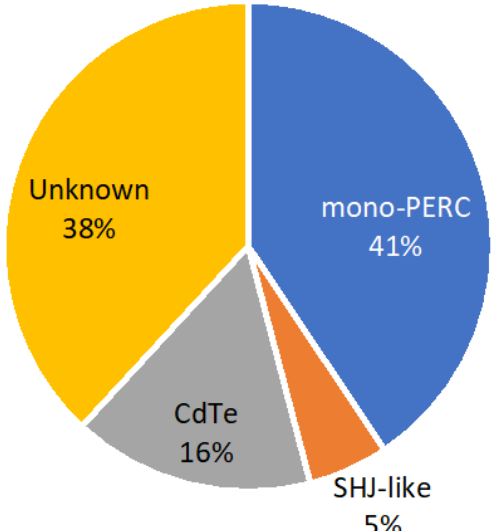

f) $\underline{\text { Target Markets }}$

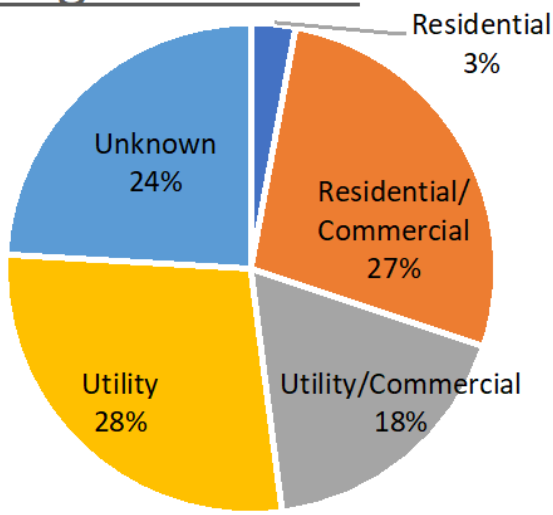

Figure 6. Announcement analysis quantified by GW/year of added capacity for a) existing U.S. presence, b) company nationality, c) cell sourcing, d) cell architecture, e) facility type, and f) target market 
Finally, Figure $6 \mathrm{f}$ reports the target markets of the announcements. The largest fraction of capacity (28\%), from Hanwha Q Cells and JinkoSolar, prioritizes utility markets, though commercial and residential products are also present to a lesser degree. The second-largest category (27\%) targets both residential and commercial installations (GreenBrilliance, LG, Seraphim, Silfab, SolarTech Universal, SolSuntech, and Sunpreme), while a much smaller fraction (3\%, SunPower) targets the residential sector exclusively. The combined utility and commercial sectors account for 18\% (Heliene and First Solar). The target sectors for 24\% of capacity are unknown.

We calculate a capacity-specific employment metric for the announcements that have employment estimates (Figure 7a). Labor intensity for the group varies between roughly 300 to 1,500 employees per GW/year of module manufacturing capacity. Based on this group, labor intensity apparently decreases with increasing scale of the plant. It is unclear to what extent this could be a benefit of scale or the result of automation serving as a confounding variable that both decreases labor and is more easily achieved by firms operating at larger scale. The quantities reported in this figure can also be compared to the standard labor intensities assumed for the National Renewable Energy Laboratory's (NREL's) detailed bottom-up c-Si cost model, specifically 500-700 jobs per GW/year for more automated sites and 1,000-2,000 jobs per $\mathrm{GW} /$ year for more labor-driven sites (Woodhouse et al. 2019).

a)

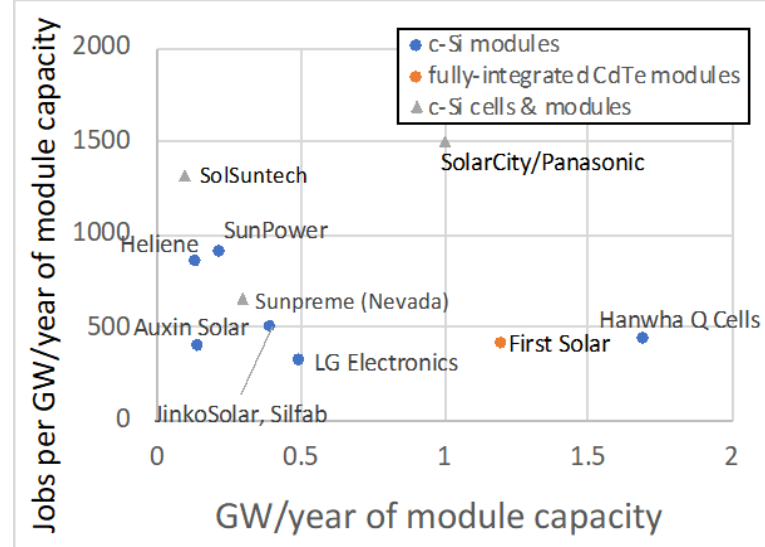

b)

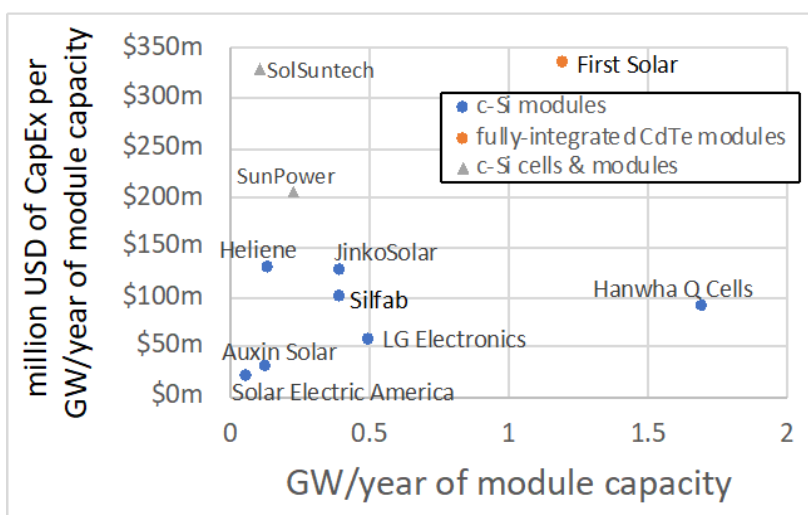

Figure 7. a) Employees per GW/year of module capacity as a function of plant size, and b) CapEx per GW/year of module capacity as a function of plant size

We calculate a capacity-specific CapEx metric for the announcements that report this information (Figure 7b), which varies between 20-130 million U.S. dollars (USD) per GW/year of c-Si module capacity. Based on this group, CapEx per GW/year appears to be approximately flat as plant scale increases. First Solar's factory CapEx reflects that of a fully integrated thinfilm module factory, in which semiconductor raw materials are fully converted to a PV module. The SolSuntech and SunPower investments are quoted for onsite c-Si cell production, and SolSuntech includes wafer cutting as well, yielding a range of 200-330 million USD per GW/year of both c-Si cell and module capacity. The SolarCity/Panasonic facility is excluded from this figure; reports estimated a total facility investment approaching \$1 billion (Robinson and Precious 2017), corresponding to a CapEx intensity of 950 million USD per GW/year. This is more than twice as high as any other company shown in Figure $7 \mathrm{~b}$, where the highest values 
represented by First Solar and SolSuntech include the equivalent of wafer, cell, and module production.

Figure 8a shows the relationship between facility capacity and amount of local incentives for announcements with the required information. Based on this dataset, incentives vary between 155 million USD per GW/year of module capacity. However, the number of facilities with the required information is small, and the information may be incomplete for the companies shown here. In addition, SolSuntech's facility is planning to perform wafer-cutting, cell production, and module manufacturing and therefore appears to have a disproportionate amount of incentives compared to its module capacity. Again, the SolarCity/Panasonic facility is excluded from this figure, because the data are from 5 years ago; this facility's incentives are much higher than all the others, at 750 million USD per GW/year of module capacity. The specific quantities and references for these data are shown in Table 16 in the appendix.

Figure $8 \mathrm{~b}$ shows the ratio of incentives to CapEx for announcements with the required information, ranging from 0.06-0.20 USD of incentives per dollar of CapEx. The dataset here is even more limited than in Figure 8a, but this metric is more robust in accounting for multiple production steps occurring at the same facility. The SolarCity/Panasonic facility, which is not plotted, has a ratio of 0.80 .

Finally, Figure 9 shows the value of incentives received per job at each facility where data are available. It ranges from 8,000-40,000 USD per employee and appears to have a positive relationship with plant size. The value for the excluded SolarCity/Panasonic facility is 750,000 USD per employee.

a)

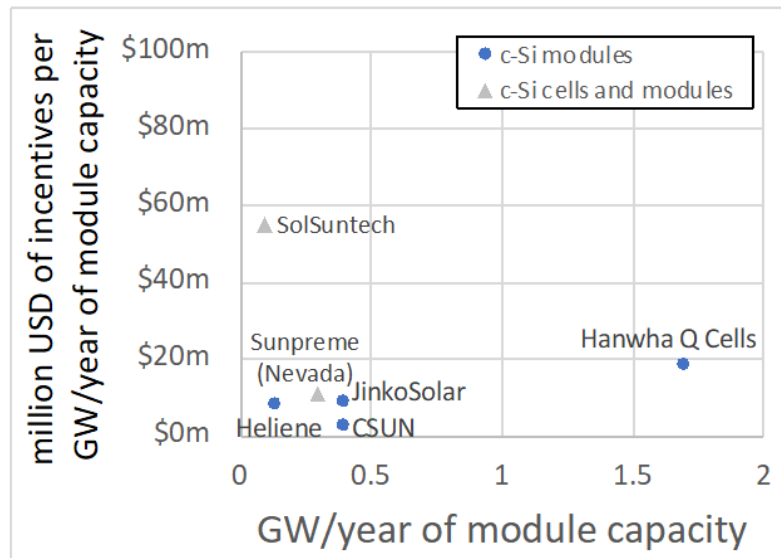

b)

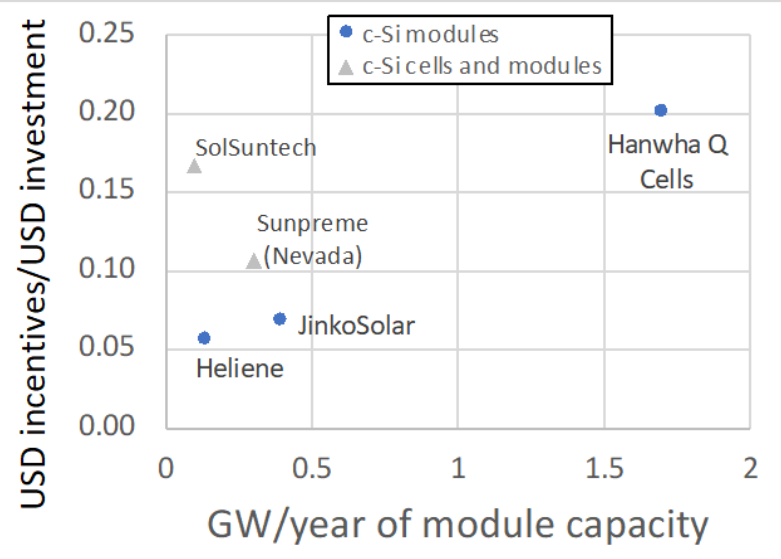

Figure 8. a) Local financial incentives per GW/year of module capacity as a function of plant size, and b) local financial incentives per USD CapEx as a function of plant size 


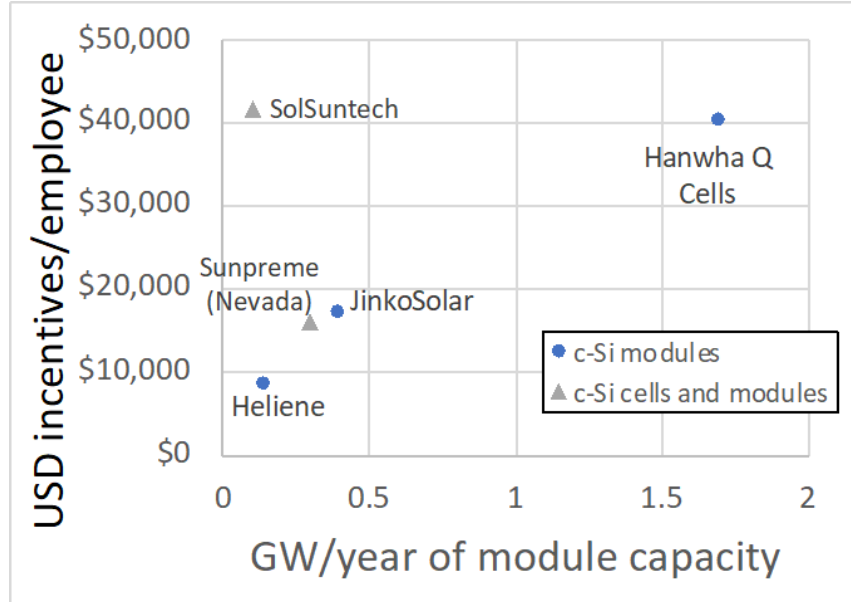

Figure 9. Local financial incentives per employee as a function of plant size

\section{Case Studies}

In the first half of 2019, we interviewed representatives at eight of the firms that announced plans for expanded U.S. production since early 2017. The firms include Auxin Solar, which had an $8 \%$ share of U.S. module production capacity in 2017, First Solar (48\%), Hanwha Q Cells $(0 \%)$, JinkoSolar (0\%), LG (0\%), Silfab (9\%), Solaria (3\%), and SunPower (5\%). The proposed expansions of these eight firms represent $4.4 \mathrm{GW}$, which is $70 \%$ of all proposed expansions. The firms were selected to cover a range of sizes, locations, ownership structures, and technologies. The interview questions posed to these firms were divided into four categories:

\section{The role of local market demand}

- Did proximity to demand (local or national) play a role in your decision making?

- Did you have contracts to supply panels locally (or anywhere in the United States) prior to your decision?

\section{The role of incentives}

- Did the tariffs play any role in your decision making?

- Did the reduction in the U.S. national corporate tax rate that took effect in 2018 play a role in your decision making?

- Were there any other federal incentives that affected your decision making?

- Were there any local policies or incentives (including tax incentives, access to existing facilities/equipment, etc.) that influenced your decision making?

\section{The role of local labor costs/labor markets}

- Were local labor rates/rules a consideration in your decision making with respect to choosing a specific locality?

- What role did proximity to trained labor play, if any?

- What role did the degree of automation in manufacturing play in your decision making?

\section{The role of other factors}

- Was obtaining financing an issue/challenge?

- What factors may have the biggest impact on your decision making going forward? 
- What other factors influence your decision making?

We summarized these interviews and a survey of literature (mostly press announcements and trade publications) in order to create the case studies described in this section. The case studies highlight the importance of the following five factors in influencing firms' decisions to expand their U.S. PV production capacity:

- Proximity to demand. For most firms, a major motivation to locate manufacturing in the United States was the significant domestic U.S. demand for their technology through existing supply chains or specific supply contracts. Multiple firms also noted that demand for made- or assembled-in-USA products, including supply contracts with minimum domestic content requirements, was an important driver.

- Ability to move quickly. Most firms mentioned the desire to move quickly to maximize the benefits of the Section 201 tariffs. This included moving into vacant buildings, relocating existing equipment from other PV manufacturing sites, or purchasing existing solar facilities while upgrading equipment and retaining the employees. Similarly, some firms mentioned the ease and rapidity of facility acquisition and permitting as a deciding factor for selecting a locality. Some firms cited the time and investment necessary for cell-fabrication facilities as a major reason for the lack of much existing or planned U.S. cell capacity.

- Tariffs and other incentives. Most firms seemed supportive of the Section 201 tariffs, although they commonly expressed the belief that the cell import cap should be higher than $2.5 \mathrm{GW} /$ year. Most firms also said they located new capacity in existing facilities or buildings to reduce lead time and capitalize on the Section 201 tariffs as soon as possible. However, most firms stated that the Section $301^{10}$ tariffs offset at least some - if not all — of the U.S. manufacturing competitiveness provided by the Section 201 tariffs (both sets of tariffs are described fully in Section 2 of this report). Because U.S. supply chains do not exist for most PV module components, or do not exist at a scale to supply the PV module industry, importing components subject to Section 301 tariffs was difficult to avoid. Furthermore, uncertainty regarding the scheduled increase of the Section 301 tariff rate hindered the sourcing of components affected by the tariffs; supplier quotes include tariff costs, so suppliers required an extra payment in case of a tariff increase. Most firms mentioned that the 2018 decrease in the U.S. corporate tax rate made a stronger financial case for adding U.S. manufacturing, although most also said they were already exploring the option before the tax rate reduction was anticipated. The majority of firms indicated that local incentives (such as tax benefits or labor availability) were considered in their selection of a manufacturing site, but many indicated that similar local financial incentives were available at all locations under consideration.

- Access to capital. Several firms cited access to capital as a primary challenge when expanding U.S. manufacturing. Larger firms often financed their expansions internally, whereas smaller firms had more challenges accessing capital.

\footnotetext{
${ }^{10}$ These statements were made by firms in March and April of 2019, when the Section 301 tariffs were $25 \%$ for Lists 1 and 2, and 10\% for List 3. List 4 did not exist yet. Rates have changed since then and are partially documented in Section 2.
} 
- Competition with scale. Some smaller firms expressed concern that larger firms may not need their U.S. facilities to be profitable, which would limit the smaller firms' ability to compete and influenced their decision to expand in the United States. Similarly, many firms communicated that competing with or avoiding the need to import Asian PV components (e.g., cells, modules, cover glass) is challenging owing to the larger scale of Asian manufacturers and their lower reliance on profit margins.

\subsection{Auxin Solar}

Auxin Solar is a California-based, American-owned company founded in 2008 and one of the few OEMs producing PV modules in the United States. As an OEM supplier, Auxin primarily produces modules for other brands, although approximately $10 \%$ of its production is labeled Auxin (Pickerel 2018b). The company reported that one of its key markets is supplying projects with made-in-USA requirements. It also produces modules for other non-standard commercial markets, such as bifacial modules, building-integrated PV, modules for non-terrestrial applications, and custom-size modules (Pickerel 2017b). Auxin Solar has noted that focusing on these types of markets enables the company to compete on price and speed. For example, it can switch output from regular to bifacial modules, or from 60-cell to 72-cell modules, in about 2 hours (Pickerel 2018b). In mid-2017, Auxin was operating at an annual production capacity of roughly $0.1 \mathrm{GW} /$ year (Pickerel 2018b, 2017b).

\section{Expansion plans}

The Auxin Solar facility in San Jose, California, has room for expansion. Its annual production grew from about $0.1 \mathrm{GW} /$ year in mid-2017 to $0.15 \mathrm{GW} /$ year in late 2018 (Pickerel 2018b, 2017b). If fully built out, its facility could produce about $0.6 \mathrm{GW}$ annually (Pickerel 2017b). As of early 2019 , the company reported that excess space was used for warehousing.

At an annual production rate of $0.15 \mathrm{GW} /$ year in early 2019, Auxin employed 60 people and operated two shifts, six days per week (Pickerel 2018b). This translates into a labor intensity of around 400 employees per GW/year of module capacity, which is relatively low by industry standards, especially given its relatively small production scale. The company reports that this is due to their production equipment (which is somewhat automated), minimization of administrative overhead, and the lack of sales/marketing expenses incurred as an OEM.

Auxin Solar stated that it has explored creative partnerships with other firms to provide capital for expansion, given its limited access to capital. For example, in 2018 Auxin began negotiations with a roofing material supply company to install a dedicated $0.15 \mathrm{GW} / \mathrm{year}$ line in Auxin's facility, which would require a \$4-million investment from the roofing company. The partner would provide the capital to purchase and install the new production line and "consign" the equipment to Auxin. Auxin reported that the roofing company would accrue several benefits: 1) it could take depreciation on the equipment; 2) it would have priority on use of the equipment; 3 ) it would get a discount from Auxin; and 4) it would not have any risk of maintaining a manufacturing operation run-rate. In exchange, Auxin would not need to provide any capital for the expansion, and it could use the equipment to produce products for other customers when not in use for the roofing company. However, as of July 2019, Auxin indicated that this agreement had not moved forward, primarily owing to uncertainty surrounding U.S. trade policy. 


\section{Proximity to demand}

Auxin Solar stated that, as a U.S.-based company focused on serving U.S. markets, local demand has been a key factor in driving its production level. The company reported that a primary driver has been supplying markets with made-in-USA requirements. It also reported that specialty markets, where pricing is higher, and its flexible manufacturing environment enable it to react quickly to new opportunities and changing customer needs. In addition, Auxin noted that operating as an OEM supplier has enabled the company to develop supply contracts with different brands and distribute demand throughout the year. This strategy has made the firm more resilient and less susceptible to seasonal fluctuations (Pickerel 2018b).

\section{Tariffs and other incentives}

When the Section 201 tariffs were being debated, Auxin Solar advocated for a 30\% tariff; at the time, it used internal analysis of its cost structure to estimate that a $30 \%$ tariff would enable it (and other U.S. firms) to compete with imports yet be small enough to not hurt the U.S. market substantively. Auxin subsequently reported that, broadly, the Section 201 tariffs have helped the company remain competitive in the U.S. market. However, Auxin also mentioned some challenges, including the subsequent drop in module prices after the Section 201 tariffs were enacted (commonly attributed to the reduction in China's solar subsidies in May 2018), the loss of some opportunities in the small-panel off-grid market due to tariff exemptions, and again in the bifacial market due to exemptions. Auxin described these bifacial exemptions as a major concern, because - as the benefits of the Section 201 tariffs decline year over year - the company anticipates losing business in standard modules and therefore has shifted focus to bifacial production. Auxin noted that it generally views any Section 201 exemptions as either a loss of that market segment for itself and/or a potential loophole around the 2019 remedies for foreign imports.

Auxin reported experiencing challenges importing cells, because suppliers have been concerned they will be subject to unanticipated tariffs after the point of sale if the $2.5 \mathrm{GW} /$ year cap is unknowingly surpassed prior to the point of sale. As a result, when placing orders in 2019, Auxin mentioned they were required to place additional funds into a temporary account for the supplier in case it is later determined that the order was processed immediately after the cap was surpassed, in which case tariffs would be applied retroactively and paid by the supplier. Auxin may or may not get these funds back, but it stated that the extra expense and uncertainty make planning difficult. Furthermore, Auxin reported that it has been particularly impacted by the Section 201 exemption issued for custom-sized modules. The company said that this is one of its key market segments, and granting this exemption has hindered its ability to compete against Asian imports in the segment.

In contrast to its views on the Section 201 tariffs, Auxin reported that the Section 232 and 301 tariffs have been clearly negative for the company. As of March 2019, Auxin estimated that the Section 232 and 301 tariffs completely offset the advantages introduced by the Section 201 tariffs. The company estimated that the Section 232 and 301 tariffs increased its material costs by roughly $32 \%$, because most BoM items were unavailable (or unavailable at a competitive price) from non-Chinese suppliers. Thus, most BoM items were subjected to the Section 232 and 301 tariffs. For example, Auxin estimated paying 25\% duties on backsheets, glass, sealants, EVA, 
and junction boxes. Compounding duties on aluminum due to Section 232 and earlier tariffs gave imported tabbing ribbon and aluminum even higher tariff rates. Furthermore, Auxin said it has been subject to additional customs inspection fees related to Section 301 that apply to importing shipping containers, including \$300 per container for $\mathrm{x}$-rays, $\$ 1,000$ per container for manual inspection, and $\$ 200$ per container for warehousing. These additional fees amounted to roughly $\$ 1.5$ per sheet of glass based on 1,000 sheets of 72-cell-size glass per container, or about 0.5 cents/W.

\section{Component and material sourcing}

Auxin Solar noted that, historically, it has used a mix of domestically sourced as well as imported items. Yet, as of early 2019, it stated that most of its components and materials were imported, although it was aggressively researching alternate BoM vendors as well as performing R\&D and recertifying products. It described sourcing in early 2019 as shown below:

- Cells - primarily from Taiwan and Germany

- Backsheets - imported (previously sourced from U.S. supplier, evaluating a new supplier as of March 2019)

- EVA—some domestic, some imported

- Ribbon/aluminum-imported

- Sealant-imported

- Flux-U.S. supplier

- Glass - imported. Auxin recently identified a potential U.S. supplier, but it encountered two obstacles. First, Auxin would need to order 6 months of supply at a time in order to obtain reasonable pricing, because the supplier would need to briefly modify its process and produce a certain amount to make the switch economical. Auxin noted that this would not be compatible with its fluctuations in monthly demand for glass products based on which specialty PV it is producing. Second, Auxin would need to get the glass tempered by another company, which would add time and expense.

- Stringer equipment - imported from Europe. Auxin recently purchased Chinese stringer equipment, but it did not last; it had a useful lifetime of less than 2 years. Previously, Auxin imported equipment from Japan and Germany that lasted 10 or more years.

- Automated capacitance-voltage profiler-Europe

- Automated harness machine-Europe

- Laminator - in process of sourcing from Japan

\section{Looking forward}

Auxin Solar reported that it was continuing to plan for and seek opportunities to expand production. The company had developed internal plans for a further $0.125 \mathrm{GW} /$ year expansion that could be executed relatively quickly. The estimated CapEx required to implement this level of expansion would be $\$ 3.5$ million, or $\$ 0.028 / \mathrm{W}$ of annual capacity. Auxin developed plans for adding up to four parallel lines in its existing San Jose facility that could expand production by up to $0.45 \mathrm{GW} /$ year. The company estimated that the lead time to add $0.15-0.2 \mathrm{GW} /$ year of 
capacity is about 6 months. It also estimated that the CapEx to build a $0.5 \mathrm{GW} /$ year fully automated line from Italy would be $\$ 12$ million, or $\$ 0.024 / \mathrm{W}$ of annual capacity. However, Auxin reported that its relatively small size - along with uncertainty about PV markets and policies - has constrained its access to capital, and it has been unable to pursue further expansion. Auxin noted that, in the meantime, it will continue to make incremental investments in equipment when affordable.

\subsection{First Solar}

First Solar is a U.S.-based company founded in 1999, after operating as early as 1987 under the name Solar Cells, Inc. It is one of the few thin-film PV manufacturers in the United States and also has manufacturing in Malaysia and Vietnam. First Solar's thin-film PV manufacturing process differs from the c-Si PV paradigm in that the active cell layer is deposited and processed directly on the module's front glass, so module assembly is integrated in the same facility as cell production. This type of module is often referred to as being monolithically integrated.

First Solar is the world's dominant producer of CdTe PV technology, with over 4 GW/year of global manufacturing capacity at the end of 2018 (First Solar 2019a) and over $20 \mathrm{GW}$ of cumulative shipments at the end of 2018 (First Solar 2019b). In 2017, First Solar produced 0.2 GW in its facility in Perrysburg, Ohio, which has a capacity of $0.6 \mathrm{GW} /$ year (SPV Market Research 2019). Production was much lower than capacity because First Solar began upgrading its Perrysburg plant in 2017 to produce Series 6 modules, which are more than triple the size of the previous Series 4 frameless modules and have aluminum frames (Rogers 2018; Strevel 2017). Historically, First Solar has focused on producing PV modules for the utility-scale market. It has operated as a vertically integrated PV company: producing modules, selling modules to other companies, developing turnkey PV powerplants, and performing operations and maintenance.

\section{Expansion plans}

In April 2018, First Solar announced plans to construct a 1.2-GW/year production facility in Walbridge, Ohio, within 5 miles of its Perrysburg facility (Rogers 2018). As of May 2019, the company reported that more than half of the equipment was installed and was being brought online. First Solar expected this new plant to be fully online late in the third quarter of 2019. The target size for this plant was 1 million square feet (Pickerel 2018a). Of all the announced U.S. capacity expansions since 2017 , this was one of only two planned as a greenfield facility.

When fully operational, this new plant is expected to employ 500 workers directly, with an annual payroll of \$30 million (Pickerel 2018a). Thus, the plant is expected to have a labor intensity of about 400 employees per GW/year of capacity — on the low side of labor intensities reported for other U.S. plants, even though it will be manufacturing monolithically integrated modules. Equivalent c-Si ingot production, wafer cutting, and cell and module production would require 2,200-4,500 employees per GW/year, according to an NREL model (Woodhouse et al. 2019). The low labor intensity reflects the self-described highly automated design that First Solar is using to improve the cost-competitiveness of the facility.

The facility's CapEx was roughly $\$ 400$ million (Pickerel 2018a), the highest of any firm examined here on both an absolute and per-GW/year basis ( $\$ 330$ million per GW/year, or 
$\$ 0.33 / \mathrm{W}$ of annual capacity), largely because it manufactures monolithically integrated modules end-to-end. An equivalent CapEx for manufacturing c-Si modules from crystal growth through ingot growth, wafering, cell fabrication, and module assembly would be $\$ 250-\$ 350$ million per GW/year (Smith and Margolis 2019). First Solar mentioned that its position as one of the most financially stable PV firms has enabled it to build a strong cash position. Accordingly, it stated that the Walbridge expansion (and expansion of its Vietnam-based production) was completed via balance-sheet financing. First Solar reported that it has been conservative about taking on debt; it has short-term debt but no long-term debt.

\section{Proximity to demand}

First Solar noted that, historically, the U.S. market has been critical for the company; over 11.5 GW of U.S. PV plants used First Solar PV modules at the end of 2018. First Solar reported expecting more than $7 \mathrm{GW}$ of projects to come online in North America over the next few years (First Solar 2019c). The company also stated that maintaining a significant U.S. manufacturing presence and operating as an American company provides a competitive advantage with regard to demand for made-in-USA products and stronger relationships with U.S. businesses.

\section{Tariffs and other incentives}

First Solar manufactures CdTe PV modules, so it is not subject to Section 201 tariffs, which only apply to c-Si PV cells and modules. Although this could give First Solar an advantage in the U.S. market, it does not incentivize increased U.S. production, because First Solar could import complete modules without incurring the tariffs. First Solar reported that its decision to expand U.S. production (and upgrade its existing Perrysburg facility to Series 6) was driven by a desire to strengthen its U.S. position, stay competitive in the U.S. market, and be closer to demand, as opposed to being primarily motivated by federal tariff-related policy changes - though these changes were viewed as supportive and leveling the playing field with respect to industrial policy and trade practices in China. However, First Solar also noted that the exemption of bifacial c-Si modules from the Section 201 tariffs (which the company anticipates will be the mainstream c-Si PV technology in the future) substantially reduced any commercial advantages the Section 201 tariffs may have represented to First Solar.

The more recent Section 232 and 301 tariffs, however, have partially offset the benefits of the Section 201 tariffs according to First Solar, particularly for its Series 6 modules with aluminum frames. First Solar observed that the Section 232 and 301 tariffs had an unintended impact on the pricing of aluminum and glass from U.S. suppliers: historically, U.S. aluminum and glass were more expensive than imports even when accounting for shipping costs, but - since the Section 232 and 301 tariffs were enacted - U.S. aluminum and glass suppliers have increased their prices just to the point at which they remain competitive with post-tariff imports.

First Solar noted that changes in U.S. corporate tax rates at the federal level also played a very significant role in the company's U.S. expansion. Its management highlighted the lower tax rate to make the case to its board and shareholders that the Walbridge facility would be economical. First Solar stated that, without this change in federal policy, it is unlikely it would have proceeded with the expansion. 
First Solar indicated that local incentives played a smaller role. For example, local incentives offered to First Solar for building the Walbridge plant included a property tax exemption for 15 years and a $2.267 \%$ credit on commercial activity taxes (Limpf 2018). However, First Solar agreed to pay approximately $\$ 900,000$ annually to the local school district in lieu of property taxes (Limpf 2018). First Solar also considered locating in Michigan and Indiana (Limpf 2018), but ultimately the company decided the benefits of co-locating with its existing Ohio plant were superior to additional incentives it could have received from other jurisdictions.

First Solar also reported that the decision to locate in Ohio was driven by the expectation of increased automation for Series 6 production. The initial lines required more labor than originally expected, but First Solar is aiming to increase throughput, and it expects the labor intensity to decline over time.

\section{Component and material sourcing}

First Solar indicated that, historically, it has used a mix of domestically sourced and imported items, and it continues to use a mix:

- Conductive-adhesive busbar-one domestic supplier, one Asian supplier

- Interlayer-China

- Aluminum-U.S. supplier

- Glass-U.S. front glass supplier, commodity back glass imported

\section{Looking forward}

First Solar reported plans to continue expanding its PV manufacturing capacity globally, noting its Series 6 module technology is technologically differentiated and superior to its Series 4 modules. According to the company, continued growth in PV manufacturing is necessary for maintaining its competitive position in the PV industry. In short, First Solar stated that it was prioritizing growth over short-term profits to reduce manufacturing costs, gain market share, and continue operating as the smaller competition exits the market. In First Solar's view, the global $\mathrm{PV}$ industry is in a shakeout period during which only the largest-scale, lowest-cost manufacturers will survive.

\subsection{Hanwha Q Cells}

Hanwha Q Cells is a South Korean company with manufacturing facilities in South Korea, Germany, Malaysia, and China. Its roots go back to 1999 with the founding of Q Cells in Germany. Hanwha acquired Q Cells in 2012. After acquiring several other PV companies, it formally consolidated its PV holdings into Hanwha Q Cells in 2015. With cell and module production capacities of $8 \mathrm{GW} /$ year, Hanwha Q Cells was one of the world's largest PV manufacturers in 2017. It produces a range of c-Si modules targeted at the residential, commercial, and utility-scale markets. It has been expanding rapidly, particularly with regard to its mono-PERC module production.

\section{Expansion plans}


In May 2018, Hanwha Q Cells announced plans to build a $1.6 \mathrm{GW} /$ year module production facility in Dalton, Georgia (Parnell 2018). The Dalton facility started shipping modules in February 2019, and, as of April 2019, Hanwha Q Cells expected the plant to reach its full production capacity (now estimated at $1.7 \mathrm{GW} /$ year) by the end of the year. ${ }^{11}$ The building was planned to be 300,000 square feet (Flessner 2018). Of all the announced U.S. capacity expansions since 2017, this was one of only two planned as a greenfield facility.

Hanwha Q Cells stated that the Dalton facility was specifically designed to produce mono-PERC modules with half-cut cells. It will produce both 72-cell-equivalent mono-PERC modules with 144 half-cut cells for utility and commercial applications, and 60-cell-equivalent mono-PERC modules on black backsheets with 120 half-cut cells for residential applications.

The Dalton facility employs more than 750 people near full capacity (Oliver 2019), for a labor intensity of 420 employees per GW/year of module capacity - the third lowest of the firms reported here. It is assumed that the facility's scale and state-of-the-art automated production equipment contribute to its low labor intensity.

Hanwha Q Cells reported that the CapEx for the factory totaled roughly $\$ 160$ million, including the building and all new production equipment, yielding a CapEx intensity just under $\$ 100$ million per GW/year, or $\$ 0.10 / \mathrm{W}$ of annual capacity. This CapEx intensity is higher than that of LG's plant in Alabama, which at $0.5 \mathrm{GW} /$ year of capacity is the most similar to the Hanwha $\mathrm{Q}$ Cells facility in terms of size and technology. Whereas the Hanwha Q Cells facility included a new building and all new equipment, the LG facility used an existing building and some used equipment.

Hanwha Q Cells noted that, because the United States is a relatively expensive manufacturing location, it built a large plant to pursue cost-competitiveness through economies of scale with respect to manufacturing equipment, labor, and materials.

\section{Proximity to demand}

During the past few years, the United States has been one of the largest markets for Hanwha Q Cells module sales, and the company has been one of the largest module suppliers to the U.S. market. The firm has historically gained significant U.S. market presence through large utility contracts (Parnell 2018; Osborne 2017a). The Dalton facility is already contracted to supply more than 335,000 panels for a $\$ 150$ million investment by the Silicon Ranch Corporation (the solar subsidiary of Shell), which will sell power to electric membership corporations in Georgia, most of which will support a Facebook data center (Owens 2019). This project is expected to be at least $0.1 \mathrm{GW}$ and may exceed $0.13 \mathrm{GW}$. Hanwha Q Cells said that it expects the Southeastincluding Georgia, Florida, Texas, and North Carolina - to lead the United States in PV demand growth over the next 5 years. According to the company, the proximity to growing U.S. demand was the primary factor in its U.S. expansion decision.

\section{Tariffs and other incentives}

\footnotetext{
${ }^{11}$ The Hanwha Q Cells location in Georgia had its grand opening in September 2019 at a finished capacity of 1.7 GW/year.
} 
Hanwha Q Cells received \$30 million in incentives from Whitfield County including free land, reduced property taxes, job tax credits, and training assistance through the Georgia Quick Start program (Weaver 2018a; Flessner 2018). In addition, Hanwha Q Cells mentioned that it located in Georgia in part because the state is one of the least expensive U.S. labor markets, and Dalton is a source of experienced factory workers owing to the continuing impact of the 2008 recession on the city's carpet manufacturing industry.

Hanwha Q Cells also stated that, although planning for the Dalton facility began prior to the Section 201 tariff, this tariff created an incentive to move quickly with the expansion. Furthermore, the company noted that the Section 232 and 301 tariffs reduced some benefits of the Section 201 tariff.

\section{Component and material sourcing}

As a mostly Asian-based manufacturer, Hanwha Q Cells stated that it has historically relied on Asian components and materials, and it planned to import cells from South Korea for its U.S. manufacturing. It also planned to source other items through existing relationships in Asia, but over time it will consider U.S. sources if they are cost and quality competitive.

\section{Looking forward}

Hanwha Q Cells reported that it is constantly seeking financially favorable opportunities to expand module and cell production around the world. The largest driver of the Hanwha Q Cells decision to expand production in the United States was reported to be growing demand in the Southeast, and the company indicated that future expansions will likely focus on similar opportunities.

\subsection{JinkoSolar}

JinkoSolar is a global company headquartered in China with manufacturing facilities in China and Malaysia, as well as the United States as of 2018. It started as a wafer manufacturer in 2006 and rapidly became one of the largest vertically integrated PV manufacturers in the worldproducing ingots, wafers, cells, and modules. In 2013, JinkoSolar was the ninth-largest manufacturer of PV modules, with $1.5 \mathrm{GW} /$ year of production. In 2018, it was the world's largest PV manufacturer, with over $10 \mathrm{GW} /$ year of module production capacity and $7 \mathrm{GW} / \mathrm{year}$ of cell production capacity (SPV Market Research 2018). Although JinkoSolar began by manufacturing multicrystalline PV, since 2015 it has rapidly shifted into mono-PERC module production, with an 85\% product share in 2019 (Colville 2019).

\section{Expansion plans}

In March 2018, JinkoSolar announced plans to build a $0.4 \mathrm{GW} /$ year module manufacturing facility in Jacksonville, Florida (Brune Mathis 2018b). JinkoSolar reported that, in order to move quickly, it used an existing vacant building and purchased all new equipment. Pilot production began in November 2018 (Brune Mathis 2018a), and a formal opening ceremony was held in February 2019. In May 2019, JinkoSolar noted that the facility was fully equipped and staffed. 
JinkoSolar described plans to assemble mono-PERC modules in the Jacksonville facility using cells made in Malaysia. However, it will use non-standard $158.75-\mathrm{mm}$ by $158.75-\mathrm{mm}$ cells (Roselund 2018a). These dimensions produce slightly larger modules and higher output per module. JinkoSolar reported that it has moved all its mono-PERC production toward this larger cell size.

The company noted that its Jacksonville facility is highly automated, with advanced manufacturing features such as artificial intelligence at certain stations. The firm emphasized that this approach was important for enhancing local labor capabilities and increasing production speed. The facility was expected to have more than 200 employees when fully operational (Brune Mathis 2018b), for a labor intensity of 500 employees per GW/year of capacity. This labor intensity is around the middle of the range for firms reported here, which corresponds well with the plant size and level of automation.

The company-reported CapEx was approximately $\$ 50$ million, which includes the cost of the building upgrades and all new manufacturing equipment, corresponding to a CapEx intensity of $\$ 125$ million per GW/year or $\$ 0.125 / \mathrm{W}$ of annual capacity. Again, this is around the middle of the range of CapEx intensities for firms reviewed here, which corresponds well with the moderate scale of production and the purchase of all new equipment.

\section{Proximity to demand}

JinkoSolar noted that large agreements to supply modules to utility-scale projects with U.S. firms - including NextEra, Con Edison, and others - played a critical role in its decision to add U.S. manufacturing. JinkoSolar has also been making significant gains in the U.S. residential and commercial markets. For example, its share of the U.S. residential PV market rose from $0.1 \%$ to 8.7\% between 2014 and 2018 (Wood Mackenzie 2019). JinkoSolar's management believes that modules assembled in the Florida facility using cells made in Malaysia will help capture more of the U.S. residential market, which also factored into the firm's decision to establish a factory presence in the United States.

\section{Tariffs and other incentives}

In addition to a desire to locate some capacity closer to U.S. customers, JinkoSolar reported that the Section 201 tariff was a driver in its decision to add U.S. manufacturing capacity, and the temporary nature of the tariff encouraged the firm to move quickly. However, the company also acknowledged that Section 201 and other tariffs created planning challenges.

First, JinkoSolar perceived uncertainty around the exemption process. The company requested an exemption based on its use of non-standard size cells (Roselund 2018a), arguing that an exemption would enable expansion of the Jacksonville facility. As of mid-2019, however, the exemption request had not been granted. Second, the company perceived uncertainty around the potential impact of the $2.5 \mathrm{GW} /$ year cell quota. Although it is unclear whether this cap will be reached in 2019, JinkoSolar expects it is very likely to be reached in 2020. Under the Section 201 tariff structure, once this cap is reached in a given year, additional imported cells are subject to the tariff for the remainder of the year. JinkoSolar explained that new solar cells have an expiring shelf life (they degrade more rapidly before encapsulation); therefore, it is infeasible for 
the company to import $0.4 \mathrm{GW}$ of cells at the beginning of the year to ensure a sufficient tarifffree supply of cells.

JinkoSolar also mentioned that Section 232 and 301 tariffs have complicated U.S. expansion in several ways. First, the Section 301 tariff applied to some of the manufacturing equipment that the company purchased. The Section 301 tariff also applies to most of the non-cell BoM items used to assemble the modules in Jacksonville. Additionally, the Section 232 tariff raised the cost of steel related to upgrading the building containing the manufacturing line. JinkoSolar noted that, together, these factors reduced the benefits it received from the Section 201 tariff.

JinkoSolar explained that its decision to locate its facility in Jacksonville (after evaluating numerous sites in the Southeast) was informed by a combination of local incentives and community characteristics. JinkoSolar received a total of $\$ 3.4$ million in incentives from Florida and Jacksonville, which the company described as similar to the financial incentives offered by all the locations it evaluated. It ultimately chose the Jacksonville location for five main reasons: 1) it is near a deep-water port, which enables easy receipt of shipments from Asia; 2) it is in a business-friendly area with a large labor pool; 3) it has access to domestic transportation networks (Jacksonville has railways and three major highways); 4) Jacksonville is a city and its own county, which simplified the permitting process; and 5) an available empty building enabled the firm to move quickly.

\section{Component and material sourcing}

JinkoSolar noted that, as a global company headquartered in China, it has developed strong relationships with global suppliers including many in China, where the majority of the supply chain exists due to the large annual demand for solar in China. Cells are the one component the firm expects to source from outside China; it will source cells from its factory in Malaysia (Gregorio 2018).

JinkoSolar stated that it has recently tried to identify U.S.-based BoM suppliers, not only because it would be logistically simpler, but also partly in response to the Section 301 tariff. It found, however, that most BoM items are not available from U.S. suppliers or are prohibitively expensive compared to items from overseas suppliers. More broadly, it found that most U.S. firms do not have relevant solar manufacturing experience and lack the capacity, speed, and price to compete with overseas suppliers. For example, JinkoSolar found several potential local suppliers of aluminum extrusions, but the cost was much higher, especially because the suppliers did not have experience creating the solar-specific aluminum frames, and JinkoSolar was not sure if it could rely on these suppliers to deliver the proper specifications at scale and cost competitively. JinkoSolar ultimately made a similar assessment for all other non-cell BoM items, like glass, EVA, and backsheets.

JinkoSolar stated that it has pivoted away as best it can from China-based BoM suppliers owing to Section 301. The company noted that the new suppliers are capable, but costs are higher and new relationships need to be forged.

\section{Looking forward}


JinkoSolar said it expects the $0.4 \mathrm{GW} /$ year Jacksonville plant to increase in capacity as efficiency increases over time, and the company will continue to evaluate options for expanding U.S. module production. However, it does not plan to pursue U.S. cell manufacturing, because cell manufacturing is more complex and time consuming to scale-up.

\subsection{LG Electronics}

LG Electronics is a multinational company with global headquarters in South Korea. LG is best known as a $\$ 54$ billion global innovator in technology and manufacturing with operations in 140 locations around the world and a workforce of more than 74,000. The company designs and manufactures a diverse set of products, from home appliances and consumer electronics to mobile communications and vehicle component solutions. LG has been manufacturing PV products in South Korea since the 1980s. In 2019, LG is known for developing and producing high-efficiency modules intended for residential and commercial applications.

\section{Expansion plans}

In June 2018, LG announced plans to add $0.5 \mathrm{GW} /$ year of PV module manufacturing to its existing campus in Huntsville, Alabama (Pyper 2018). It selected an existing building that had been used for various operations over 30-plus years, including TV assembly, then microwave manufacturing, and then warehousing. Some new PV production equipment was purchased, while other equipment was relocated from South Korea and Germany. LG stated that it had originally planned to use only relocated equipment, but it learned this would likely slow the startup process (because some equipment required certification), so some new equipment was purchased instead. The plant began pilot production around February 2019, with production scaling up as the year progressed (Foehringer Merchant 2019). LG is producing its NeON 260 cell n-type monocrystalline silicon module for residential and commercial applications at the Alabama plant (Pyper 2018).

The Huntsville facility is expected to employ 160 people at full scale (Pickerel 2019a), corresponding to 320 employees per GW/year of module capacity - the lowest labor intensity of the group reported here. The low labor intensity is expected given the relatively large scale of the Huntsville plant and some reliance on new equipment. The total CapEx was \$28 million (Pyper 2018 ), which corresponds to a CapEx intensity of $\$ 60$ million per GW/year or $\$ 0.06 / \mathrm{W}$ of annual capacity, the third lowest of the group for which data are available. This low CapEx intensity is likely due to LG's use of an existing building and reliance on some used equipment.

\section{Proximity to demand}

LG previously stated that, even after its $0.5 \mathrm{GW} /$ year facility comes online, it expects sufficient U.S. demand to require that additional modules be imported (Pickerel 2018b). LG reported being the first- or second-largest supplier to U.S. residential and commercial markets for the past few years. Although the company noted that scaling a U.S. facility to supply all of its U.S. demand would have been prohibitive, it still perceived benefits from establishing a significant mass of production, offering a shorter supply chain to customers and offering made-in-USA products.

\section{Tariffs and other incentives}


LG indicated that the Section 201 tariffs played a role in its decision to open the Huntsville facility. Initially, LG stockpiled some modules when the Section 201 tariffs were announced, but that inventory ran out later in 2018. Unlike most of the other companies studied here, LG reported that the Section 301 tariffs have not been a major challenge.

LG reported that, when considering a U.S. location, it conducted a competitive, multistate search and found similar offerings of incentives across localities, including a sales tax exemption on manufacturing equipment, investment from the state, and a jobs grant from the city. LG stated that the Huntsville location was selected in the interest of time and in part because of its existing vacant building. The specific incentives for the Huntsville location include: 1) receiving $1 \%$ of the $\$ 28$ million investment as a tax deduction for the first 10 years of operation, which translates into roughly $\$ 3$ million of local tax savings over 10 years; 2 ) a payroll tax reduction of $2 \%-3 \%$ if hiring Alabama residents; and 3) \$1,000 for every job created, up to a cap of $\$ 170,000$.

\section{Component and material sourcing}

As of early 2019, LG sourced its cells from South Korea. For the Huntsville plant, it sourced each BoM item such that the Section 301 tariffs were not a major burden. However, the company pointed out that the Section 201 quota on cells is an increasing concern as other U.S. solar plants that rely on imported cells come online.

\section{Looking forward}

Although LG reported no plans for further U.S. expansion of PV manufacturing as of April 2019, the company said it identified other vacant buildings near its Huntsville campus, as well as additional open land on LG property, which could be used to expand PV production in the future. A 310-acre LG site in Clarksville, Tennessee (where LG produced washing machines as of 2019) provides another option for expanding production of $\mathrm{PV}$ and various other products.

\subsection{Silfab}

Silfab is headquartered in Canada as a vertically integrated PV company. Silfab established a manufacturing facility in Mississauga, Canada, in 2010, which has grown to $0.35 \mathrm{GW} /$ year capacity. As of 2019, Silfab manufactured exclusively monocrystalline and bifacial modules, including black-on-black modules, primarily for residential (80\%) and commercial (20\%) applications.

\section{Expansion plans}

In August 2018, Silfab announced it had purchased some assets of Itek Energy, a U.S. company with two facilities in Bellingham, Washington, and a third in Minneapolis, Minnesota (Beetz 2018). The initial published plans were to convert the newest $0.12 \mathrm{GW} /$ year Itek module plant in Bellingham into a $0.35 \mathrm{GW} / \mathrm{year}$ facility, but this estimate was increased in March 2019 to roughly $0.4 \mathrm{GW} /$ year of module capacity expected in mid-2019. The facility was acquired in October 2018, and it was operating at around 0.2 GW/year of capacity in April 2019 (Roselund 2019). 
Silfab reported that the existing $0.12 \mathrm{GW} /$ year line at the Itek facility was retained for monoPERC module production. As of March 2019, the company reported that a second $0.12 \mathrm{GW} /$ year mono-PERC line was being added. In June 2019, a third line manufacturing back-contact metal wrap through (MWT) modules was added with a capacity of $0.12 \mathrm{GW} /$ year initially, with potential to expand to $0.18 \mathrm{GW} /$ year. According to the company, roughly $90 \%$ of the production is expected to be 60 -cell black-on-black modules, for which roughly $80 \%$ of demand comes from the residential sector and $20 \%$ from the commercial sector.

Silfab stated that it retained most if not all of the original 90 Itek employees, and it expected 200 employees when $0.4 \mathrm{GW} /$ year of capacity is achieved, corresponding to a labor intensity of 500 employees per GW/year. However, the company reported having difficulty hiring R\&D staff in Bellingham, where it intends to expand process R\&D. Product R\&D is currently located in Canada.

The total amount invested for the purchase of Itek assets and original plans to expand to 0.35 $\mathrm{GW} /$ year was reported to be $\$ 40$ million (Beetz 2018), corresponding to a CapEx intensity of about $\$ 115$ million per GW/year, or $\$ 0.115 / \mathrm{W}$ of annual capacity. Silfab reported that the investment was not a significant challenge, because the company has been profitable and has a regular banking arrangement supported by partnerships with other companies such as DSM, which mitigates risk and enables Silfab to share resources with other companies.

\section{Proximity to demand}

Silfab stated it was already evaluating U.S. greenfield and brownfield sites before the Section 201 tariffs were enacted, because U.S. demand was strong and Silfab had already expanded to the full capacity possible at its Canadian location. Silfab has also entered into supply contracts with multiple U.S. installers with multistate presences. In June 2018, Silfab entered into a supply contract with PetersenDean, which describes itself as the largest privately owned U.S. roofing and solar company (Silfab Solar 2018a). In October 2018, Silfab contracted with Titan Solar Power to become Titan's exclusive high-efficiency panel supplier, based primarily in the Southwest (Silfab Solar 2018b).

\section{Tariffs and other incentives}

Though Silfab reported that it was already considering U.S. locations when the Section 201 tariffs were announced, it noted that it chose the Bellingham location because it enabled rapid startup. However, Silfab expressed concerns about the $2.5 \mathrm{GW} /$ year cell import cap, because MWT cell suppliers are undergoing rapid technological advances and have limitations in size. Silfab explained that this means it cannot import a full year of cells at the beginning of each year to avoid the tariff cap. Silfab's partner DSM put in an exclusion request for MWT cells in March 2018 that has not yet been ruled on, although Silfab's supply of PERC cells would still carry tariffs if imported past the $2.5 \mathrm{GW} /$ year cap, even if the exclusion were granted.

Regarding the Section 301 and 232 tariffs, Silfab indicated that other tariffs were already in place (e.g., AD/CVD on extruded aluminum from China), which were detrimental to the U.S. business case, but demand was still strong enough to justify a U.S. manufacturing location. Silfab 
estimated that the benefits from a lower U.S. corporate tax rate were grossly outweighed by tariffs on BoM items.

Silfab indicated that it continuously monitors U.S. Department of Energy funding opportunity announcements for funds that may help it further develop its PV technology. Silfab also applied for state support of new technology via the Washington State Department of Commerce "Clean Energy Fund," but stated that ultimately local government incentives were not a major factor in its siting decision. Itek Energy benefited from state incentives for Washington residents to install made-in-Washington PV. However, these incentives will not apply to installations completed after 2021 (Carlson 2017), so Silfab anticipated that supplying its national market through the Itek facility would enable the necessary economies of scale. Silfab mentioned that it was attracted to Bellingham's local labor pool, selecting the Itek facility over Suniva's old Michigan facility because no Suniva employees remained and the Suniva equipment was older and difficult to convert to newer technologies.

\section{Component and material sourcing}

Silfab stated that it has looked for U.S. suppliers but has struggled to identify capable suppliers with both good quality and reasonable costs.

- Cells-MWT and PERC cells from Taiwan and South Korea

- Backsheets - European and Asian supplier

- Glass - imported. Silfab reported that it previously had a glass supplier in Nashville, but that supplier stopped producing solar glass. According to Silfab, there is float glass manufactured in Washington but not pattern glass, which Silfab requires.

- Junction boxes - Chinese and Asian suppliers

\section{Looking forward}

Silfab said it has doubled in size every 2 years. Since starting in Canada in 2010, it has expanded seven times and reached its Canadian facility's full capacity. Silfab reported actively evaluating expansion plans that could allow for additional value-add, for both modules and BoM. The company also reported monitoring the next steps of the USTR and USITC to determine the best market/country to invest in for the future.

\subsection{Solaria}

Solaria is a U.S. company that produces an all-black mono-PERC module using shingled cells. It has a small module manufacturing facility in California with the capability of reaching a 40-MW annual capacity. It also has up to $0.16 \mathrm{GW} /$ year of cell and module manufacturing capacity in South Korea, which is at least partially provided through OEM facilities. Solaria describes its distinctive selling points as having an industry-unique combination of price, performance, and aesthetics.

\section{Expansion plans}

In January 2018, Solaria announced plans for up to $0.2 \mathrm{GW} /$ year of additional module manufacturing capacity globally (Roselund 2018c). This would be in addition to its existing lines 
in California and South Korea. It also planned to increase production at its existing Fremont, California, line to the full $40 \mathrm{MW} /$ year (Groom 2018). It was reported that Solaria had raised $\$ 23$ million from a syndicate of investors to fund the additional $0.2 \mathrm{GW} / \mathrm{year}$ (Roselund 2018c), as well as grow its overall operational capabilities. This would correspond to a CapEx intensity of $\$ 120$ million per GW/year, or $\$ 0.12 / \mathrm{W}$ of annual capacity. Solaria had planned to add 20 U.S.based jobs, in part to reach the full 40-MW/year capacity at its existing facility (Groom 2018), as well as grow its overall operational capabilities.

However, the company explained that the U.S.-based expansion plan was abandoned in 2018 due to the financial burden brought forth by the Section 201 tariffs (Groom 2018). Instead, Solaria effectively ended up adding $0.1 \mathrm{GW} /$ year of module capacity in South Korea through Shinsung E\&G (an OEM) (Solaria Corporation 2019). Solaria reported that it pursued a strategy involving contracted manufacturing in South Korea even prior to the Section 201 tariffs, because the historical risk associated with PV manufacturing investments have hindered PV manufacturers' access to capital for some time.

\section{Proximity to demand}

Solaria indicated that a larger U.S.-based manufacturing location could potentially provide multiple benefits. The company noted that it would enable rapid module production and reduced transit times when meeting domestic demand. It also would enable Solaria to meet made-in-USA requirements for both the consumer and government sectors-for example, Solaria's White Sands project for the U.S. military.

\section{Tariffs and other incentives}

Solaria described challenges related to the Section 201 and 301 tariffs beginning in 2018. It had difficulty acquiring additional working capital owing to uncertainty around future tariffs or policies, such as when the Section $2012.5 \mathrm{GW} /$ year cell cap will be reached, or the Section 301 rate increases. In addition, Solaria found many hidden expenses with the tariffs, including fees for lawyers to ensure compliance and posting higher bonds to freight carriers to mitigate the risk of a future tariff increase based on the percentage of materials imported. Having working capital tied up in bonds greatly reduces the near-term cash-flow critical to growth, according to the company. Solaria emphasized that having reduced working capital due to the Section 201 tariffs has significantly constrained its growth in U.S.-based manufacturing.

Solaria argued that the lower cost of Asia-based products (pre-tariffs) is not just a function of manufacturing costs in those regions, but also of government support for the industry.

Furthermore, the company explained that, with the way the different sets of tariffs interact, U.S. manufacturing for Solaria became less competitive. Solaria said that, if it imports its modules from South Korea with a Chinese frame, the total tariff will be $25 \%$ (due to Section 201). If it manufactures modules in the United States, it pays $25 \%$ in tariffs on cells and has higher BoM costs due to Section 301 tariffs on frames and other items sourced from China. Solaria expected to pay up to $\$ 9$ million in tariffs in 2019, which is more than it will spend on R\&D in 2019.

Solaria expressed that locating some manufacturing in the United States gives it access to U.S. engineering expertise to improve production processes. It also has received U.S. Department of 
Energy awards; its second award was focused on PV manufacturing and helped support the creation of the existing module line in Fremont, California. It also received a $\$ 5$ million lowinterest (2.7\%) loan from the California Energy Commission. In addition, Solaria successfully settled a patent-infringement case against GCL, which restricts GCL from selling its product in the United States and Europe. Solaria explained that protecting IP is paramount given the competitive advantage of its highly differentiated product.

\section{Component and material sourcing}

Solaria noted that it uses cells manufactured overseas because there is no capacity available for purchase in the United States at a competitive price. Because Solaria reported that it was greatly affected by the Section 301 tariffs, it can be assumed that a significant amount of its BoM items are sourced from China.

\section{Looking forward}

Solaria estimated that building a new $0.1 \mathrm{GW} /$ year line in the United States would require \$5$\$ 10$ million in working capital as well as three key policy actions: 1) no tariffs on U.S.-made modules regardless of cell and BoM source, 2) low-interest working capital loans or loan guarantees for U.S. manufacturing, and 3) extension of the investment tax credit (ITC). Solaria indicated that, without these three policy actions in place, the original Section 201 and 301 tariffs make U.S. manufacturing unprofitable for its business.

\subsection{SunPower}

SunPower is a U.S. company, originally incorporated in the United States in 1985 and now majority owned by Total S.A. (a major multinational oil and gas company headquartered in France). SunPower specializes in high-efficiency panels for residential and commercial applications, including interdigitated back-contact cells and shingled options for aesthetic considerations. Its existing manufacturing facilities now include $0.22 \mathrm{GW} /$ year of P-Series module assembly in Oregon, as well as at least $1 \mathrm{GW} /$ year of module capacity in Mexico (Stromsta 2016), 40 MW/year of module capacity in France (Total S.A. 2012), 0.4 GW/year of cell capacity in the Philippines, and $0.8 \mathrm{GW} /$ year of cell capacity in Malaysia (SunPower Corporation 2018a).

\section{Expansion plans}

In April 2018, it was announced that SunPower would purchase the SolarWorld cell and module production facilities in Hillsboro, Oregon (Pickerel 2018c). Under SolarWorld, these facilities had $0.43 \mathrm{GW} /$ year and $0.55 \mathrm{GW} /$ year of cell and module production, respectively. The facilities were officially acquired in October 2018, retooling began in November 2018, and, as of February 2019, the module line was operational at $0.22 \mathrm{GW} /$ year of capacity (Roselund 2018d; Sylvia 2019). SunPower retooled some of SolarWorld's equipment to produce its shingled PERC P-Series modules, which are intended for commercial and industrial applications (Roselund 2018d). Some existing SunPower equipment was shipped from SunPower's location in Mexicali, Mexico (Roselund 2018d). SunPower indicated that, because module assembly requires only one of the multiple buildings located at the Hillsboro facility, as of May 2019 it was planning to sell 
the property (including land and buildings) but lease back the space it occupies for $0.22 \mathrm{GW} / \mathrm{year}$ of module assembly (Rogoway 2019).

The $0.22 \mathrm{GW} /$ year of module capacity was reported to have 200 employees (Sylvia 2019), many of whom were retained from SolarWorld and retrained for module production. This corresponds to a labor intensity of 900 employees per GW/year, which is one of the highest among the firms reported in this work. SunPower reported having about the same level of automation as SolarWorld did.

SolarWorld was purchased for \$30.1 million (Foehringer Merchant 2019), and SunPower indicated it may spend up to an additional $\$ 15$ million on plant upgrades (Rogoway 2018). Basing a CapEx intensity estimate on the $\$ 45.1$ million total investment and $0.22 \mathrm{GW} /$ year capacity results in a value of $\$ 210$ million per GW/year (or $\$ 0.21 / \mathrm{W}$ of annual capacity), which is one of the higher figures reported by the firms covered in this work. However, because SunPower is not using all of the space in the building and perhaps not all of the equipment it purchased from SolarWorld, this CapEx intensity is likely artificially higher than it would be for a typical $0.22 \mathrm{GW}$ line.

Utilization of the additional, unused module assembly capacity at the facility would decrease the CapEx intensity proportionally, or a successful sale of the building (and subsequent partial lease) would allow for a lower CapEx estimate. It was reported that the building itself was purchased for \$26 million (Rogoway 2019). Therefore, the CapEx would be \$19.1 million not including the building price or any costs of leasing building space, which would correspond to $\$ 90$ million per $\mathrm{GW} /$ year, or $\$ 0.09 / \mathrm{W}$ of annual capacity. We may be able to assume that one quarter of the building is used by SunPower, based on the employment ratio of SunPower to SolarWorld (Rogoway 2019). This would correspond to a CapEx of $\$ 25.6$ million and a CapEx intensity of $\$ 120$ million per GW/year, or $\$ 0.12 / \mathrm{W}$ of annual capacity.

\section{Proximity to demand}

SunPower cited strong U.S. demand when discussing the acquisition of the SolarWorld plant, as well as the market for American-assembled panels (SunPower Corporation 2018b). SunPower also noted that being close to demand was a factor in selecting the Hillsboro location.

\section{Tariffs and other incentives}

SunPower publicly stated that it would not have purchased the SolarWorld factory if it had not won the exemption from tariffs on PV modules it imports from the Philippines and Malaysia, noting that the tariffs would have cost SunPower as much as \$2 million per week (Rogoway 2018). SunPower intends to use the savings to help pay for upgrades to the SolarWorld facilities (Rogoway 2018). SunPower commented that it is difficult to make a business case for expanding module-assembly capacity unless the cells are tariff-free, and that the company supports eliminating the imported cells tariff or increasing the existing tariff rate quota from the original $2.5 \mathrm{GW} /$ year to perhaps 4-5 GW/year to ensure a tariff-free cell supply for existing domestic module-assembly facilities.

SunPower noted that, because a U.S. supply chain does not exist for many necessary BoM items for module assembly, the Section 232 and 301 tariffs are essentially unavoidable. With the state 
of the Section 201 and 301 tariffs as of early 2019, SunPower estimated that its complete module was $\$ 0.10-\$ 0.15 / \mathrm{W}$ more expensive than the price of modules from overseas suppliers.

SunPower noted that the lower U.S. corporate tax rate did not benefit them, because the company did not turn a profit in 2018. SolarWorld had received some local tax reductions from Oregon that were dependent on production/staffing levels, which SunPower inherited through the SolarWorld sale price.

\section{Component and material sourcing}

According to SunPower, finding U.S. suppliers for BoM items is challenging, because the supply chain does not exist for many components or existing U.S. suppliers are not competitive with imports.

- Glass-SunPower indicated that all glass is imported because there are no rolled PV glass suppliers in the United States. SunPower suggested a minimum threshold of 2 GW/year of sales needed for a glass company to dedicate a line to PV.

- Aluminum-SunPower evaluated U.S. module frame options, but aluminum is much more expensive in the United States than in Asia. However, SunPower explained that not having a domestic supply chain means longer lead times and cycles of learning. SunPower also noted that the import tariffs for aluminum seem to be the highest.

- Equipment-SunPower reported that it is designing most of its tools in the United States (custom shingling and other tools), but mostly sourcing tools from Asia. The stringer for shingling was sourced in the United States, but the laminator was from China, and most other equipment was from Asia.

\section{Looking forward}

SunPower suggested restoring the ITC to a permanent $30 \%$ (or some other fixed percentage) to reduce policy uncertainty due to "lumpy" PV demand created by changes in the ITC.

\section{Tariff Scenario Analysis}

The analysis in this section is intended to quantify the individual price impacts of each of the tariffs described in this report. This goal differs significantly from existing PV tariff analyses in academic literature. The most recent work (Chen and $\mathrm{Su} 2019$ ) uses game theory to model two international PV supply chains under four different trade regimes and computes the outcomes with respect to demand generation, profit generation, and social welfare. The analysis in (Nguyen and Kinnucan 2019) compares the efficacy of country-specific PV tariffs versus uniform PV tariffs for a number of metrics such as domestic manufacturing, employment, and environmental costs. The research reported in (Sandor et al. 2018) considers projected polysilicon production and trade flows in China, the United States, and the rest of the world as a function of polysilicon tariff magnitude. The work regarding U.S.-China PV tariffs in (Hughes and Meckling 2017) presents an analysis of the societal origins of such trade actions. A graduate dissertation (Sun 2016) presents the effects of policy and markets on the PV industry in China, focusing primarily on Chinese domestic policy but also including analysis of tariffs imposed by the United States and European Union. 
In contrast, this report attempts to benchmark current U.S. tariff effects (as of July 2019) on the pricing of PV modules in the United States, rather than performing a retrospective or forwardlooking analysis. To perform a quantitative analysis of tariff impacts on module pricing, the cost inputs for PV modules must be known with a high degree of detail so that individual tariff rates can be applied to the relevant costs. For this, we rely on published NREL data reporting detailed minimum sustainable prices (MSPs) for mono-PERC cell and module production without any tariffs applied (Woodhouse et al. 2019).

Several scenarios are modeled below to encompass potential interactions among PV-relevant tariffs. The locations under consideration include the United States, a representative non-Chinese Southeast Asian location, and China and Taiwan as major targets of PV trade actions.

\subsection{Input Cost Data}

To model the tariff outcomes, the cost of individual components must first be defined. PV cell and module pricing assumptions for different production locations are listed in Figure 10, which reports MSPs for mono-PERC cell and module production without any tariffs applied (Woodhouse et al. 2019). We adjust all cell prices to reflect wafer sourcing from low-cost Asian countries like China or Malaysia. All cells and modules are assumed to be mono-facial with the exception of the fourth bar, which shows the bifacial mono-PERC pricing estimated for the first half of 2018. We assume gross margins of $28 \%$ across all scenarios, where the operating margin is assumed to be $15 \%$. This generates the MSPs calculated in our cost model. It does not necessarily reflect the market price of these goods, because it is meant to be a bottom-up cost model based on sustainable margins. For example, as of July 2019, our bottom-up cost model produced module MSPs that were 30\% higher than market pricing (Feldman and Margolis 2019). However, MSPs are used because it is otherwise challenging to get high-resolution detail on the cost components of current market pricing. 


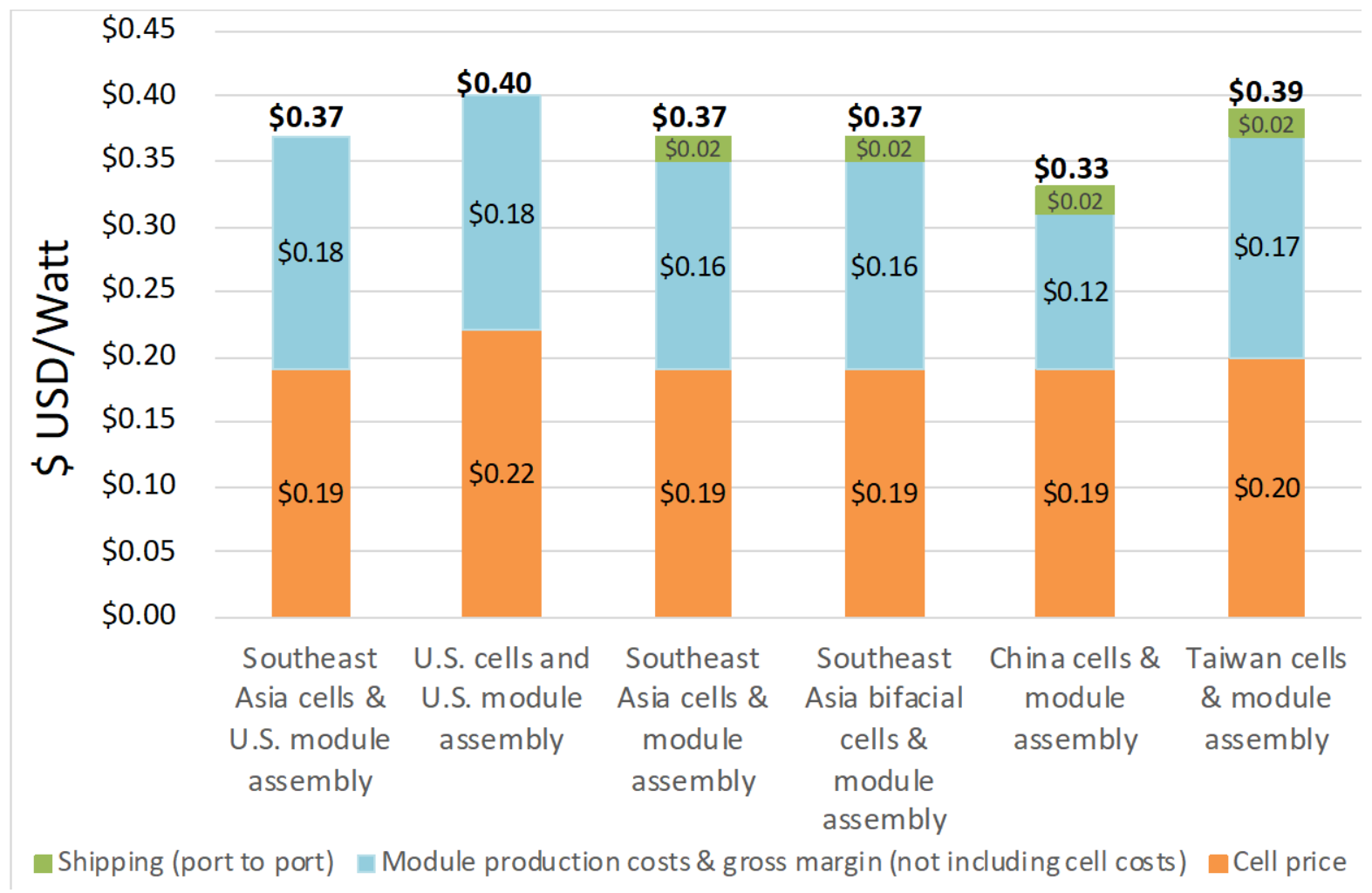

Figure 10. Mono-PERC cell and module price assumptions by production region, without tariffs

The first production scenario in Figure 10 assumes that module assembly occurs in the United States using cells imported from Southeast Asian countries other than China or Taiwan. This scenario represents the price for U.S. module production assuming imported cells but no cell tariffs as a best-case scenario, because U.S. cell production is very limited and cell imports are necessary. The remaining five prices shown in Figure 10 assume both cell production and module production occur in the same country, where "Southeast Asia" represents low-cost Southeast Asian countries specifically not including China or Taiwan.

For simplicity, the data in Figure 10 assume that BoM items have the same prices (not including tariffs) in all locations, although this is unlikely owing to the scale of the supply chain, market structure, and government incentives in China (Zhao et al. 2013). The BoM cost is quantified in Figure 11, again based on NREL analysis (Woodhouse et al. 2019). 


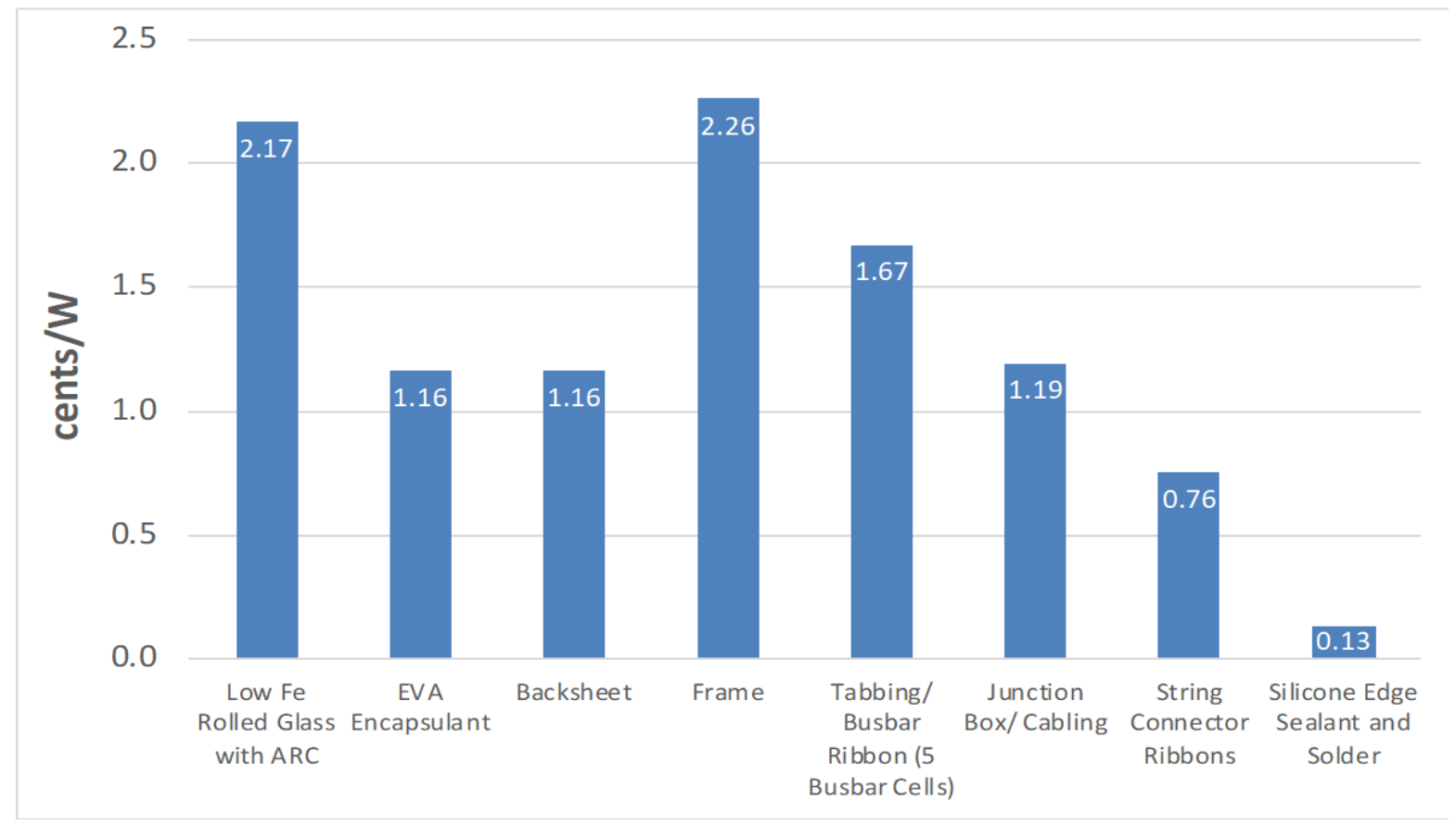

Figure 11. Price assumptions for BoM items

\subsection{Scenarios}

Possible sourcing configurations are listed in Table 9. The scenarios in Table 9 are meant to provide a range of possible combinations of sourcing, but certain combinations are more common than others. For example, U.S. imports of modules from China have shrunk considerably over the past few years, as shown in Figure 12 (U.S. Energy Information Administration 2018), while U.S. cell production dropped below $0.2 \mathrm{GW}$ in 2018 (Wood Mackenzie Power \& Renewables and SEIA 2019) and a significant amount of U.S. cells is being exported to the Philippines (Tsanova 2019). Furthermore, it seems unlikely that new cell capacity will be built in the United States, because cell capacity typically takes multiple years to build, and, by the time the facility would be operational, the benefits of Section 201 would have almost expired. However, these scenarios are included to illustrate the variety of possible tariff outcomes.

Scenario 5 is highlighted in this table, because it represents the most common scenario for U.S. module production; U.S. cell production is very limited, so cell imports are typically necessary. It is likely that some combination of Chinese and non-Chinese BoM items is typically used, and this can be captured by evaluating scenarios $5 \mathrm{a}$ and $5 \mathrm{~b}$. Module prices from each of the other scenarios are compared to scenario 5, which serves as a baseline to evaluate implications for U.S. PV manufacturing. Again, all prices are based on NREL data (Woodhouse et al. 2019). 
Table 9. Sourcing Configurations for Tariff Analysis (baseline U.S. module production scenarios highlighted)

\begin{tabular}{|c|c|c|c|c|c|}
\hline & \multicolumn{2}{|c|}{ Scenario \# } & Cell Sourcing & $\begin{array}{l}\text { Module } \\
\text { Assembly }\end{array}$ & BoM Sourcing \\
\hline \multirow{5}{*}{ 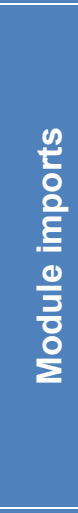 } & \multicolumn{2}{|c|}{ 1: Chinese module } & China & $\begin{array}{l}\text { China } \\
\text { (AD/CVD \& } \\
\text { Section 301) }\end{array}$ & Avoids Section 301 \\
\hline & \multicolumn{2}{|c|}{ 2: Southeast Asian module } & Southeast Asia & Southeast Asia & Avoids Section 301 \\
\hline & \multicolumn{2}{|c|}{$\begin{array}{l}\text { 2a: Bifacial Southeast Asian } \\
\text { module }\end{array}$} & Southeast Asia & Southeast Asia & Avoids Section 301 \\
\hline & \multicolumn{2}{|c|}{$\begin{array}{l}\text { 3: U.S. cells, Chinese } \\
\text { module assembly }\end{array}$} & $\begin{array}{l}\text { U.S. (avoids } \\
\text { module tariff) }\end{array}$ & $\begin{array}{l}\text { China } \\
\text { (AD/CVD \& } \\
\text { Section 301) }\end{array}$ & Avoids Section 301 \\
\hline & \multicolumn{2}{|c|}{$\begin{array}{l}\text { 4: U.S. cells, Southeast } \\
\text { Asian module assembly }\end{array}$} & $\begin{array}{l}\text { U.S. (avoids } \\
\text { module tariff) }\end{array}$ & Southeast Asia & Avoids Section 301 \\
\hline \multirow{8}{*}{ 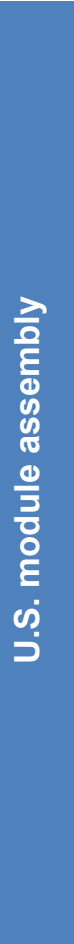 } & \multirow{2}{*}{$\begin{array}{l}\text { 5: Southeast } \\
\text { Asian cells }\end{array}$} & $\begin{array}{l}\text { a) Non- } \\
\text { Chinese } \\
\text { BoM }\end{array}$ & Southeast Asia & U.S. & Southeast Asia \\
\hline & & $\begin{array}{l}\text { b) Chinese } \\
\text { BoM }\end{array}$ & Southeast Asia & U.S. & $\begin{array}{l}\text { China (Section } 301 \\
\& \text { AD/CVD) }\end{array}$ \\
\hline & \multirow{2}{*}{$\begin{array}{l}\text { 6: Chinese } \\
\text { cells }\end{array}$} & $\begin{array}{l}\text { a) Non- } \\
\text { Chinese } \\
\text { BoM }\end{array}$ & $\begin{array}{l}\text { China } \\
\text { (AD/CVD \& } \\
\text { Section 301) }\end{array}$ & U.S. & Southeast Asia \\
\hline & & $\begin{array}{l}\text { b) Chinese } \\
\text { BoM }\end{array}$ & $\begin{array}{l}\text { China } \\
\text { (AD/CVD \& } \\
\text { Section 301) }\end{array}$ & U.S. & $\begin{array}{l}\text { China (Section } 301 \text { \& } \\
\text { AD/CVD) }\end{array}$ \\
\hline & \multirow{2}{*}{$\begin{array}{l}\text { 7: Taiwanese } \\
\text { cells }\end{array}$} & $\begin{array}{l}\text { a) Non- } \\
\text { Chinese } \\
\text { BoM } \\
\end{array}$ & $\begin{array}{l}\text { Taiwan } \\
\text { (AD/CVD) }\end{array}$ & U.S. & Southeast Asia \\
\hline & & $\begin{array}{l}\text { b) Chinese } \\
\text { BoM }\end{array}$ & $\begin{array}{l}\text { Taiwan } \\
\text { (AD/CVD) }\end{array}$ & U.S. & $\begin{array}{l}\text { China (Section } 301 \& \\
\text { AD/CVD) }\end{array}$ \\
\hline & \multirow{2}{*}{ 8: U.S. cells } & $\begin{array}{l}\text { a) Non- } \\
\text { Chinese } \\
\text { BoM }\end{array}$ & U.S. & U.S. & Southeast Asia \\
\hline & & $\begin{array}{l}\text { b) Chinese } \\
\text { BoM }\end{array}$ & U.S. & U.S. & $\begin{array}{l}\text { China (Section } 301 \text { \& } \\
\text { AD/CVD) }\end{array}$ \\
\hline
\end{tabular}

The following assumptions and methods are used to analyze the scenarios defined in Table 9:

- Section 201 tariffs are modeled for the February 7, 2019, through February 6, 2020, interval with duty rates of $25 \%$.

- The Section 301 tariffs on the third list of items are set at $25 \%$, but a later subsection considers the results if the third list had remained at $10 \%$.

- Any scenarios affected by AD/CVD rates are modeled at an upper and lower bound.

- Any scenarios involving imports of cells to the United States are modeled twice: both above and below the $2.5 \mathrm{GW} /$ year cell import quota. 
- Aluminum frames are classified under the 7616 HTS code, and junction boxes are classified under the 8544 HTS code.

- Tabbing, busbars, and string connector ribbons from China are assumed to have a List 3 Section 301 tariff only.

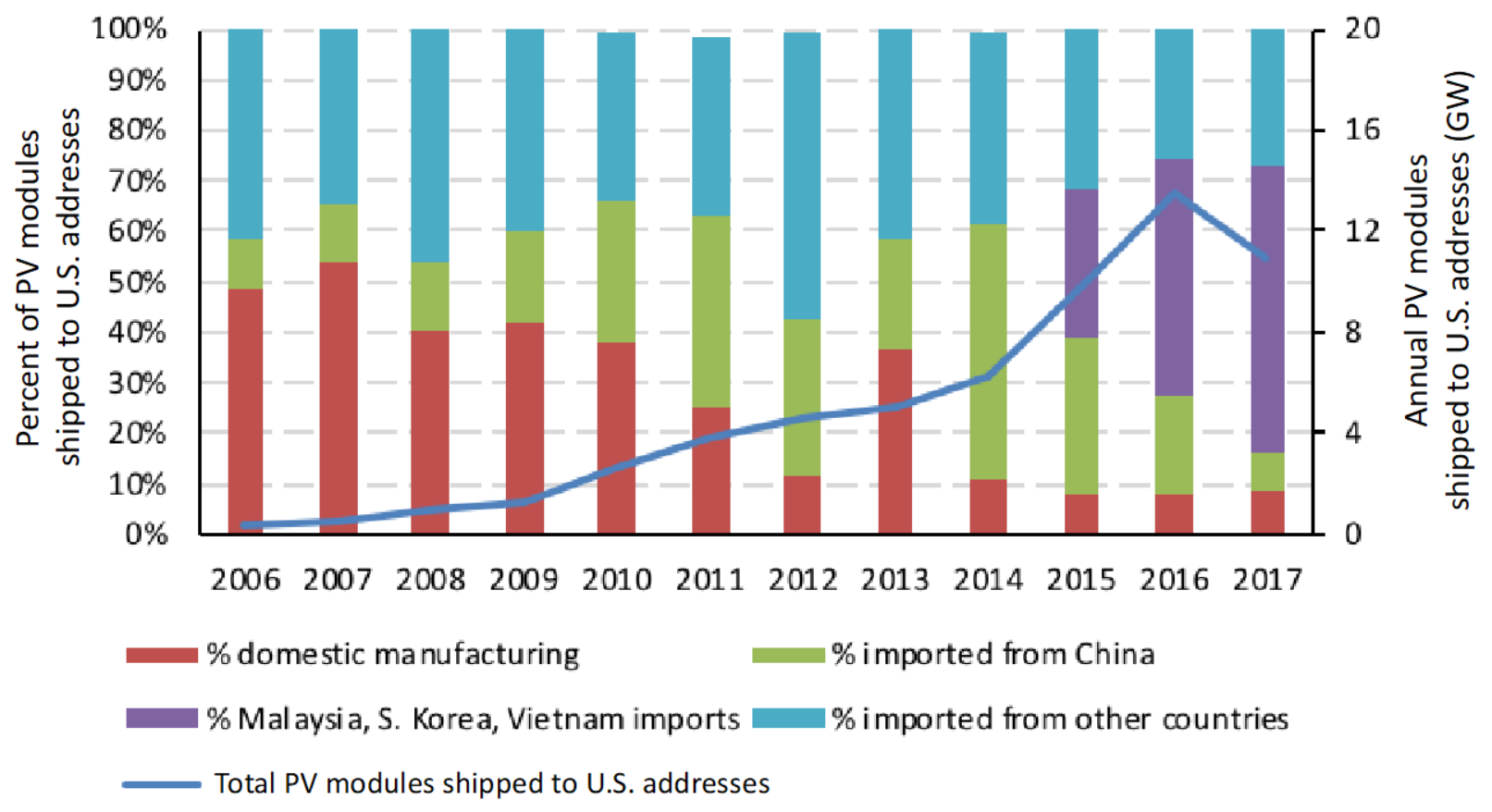

Figure 12. Sourcing of annual U.S. PV module shipments by country, 2006-2017

"Percent of PV modules shipped to U.S. addresses" includes the change in year-end U.S. module inventory in the denominator. 2006-2009 values also include PV cell shipments.

\subsection{Results}

The results are reported as MSPs, which do not necessarily reflect the market prices of these goods, because they are from a bottom-up cost model based on sustainable margins. For reference, as of July 2019 our bottom-up cost model produced module MSPs that were 30\% higher than market pricing (Feldman and Margolis 2019). However, MSP results are used because it is otherwise challenging to get high-resolution detail on the cost components of current market pricing. The results in this section are grouped into three sets of figures:

1. Figure 13 shows a detailed breakdown of scenario 5 .

2. Figure 14 compares imports of modules, including modules containing U.S. cells.

3. Two figures compare U.S.-produced modules:

$\circ$ Figure 15 compares scenarios $5 \mathrm{~b}, 6 \mathrm{~b}, 7 \mathrm{~b}$, and $8 \mathrm{~b}$

Figure 16 compares scenarios $5 \mathrm{a}, 6 \mathrm{a}, 7 \mathrm{a}$, and $8 \mathrm{a}$

\subsubsection{Baseline U.S. Module Scenario}

In order to evaluate the outcomes of all tariff scenarios, a baseline must be established for comparison. Given that a goal of the tariffs is to support U.S. PV manufacturing, it is necessary to establish the price of U.S. PV modules and then compare the price to those produced in various tariff scenarios. Most U.S. PV manufacturing is module assembly, with very limited cell 
production. Thus, the baseline includes importing the lowest-cost cell and performing module assembly in the United States. Because some BoM items are only available from Chinese suppliers while others can be sourced elsewhere, we compare a price with no Chinese sourcing as well as the cost of sourcing individual components from China. The cell pricing, module pricing, and BoM cost data are from NREL (Woodhouse et al. 2019), while each of the tariffs was calculated individually for this report.

Figure 13 shows these price comparisons. The leftmost bar represents the module price for scenario 5a, namely importing a low-cost cell from Southeast Asia before the $2.5 \mathrm{GW} /$ year import threshold for the Section 201 cell tariffs is reached and assembling the module in the United States. This first bar assumes all BoM items are sourced from countries other than China with similar pricing (general duties are assumed to be negligible). This corresponds to a total module price of $\$ 0.37 / \mathrm{W}$, which matches the first bar in Figure 10. The second bar in Figure 13 shows U.S. module assembly using Southeast Asian cells imported after the $2.5 \mathrm{GW} /$ year threshold has been reached, so a tariff of $25 \%$ is applied to the value of the cell, which corresponds to approximately 5 cents and raises the total module price to $\$ 0.42 / \mathrm{W}$. For this bar, all BoM items are assumed to be sourced from countries other than China at similar pricing (general duties are assumed to be negligible). However, because many BoM items are not available from U.S. suppliers or any other suppliers outside of China, the tariffs on each of the individual components must also be evaluated.

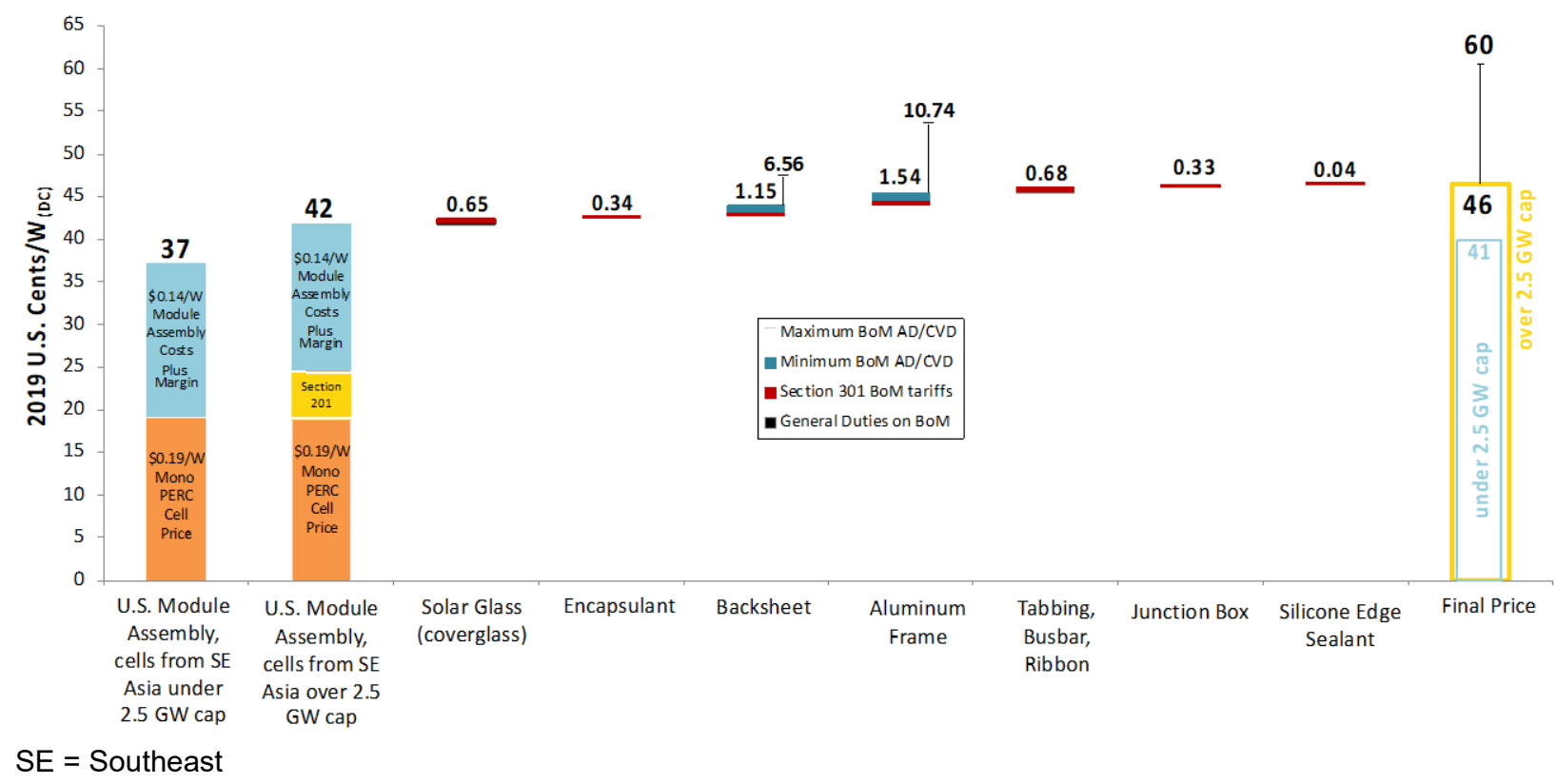

Figure 13. Module prices for U.S. module assembly, including individual tariffs on imported cells and BoM items

The values shown to the right of the first two bars in Figure 13 show the individual tariffs on each of the major BoM items. These assume a 25\% rate for the third list of the Section 301 tariffs. The total value of general duties on the BoM items sums to less than half a cent per watt. However, the Section 301 tariffs sum to 2.6 cents/W, while the AD/CVD tariffs are at least 1.7 cents/W and may be as high as 14.6 cents/W, depending on the supplier. The rightmost bar shows the module price corresponding to scenario $5 \mathrm{~b}$, which is the same as $5 \mathrm{a}$ except all BoM 
items are sourced from China. This totals to a module price of $\$ 0.41 / \mathrm{W}$ to $\$ 0.46 / \mathrm{W}$ with the lowest-possible $\mathrm{AD} / \mathrm{CVD}$ rates, depending on whether cells are imported below or above the 2.5 $\mathrm{GW} /$ year cap. At the highest $\mathrm{AD} / \mathrm{CVD}$ rates when cells are imported above the $2.5 \mathrm{GW} /$ year cap, the module price could be up to $\$ 0.60 / \mathrm{W}$.

\subsubsection{Imports of Modules}

Figure 14 compares the total price (including all tariffs) of imported modules from China and the Southeast Asian region, either containing local cells or cells imported from the United States. The module pricing data shown in blue are from NREL (Woodhouse et al. 2019), while each of the tariffs was calculated individually for this report. The total price ranges from $\$ 0.37 / \mathrm{W}$ for imports of bifacial modules from Southeast Asia to $\$ 1.07 / \mathrm{W}$ for Chinese imports with the upper bound of $\mathrm{AD} / \mathrm{CVD}$ rates.

Imports from non-China Southeast Asian countries perform significantly better compared to some situations in Figure 13. Importing a bifacial module from Southeast Asia is equivalent to assembling a module in the United States using Southeast Asian cells even before the 2.5 $\mathrm{GW} /$ year cell import threshold $(\$ 0.37 / \mathrm{W}$ vs. $\$ 0.37 / \mathrm{W})$. Importing a mono-facial module from Southeast Asia containing U.S. cells avoids all tariffs and is only $\$ 0.03 / \mathrm{W}$ more expensive $(\$ 0.37 / \mathrm{W}$ vs. $\$ 0.40 / \mathrm{W})$ than assembling the module in the United States prior to the $2.5 \mathrm{GW} /$ year cell import threshold. This is partially because U.S. cells are more expensive than Southeast Asian cells. However, once the $2.5 \mathrm{GW} /$ year cell cap has been reached, it becomes more economical to import Southeast Asian modules with mono-facial U.S. cells than to assemble U.S. modules with Southeast Asian mono-facial cells $(\$ 0.40 / \mathrm{W}$ vs. $\$ 0.42 / \mathrm{W})$. Importing a Southeast Asian mono-facial module only costs $\$ 0.46 / \mathrm{W}$, which is equivalent to U.S. module assembly with an entirely Chinese supply chain at the lowest-possible AD/CVD rates, once the $2.5 \mathrm{GW} /$ year cell cap is reached $(\$ 0.46 / \mathrm{W})$. 


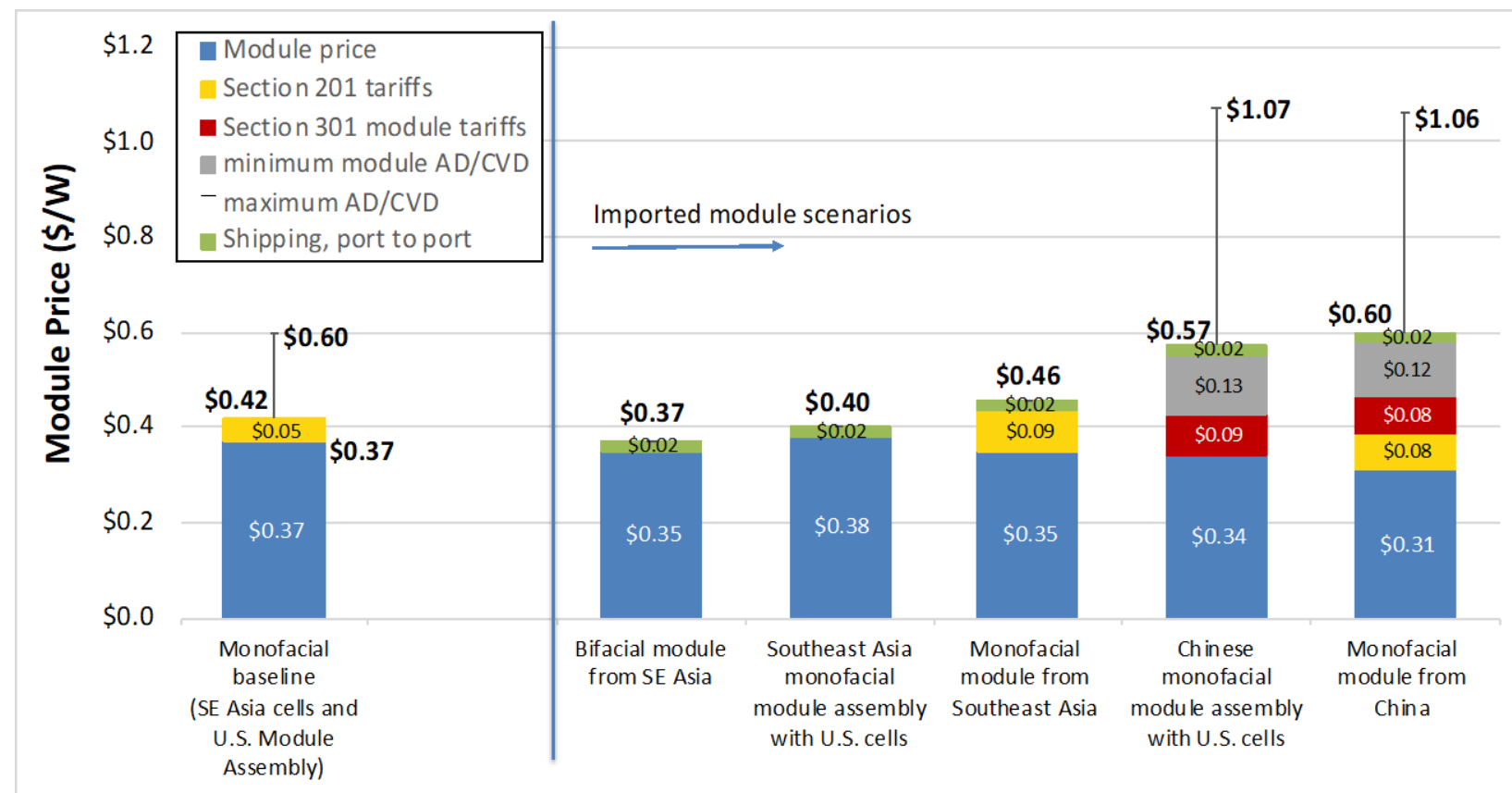

Figure 14. Imported module prices including tariffs on modules imported from China and Southeast Asia, using local or U.S. cell production

The range of $\mathrm{AD} / \mathrm{CVD}$ rates for imported Chinese modules results in a price difference of $\$ 0.50 / \mathrm{W}$. When using the lower value for $\mathrm{AD} / \mathrm{CVD}$ on Chinese modules, importing completed modules from China $(\$ 0.60 / \mathrm{W})$ is equivalent to assembling a module in the United States using all Chinese BoM items imported at the maximum possible tariff rates $(\$ 0.60 / \mathrm{W})$, as defined in Figure 13. However, importing a Chinese module containing U.S. cells under the lower $\mathrm{AD} / \mathrm{CVD}$ module rate does offer an advantage compared to the most expensive baseline U.S. module assembly scenario $(\$ 0.57 / \mathrm{W}$ vs. $\$ 0.60 / \mathrm{W})$.

\subsubsection{U.S. Module Production}

This section covers U.S. module production, considering production with U.S. cells or cells imported either above or below the $2.5 \mathrm{GW} /$ year Section 201 cell import cap. Figure 15 shows U.S. module assembly using BoM items sourced from Chinese suppliers. Again, all cell, module, and BoM pricing data are from NREL (Woodhouse et al. 2019), while each of the tariffs was calculated individually for this report. The leftmost bar represents U.S. module assembly using U.S. cells, which is slightly less expensive than the baseline scenario after the $2.5 \mathrm{GW} /$ year cap has been reached $(\$ 0.45 / \mathrm{W}$ vs. $\$ 0.46 / \mathrm{W})$, as shown in Figure 13. The next two bars represent U.S. module assembly using cells imported from Southeast Asia, which are identical to the baseline scenarios shown in Figure 13, although totals differ slightly due to rounding. These first three bars all have an $\mathrm{AD} / \mathrm{CVD}$ range of $\$ 0.13 / \mathrm{W}$. 


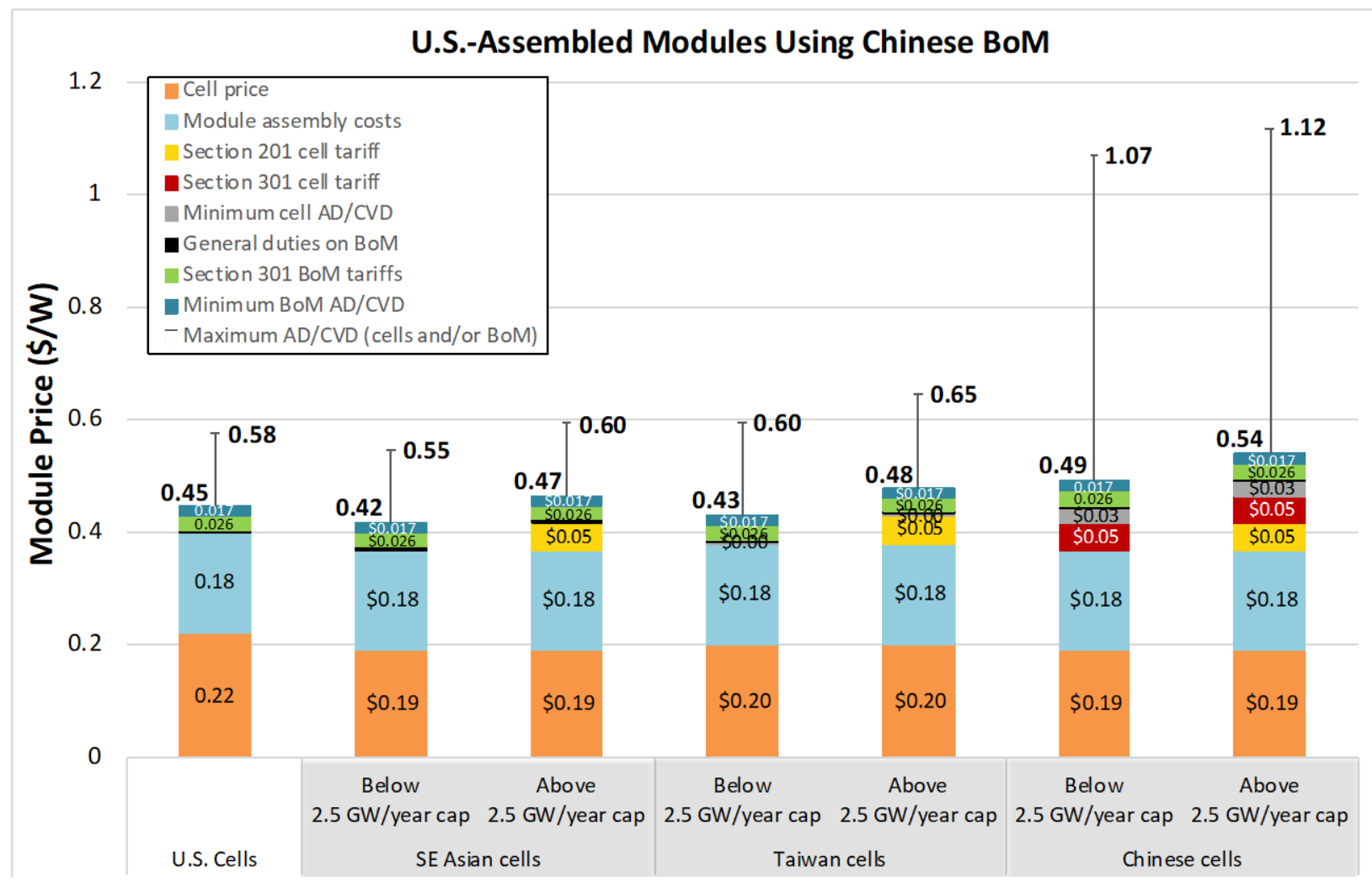

Figure 15. U.S.-assembled module prices as a function of cell origins and Section 201 cell cap (2.5 GW/year) status, using BoM items from Chinese suppliers

The next two bars show U.S. module assembly using cells imported from Taiwan, and the error bars include the high $\mathrm{AD} / \mathrm{CVD}$ rates for both cells and BoM items. Importing cells from Taiwan results in modules at least $\$ 0.06 / \mathrm{W}$ more expensive than the baseline scenarios shown in Figure 13 (with non-Chinese BoM items), and the AD/CVD rates result in a range of $\$ 0.17 / \mathrm{W}$.

Finally, the last pair of bars represents U.S. module assembly using imported Chinese cells, and the error bars for this pair account for the high AD/CVD rates for cells and BoM items, resulting in a range of $\$ 0.58 / \mathrm{W}$. At the lowest-possible $\mathrm{AD} / \mathrm{CVD}$ rates, importing Chinese cells does not represent an improvement over the baseline values shown in Figure 13.

Figure 16 compares modules assembled in the United States using BoM items sourced from nonChinese suppliers. The leftmost bar represents U.S. module assembly using U.S. cells, which is slightly less expensive than the baseline scenario after the $2.5 \mathrm{GW} /$ year cap has been reached $(\$ 0.40 / \mathrm{W}$ vs. $\$ 0.42 / \mathrm{W})$, as shown in Figure 13. The next two bars represent U.S. module assembly using cells imported from Southeast Asia, which are identical to the baseline scenarios shown in Figure 13. 


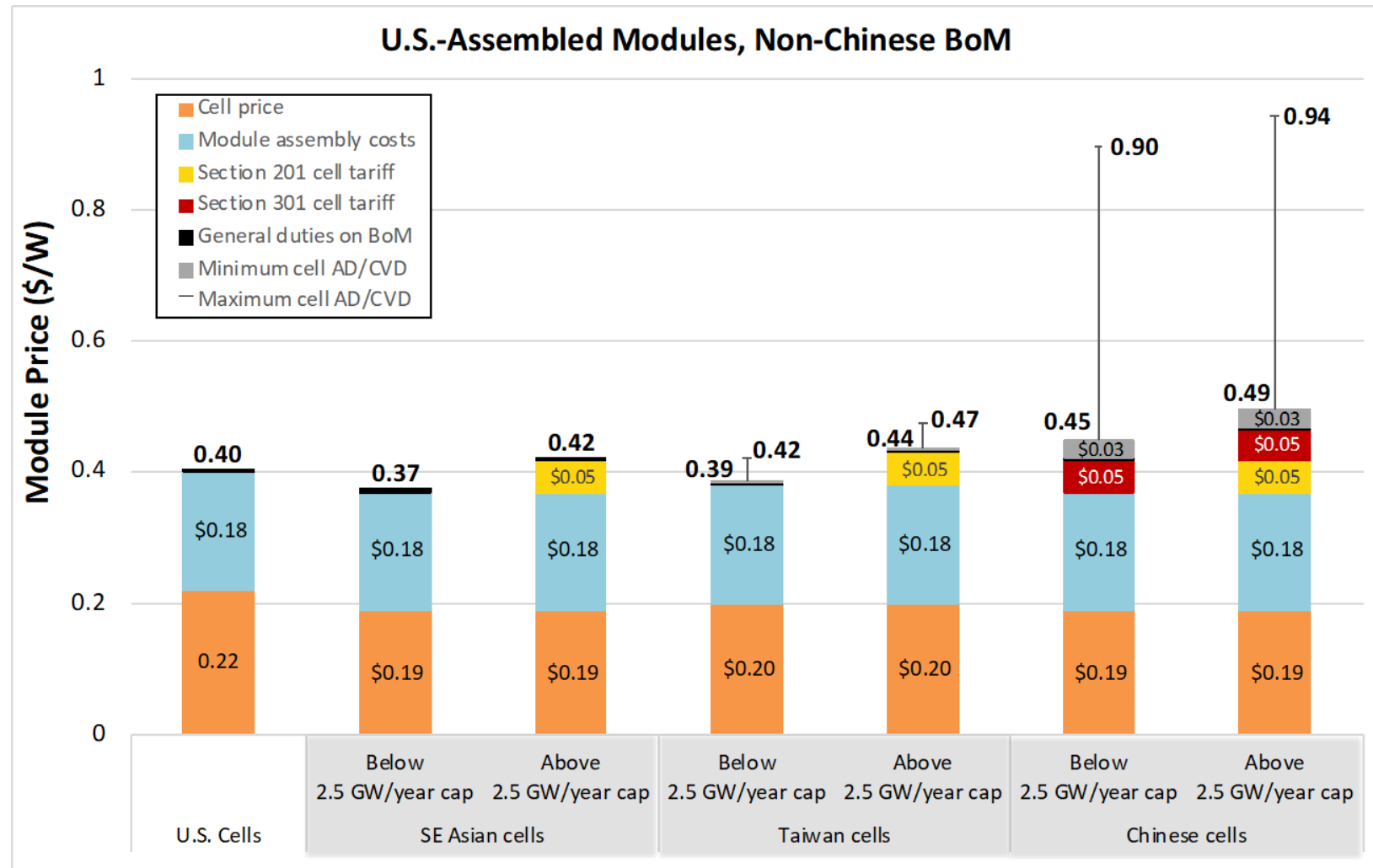

Figure 16. U.S.-assembled module prices as a function of cell origins and Section 201 cell cap (2.5 GW/year) status, using BoM items from non-Chinese suppliers

The next two bars show U.S. module assembly using cells imported from Taiwan, and the error bars include the high AD/CVD rates for cells. Importing cells from Taiwan results in modules at least $\$ 0.02 / \mathrm{W}$ more expensive than the baseline scenarios shown in Figure 13, and the AD/CVD rates result in a range of $\$ 0.03 / \mathrm{W}$.

Finally, the last pair of bars represents U.S. module assembly using imported Chinese cells, and the error bars for this pair account for the high AD/CVD rates for cells, resulting in a range of $\$ 0.45 / \mathrm{W}$. At the lowest-possible AD/CVD rates, importing Chinese cells does not represent an improvement over the baseline values shown in Figure $13(\$ 0.45 / \mathrm{W}$ below $2.5 \mathrm{GW} /$ year and $\$ 0.49 / \mathrm{W}$ above $2.5 \mathrm{GW} /$ year for Chinese cells vs. $\$ 0.37 / \mathrm{W}$ below $2.5 \mathrm{GW} /$ year and $\$ 0.42 / \mathrm{W}$ above $2.5 \mathrm{GW} / \mathrm{year}$ for Southeast Asian cells).

\subsubsection{Section 301, Third List: 10\% Tariffs}

Figure 17 shows the effect of a 10\% rate on the third list of the Section 301 tariffs, which can be compared with the $25 \%$ rate used in Figure 13 . The only two items not included on the third list are encapsulants and backsheets. Summing the Section 301 tariffs when List 3 is at 25\% corresponds to about $\$ 0.026 / \mathrm{W}$, while a List 3 with a $10 \%$ tariff results in total Section 301 tariffs on BoM items of $\$ 0.014 / \mathrm{W}$. Therefore, the difference between the two List 3 rates is approximately $\$ 0.012 / \mathrm{W}$, which is reflected in the difference between final prices in Figure 13 and Figure 17. 


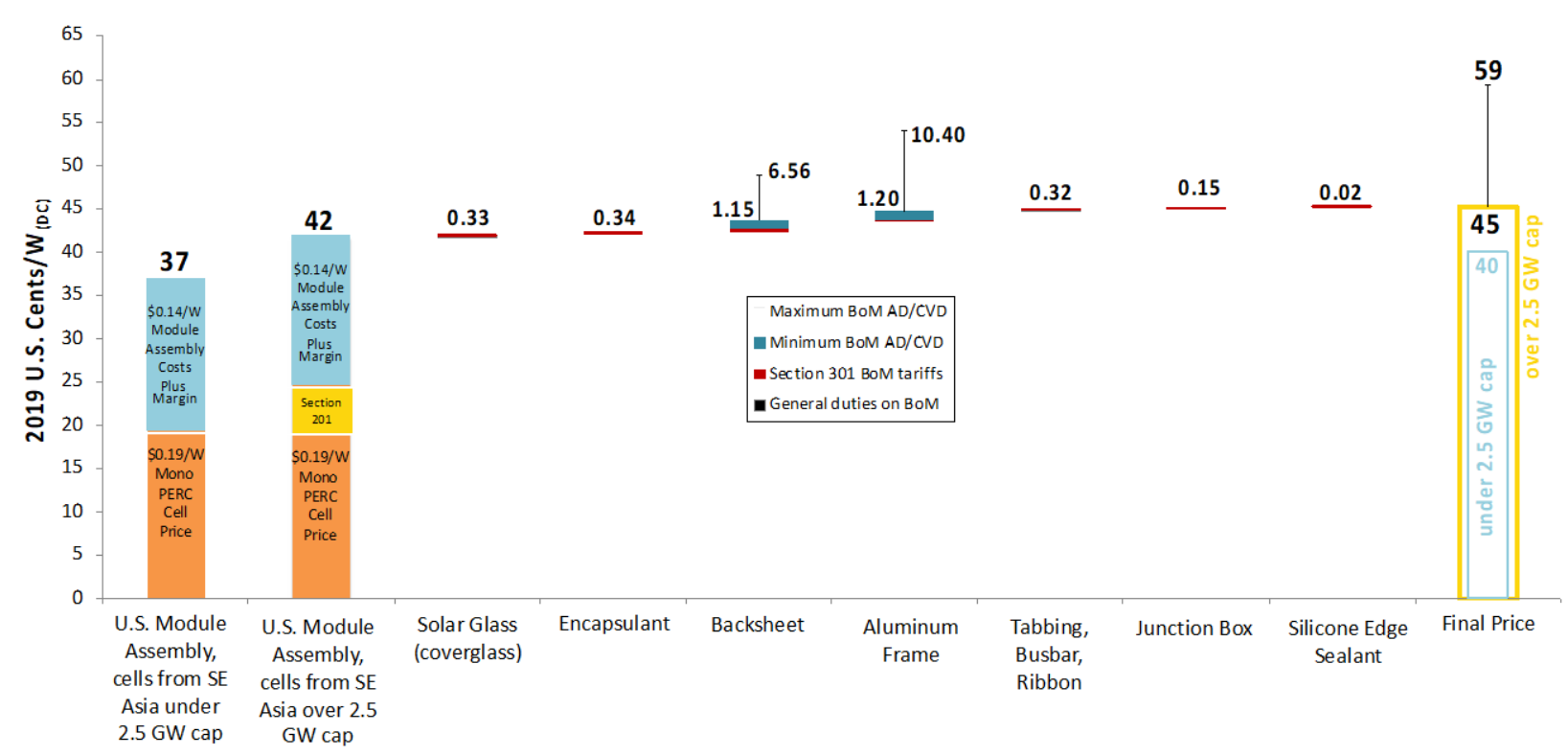

Figure 17. Section 301 tariffs on BoM items when the third list is set to $10 \%$

\subsubsection{Improvements over Baseline Scenarios}

In order to perform a comprehensive evaluation of all the scenarios in this section as they compare to the baseline scenarios detailed in Figure 13 and Figure 17, Table 10 lists which nonbaseline scenarios have module prices that are lower than or equivalent to baseline module prices. Most notably, imported complete module prices are lower than prices in some of the baseline scenarios in a few instances. These include imported bifacial modules from Southeast Asia, which are lower priced than in every other scenario due to the Section 201 bifacial exemption. They also include imported modules from Southeast Asia that contain U.S. cells, which are lower priced than almost every baseline module except for U.S. modules assembled using imported Southeast Asian cells under the $2.5 \mathrm{GW} /$ year cap. Imported complete modules from Southeast Asia that have cells from Southeast Asia (not China or Taiwan) are lower priced than all the baseline modules using Chinese BoM items, except at the lowest AD/CVD rates if the cells are imported below the $2.5 \mathrm{GW} /$ year cap. Finally, importing Chinese modules that contain U.S. cells is less expensive than U.S. assembly of modules using SE Asian cells after the $2.5 \mathrm{GW} /$ year cap has been reached, assuming Chinese BoM items are used at the highest possible $\mathrm{AD} / \mathrm{CVD}$ rates. 
Table 10. Tariff Scenarios with Module Prices Lower than or Equivalent to Baseline Module Prices

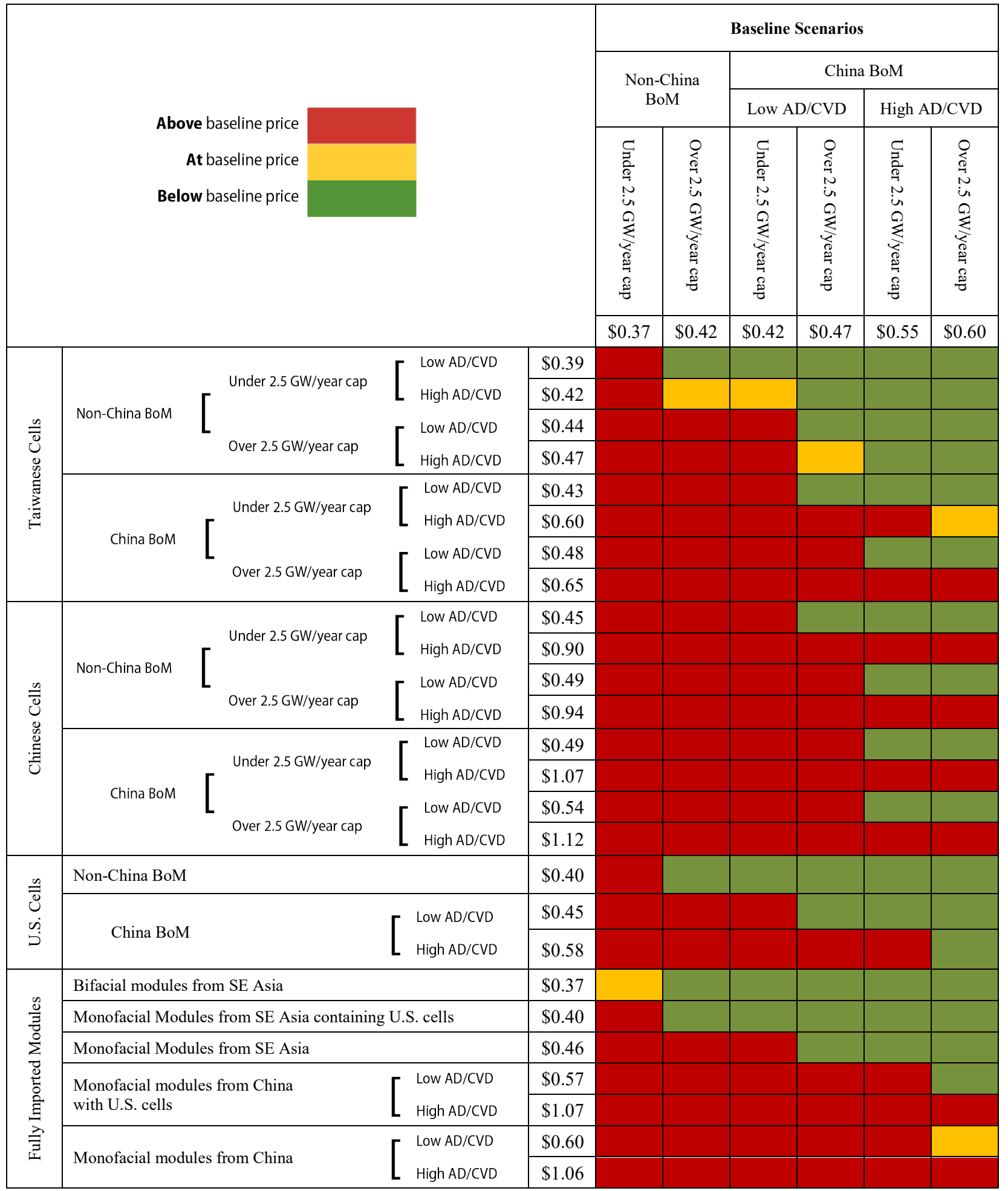

Notably, importing cells from Taiwan appears to result in price-competitive U.S.-assembled modules compared to some baseline scenarios, even though such cells are subject to Section 201 
and $\mathrm{AD} / \mathrm{CVD}$ tariffs. This includes importing cells from Taiwan under the $2.5 \mathrm{GW} / \mathrm{year}$ cap at the lowest-possible $\mathrm{AD} / \mathrm{CVD}$ rate, which are then assembled into modules using non-Chinese BoM items; this scenario is competitive with all baseline scenarios except the first (which imports Southeast Asian cells under the $2.5 \mathrm{GW} /$ year cap and uses non-Chinese BoM items). Importing cells from Taiwan under the $2.5 \mathrm{GW} /$ year cap at the highest $\mathrm{AD} / \mathrm{CVD}$ rate and using non-Chinese BoM items is competitive with all baselines except the first two. Even importing cells from Taiwan over the $2.5 \mathrm{GW} /$ year cap at the high $\mathrm{AD} / \mathrm{CVD}$ rate and using them in modules with non-Chinese BoM items results in lower-priced modules than in the baseline scenarios that rely on Chinese BoM items imported at high $\mathrm{AD} / \mathrm{CVD}$ rates.

\section{Research Gaps}

During the course of this work, the following gaps in research and analysis were identified for which additional effort may be of value.

\section{Expansion Tradeoffs}

The tradeoffs presented when deciding to build U.S. PV manufacturing capacity merit further examination, which could include: 1) comparing the CapEx and incentives amounts to the total tariffs avoided for a given firm, 2) quantifying the cost tradeoffs of greenfield facilities compared to occupying vacant buildings or reworking an existing PV facility, and 3) assessing whether firms tend to rely on used equipment for certain processes and new equipment for othersparticularly in the context of CapEx and labor intensities. Similarly, a comparison between expanding cell capacity versus module capacity could be drawn, to identify the factors that caused firms to abandon their cell expansion plans and generally what factors prevent significant cell capacity from being established in the United States.

\section{Creating Jobs and Value}

This report only focuses on employment for operating the manufacturing facility. Future research could include quantifying employment in the construction industry, tooling manufacturing industry, and so forth, to account for all direct, indirect, and induced employment. Input-output models like IMPLAN could be used to perform this analysis. Other labor considerations include evaluating U.S. labor use for products with labels such as "made in USA" or "assembled in USA" and comparing situations in which the criteria for such a label are more or less rigorous. This could additionally help determine the value-added of applying such a label. More broadly, evaluating the value of cell production versus module assembly and mapping the distribution of facilities for a given firm could enable assessment of the distribution of value for different facility locations and supply chain segments.

\section{BoM Manufacturing}

In order to assess the of validity of assuming U.S. manufacturers can find BoM items from other sources at the same prices as Chinese BoM items, quantifying BoM prices available to U.S. module plants and comparing them to the BoM prices available in China would be necessary. A next step could be to identify what factors would be needed to motivate U.S.-based supply of BoM items (such as scale of demand, or pricing and margins) as well as determining what would 
be needed for U.S. BoM manufacturers to compete with foreign suppliers on speed, price, and quality.

\section{Profit, Capital, and Financing}

Creating a more complete and realistic comparison of module prices by region could be achieved by: 1) comparing profit margins for PV manufacturing sites and firms across different countries, 2) comparing U.S. access to capital versus access in China, South Korea, or countries in Southeast Asia, and 3) comparing financing differences (debt to equity ratio, long-term versus short-term debt) for PV manufacturers and analyzing by region, scale, vertical integration, and so forth.

\section{Other Temporal Analysis}

Analyzing changes in U.S. investments pre- and post-tariffs would complement this assessment of manufacturing capacity before and after the tariffs. Similarly, capacity growth in other markets over the same period could be analyzed to determine if any observations in this report were reflected across the global PV industry, rather than just attributable to factors specific to the United States. Finally, a retrospective analysis of the mechanisms that caused previous U.S. PV manufacturing sites to close could be useful to contrast with the new capacity described in this report.

\section{Broader Tariff Impacts}

Expanding the analysis in this report to assess tariff impacts on upstream and downstream PV industries may be warranted. Primarily, this could include identifying how the tariffs affected imports of PV machinery and equipment, as well as their effects on PV racking prices and the subsequent impacts on PV sales and the racking industry.

\section{Current Market Pricing}

One limitation of the analysis presented in this work is the divergence of the MSP from current market pricing. It may be useful to repeat this analysis using an estimated breakdown of current market pricing rather than a bottom-up cost model of sustainable pricing.

\section{Conclusions}

This report analyzes U.S. PV manufacturing announcements from 2017 through July 2019, presents eight case studies for U.S.-based PV manufacturers that made announcements during this period, and explores the potential impact of tariffs on the competitiveness of U.S. PV module manufacturing. The major findings are summarized below.

\section{U.S. PV Manufacturing Announcements}

From 2017 through July 2019, several manufacturers announced plans to expand U.S. domestic PV production capacity (Table 11). If all planned capacity expansions were successfully implemented, the United States would have a total of $9.6 \mathrm{GW} /$ year of module capacity (including c-Si and thin-film PV) and 1.8 GW/year of c-Si cell capacity. However, as of July 2019, the 
expected capacity total includes $5.6 \mathrm{GW} /$ year of c-Si PV module assembly capacity (including capacity existing before 2017, $0.9 \mathrm{GW} /$ year of module announcements that have been completed, and an expected $3.4 \mathrm{GW} /$ year that have initiated pilot production), $0.5 \mathrm{GW} /$ year of c-Si cell production, and $2.1 \mathrm{GW} /$ year of thin-film module production. This corresponds to a total U.S. PV module capacity of $7.7 \mathrm{GW} /$ year. The U.S. demand for PV installations in the past few years has been approximately $10 \mathrm{GW} /$ year. Although $7.7 \mathrm{GW} /$ year of U.S. PV module production cannot completely supply this level of domestic demand, it would represent a significant increase over annual U.S. PV manufacturing production in the past decade.

Table 11. Historical and Projected U.S. PV Manufacturing Capacity Based on Company Announcements

\begin{tabular}{|c|c|c|c|}
\hline & Historical & $\begin{array}{c}\text { Projection: } \\
\text { best-case scenario }\end{array}$ & $\begin{array}{c}\text { Projection: } \\
\text { expected outcome }\end{array}$ \\
\hline & $\begin{array}{c}\text { Existing prior to } \\
\text { announcements } \\
\text { (GW/year) }\end{array}$ & $\begin{array}{c}\text { Includes all } \\
\text { announcements and } \\
\text { existing capacity } \\
\text { (GW/year) }\end{array}$ & $\begin{array}{l}\text { Based on existing } \\
\text { and pilot production } \\
\text { as of July } 2019 \\
\text { (GW/year) }\end{array}$ \\
\hline U.S. c-Si Cell Capacity & 0.2 & 1.8 & 0.5 \\
\hline U.S. c-Si Module Capacity & 1.3 & 7.5 & 5.6 \\
\hline U.S. Thin-Film Module Capacity & 0.9 & 2.1 & 2.1 \\
\hline Total Module Capacity & 2.2 & 9.6 & 7.7 \\
\hline
\end{tabular}

The largest fraction of planned capacity expansions was from companies headquartered in the United States (50\%), while the second largest was from South Korean companies (29\%).

Companies with no previous physical U.S. manufacturing, R\&D, or installer facilities were most common ( $45 \%$ by capacity), followed closely by companies that already had U.S. PV manufacturing facilities (41\%). Mono-PERC modules were the most common target product (41\%). Greenfield facilities accounted for the largest share of capacity (39\%), which included only two facilities. The second-largest share of capacity (34\%) used existing vacant buildings in the interest of time, to gain the largest possible benefits from the Section 201 tariffs.

This report also analyzes statistics related to labor, CapEx, and incentive intensities. Both the number of employees and the CapEx per GW/year of planned module capacity appear to correlate negatively with plant size. These intensities range from 300 to 1,500 employees per GW/year and \$20 million to \$330 million of CapEx per GW/year (for some sites, CapEx intensities also apply to cell production at the same location). The value of local incentives offered to expanding companies corresponded to $\$ 1-\$ 55$ million of incentives per GW/year of module capacity, $\$ 0.06-\$ 0.20$ of incentives per dollar of CapEx, and $\$ 8,000-\$ 50,000$ of incentives per employee.

\section{U.S. PV Manufacturing Case Studies}

In the first half of 2019, we interviewed representatives at eight of the firms that announced plans for expanded U.S. production since early 2017. The firms include Auxin Solar, which had an $8 \%$ share of U.S. module production capacity in 2017, First Solar (48\%), Hanwha Q Cells 
(0\%), JinkoSolar (0\%), LG (0\%), Silfab (9\%), Solaria (3\%), and SunPower (5\%). The proposed expansions of these eight firms represent $4.4 \mathrm{GW}$, which is $70 \%$ of all proposed expansions. The firms were selected to cover a range of sizes, locations, ownership structures, and technologies. The case studies highlight the importance of the following five factors in influencing firms' decisions to expand their U.S. PV production capacity:

- Proximity to demand. For most firms, a major motivation to locate manufacturing in the United States was the significant domestic U.S. demand for their technology through existing supply chains or specific supply contracts. Multiple firms also noted that demand for made- or assembled-in-USA products, including supply contracts with minimum domestic content requirements, was an important driver.

- Ability to move quickly. Most firms mentioned the desire to move quickly to maximize the benefits of the Section 201 tariffs. This included moving into existing structures, relocating existing equipment from other manufacturing sites, or purchasing entire existing solar facilities while upgrading the equipment and retaining the employees. Similarly, some firms also mentioned the ease and rapidity of facility acquisition and permitting as a deciding factor when selecting a locality. Some firms cited the time and investment necessary for cell-fabrication facilities as a major reason for the lack of much existing or planned U.S. cell capacity.

- Tariffs and other incentives. Most firms seemed supportive of the Section 201 tariffs, although they commonly expressed the belief that the cell import cap should be higher than $2.5 \mathrm{GW} /$ year. Most firms also said they located new capacity in existing facilities or buildings to reduce lead time and capitalize on the Section 201 tariffs as soon as possible. However, most firms stated that the Section $301^{12}$ tariffs offset at least some - if not all — of the U.S. manufacturing competitiveness provided by the Section 201 tariffs (both sets of tariffs are described fully in Section 2 of this report). Because U.S. supply chains do not exist for most PV module components, or do not exist at a scale to supply the PV module industry, importing components subject to Section 301 tariffs was difficult to avoid. Furthermore, uncertainty regarding the scheduled increase of the Section 301 tariff rate hindered the sourcing of components affected by the tariffs; supplier quotes include tariff costs, so suppliers required an extra payment in case of a tariff increase. Most firms mentioned that the 2018 decrease in the U.S. corporate tax rate made a stronger financial case for adding U.S. manufacturing, although most also said they were already exploring the option before the tax rate reduction was anticipated. The majority of firms indicated that local incentives (such as tax benefits or labor availability) were considered in their selection of a manufacturing site, but many indicated that similar local financial incentives were available at all locations under consideration.

- Access to capital. Several firms cited access to capital as a primary challenge when expanding U.S. manufacturing. Larger firms often financed their expansions internally, whereas smaller firms had more challenges accessing capital.

- Competition with scale. Some smaller firms expressed concern that larger firms may not need their U.S. facilities to be profitable, which would limit the smaller firms'

\footnotetext{
${ }^{12}$ These statements were made by firms in March and April of 2019, when the Section 301 tariffs were 25\% for Lists 1 and 2, and $10 \%$ for List 3. List 4 did not exist yet. Rates have changed since then and are partially documented in Section 2.
} 
ability to compete and influenced their decision to expand in the United States. Similarly, many firms communicated that competing with or avoiding the need to import Asian PV components (e.g., cells, modules, cover glass) is challenging owing to the larger scale of Asian manufacturers and their lower reliance on profit margins.

\section{PV Tariff Analysis}

Several U.S. tariffs affect the economics of PV cells, modules, and BoM materials, some of which are applicable to a long list of countries and others applicable only to China or Taiwan. We analyze how the tariffs (described in Section 2) interact to affect the prices of c-Si modules sourced under various assumptions about domestic and imported components and assembly. We estimate module prices using a bottom-up cost model under a range of baseline scenarios featuring U.S.-assembled modules with Southeast Asian cells (not from China or Taiwan). The cost model assumes a gross margin of $28 \%$ and operating margin of $15 \%$. We assume the BoM items can be sourced from countries other than China at the same price as Chinese BoM, but this may not be a realistic assumption for all items. If all BoM items are sourced from countries other than China, baseline module prices are $\$ 0.37 / \mathrm{W}$ (below the $2.5 \mathrm{GW} /$ year cell cap for Section 201 ) to $\$ 0.42 / \mathrm{W}$ (above the $2.5 \mathrm{GW} /$ year cell cap), assuming general duties are negligible. If all BoM items are sourced from China, the module price in the baseline U.S.-assembly scenarios can reach up to $\$ 0.60 / \mathrm{W}$.

Imported module prices are lower than or within the range of the U.S.-assembled baseline prices under some conditions. Importing bifacial modules from Southeast Asia is the lowest-priced alternative, at $\$ 0.37 / \mathrm{W}$, because bifacial modules are excluded from the Section 201 tariffs and importing finished modules avoids the Section 301 tariffs. Importing Southeast Asian modules that have Southeast Asian cells yields a price of $\$ 0.46 / \mathrm{W}$, and importing Chinese modules that have U.S. cells yields a price of $\$ 0.57 / \mathrm{W}$.

Module prices for select scenarios in mid-2019 are shown in Figure 18; more scenarios are detailed in Section 5. All modules are mono-facial monocrystalline PERC modules. The bar on the left represents imports from Southeast Asia, and the bars on the right side of the figure show four scenarios for U.S. module assembly relying on imported cells. The first two U.S. module assembly scenarios assume that cells are imported under the $2.5 \mathrm{GW} /$ year cap. The first scenario assumes no BoM items are sourced from China, while the second assumes all BoM items are sourced from China. The second pair of scenarios assumes that cells are imported above the 2.5 $\mathrm{GW} /$ year cap. The third bar in this section assumes no BoM items are sourced from China, while the fourth assumes all BoM items are sourced from China. These results suggest that U.S. tariff policy in 2019 may encourage U.S. assembly of mono-facial c-Si modules if the $2.5 \mathrm{GW} /$ year cell import cap is not reached and Chinese BoM imports are negligible. However, some imported module options may offer the lowest prices if the $2.5 \mathrm{GW} /$ year cell import cap is reached and/or U.S. module manufacturers must rely on significant Chinese BoM content. 


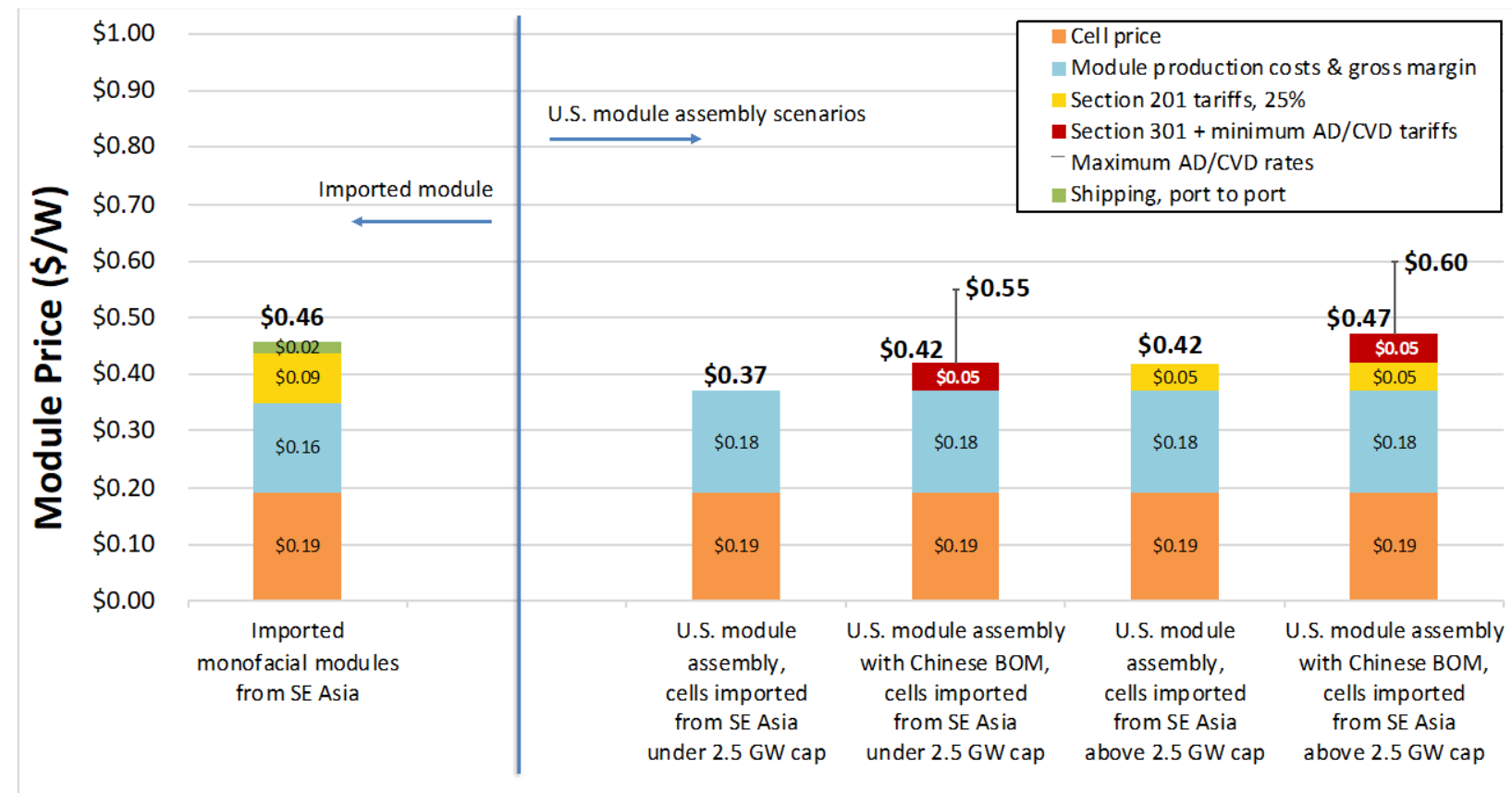

Figure 18. PERC module prices under various manufacturing scenarios and tariff conditions, mid2019

Our research indicates the $2.5 \mathrm{GW} /$ year cell cap may be exceeded in 2019 or following years if U.S. capacity utilization rates are high, and that U.S. module manufacturers likely will need to use at least some Chinese BoM content, which helped us define the scenarios selected for analysis shown in Figure 18. If all U.S. module plants that were in pilot production as of July 2019 reach full capacity, up to $5.6 \mathrm{GW} /$ year of cells would need to be imported each yeartherefore, up to about $3 \mathrm{GW} /$ year of cells would be subject to the existing Section 201 cell tariffs. If all U.S. plans for c-Si module capacity announced from 2017 through July 2019 are fully realized, the need for imported cells would increase to $5.7 \mathrm{GW} /$ year, and thus up to $3.2 \mathrm{GW} /$ year of cells might become subject to the existing Section 201 cell tariffs. With regard to Chinese BoM content, U.S. module manufacturers have stated that U.S. supply chains do not exist (or do not exist at a sufficient scale) for most BoM items, which makes them at least partially reliant on Chinese BoM items and thus subject to Section 301 tariffs. 


\section{References}

Alabama Office of the Governor. 2018. Governor Ivey Announces LG Electronics to Open Alabama Solar Panel Plant, Creating 160 Jobs. https:/governor.alabama.gov/pressreleases/governor-ivey-announces-lg-electronics-to-open-alabama-solar-panel-plantcreating-160-jobs/.

Basch, Mark. 2018. JinkoSolar executive: Jacksonville plant will be 'a showcase'. Jacksonville Daily Record.

Beetz, Becky. 2018. Silfab unveils US manufacturing site with $\$ 40$ million investment in Itek Energy. PV-magazine.org.

BNEF. 2018. Bloomberg New Energy Finance. New York.

Brune Mathis, Karen. 2018a. JinkoSolar Launches Pilot Production At Jacksonville Plant. WJCT Public Media. Accessed May 24, 2019.

Brune Mathis, Karen. 2018b. JinkoSolar plans \$50 million plant at Cecil Commerce Center with 200 jobs; will open HQ in Jacksonville. Jacksonville Daily Record. Accessed May 24, 2019.

Carlson, Kara. 2017. "Washington solar incentives bill has industry seeing sunny days." Last Modified April 19, 2019. https://governorswindenergycoalition.org/washington-solarincentives-bill-has-industry-seeing-sunny-days/.

Chen, Zhisong, and Shong-Iee Ivan Su. 2019. "International competition and trade conflict in a dual photovoltaic supply chain system." Renewable Energy. doi: https://doi.org/10.1016/j.renene.2019.11.085.

Colville, Finlay. 2019. PV industry benchmarks for module technology and bankability are driven by JinkoSolar. PVTech.

Connor, Gregory. 2019. "Personal Communication with U.S. Customs and Border Protection Chief of the Electronics, Machinery, Automotive, and International Nomenclature Branch." April 11, 2019.

Eckhouse, Brian, and Joe Deaux. 2019. Unintended Fallout of Trump Steel Duty: Solar Buying Abroad. Bloomberg.

Feldman, David J, and Robert M Margolis. 2019. Q1/Q2 2019 Solar Industry Update. https://www.nrel.gov/docs/fy19osti/74585.pdf: National Renewable Energy Lab.(NREL), Golden, CO (United States).

First Solar. 2019a. First Solar 2018 Annual Report. https://investor.firstsolar.com/financials/annual-reports/default.aspx.

First Solar. 2019b. First Solar Corporate Factsheet | 2019. http://www.firstsolar.com//media/First-Solar/Documents/Corporate-Collaterals/FS_Corporate_Factsheet.ashx.

First Solar. 2019c. First Solar Q1 '19 Earnings Call Presentation. https://investor.firstsolar.com/financials/quarterly-results/default.aspx.

Flessner, Dave. 2018. Korean firm plans to hire 500 workers for new $\$ 150$ million solar module plant in Dalton. Times Free Press. Accessed April 18, 2019.

Foehringer Merchant, Emma. 2018a. Heliene Will Become First Foreign Solar Company to Produce Modules After Trump Tariffs. GreenTech Media.

Foehringer Merchant, Emma. 2018b. Sunpreme Plans Texas Cell and Module Facility in 2019. GreenTech Media.

Foehringer Merchant, Emma. 2019. The Status of US Solar Manufacturing, One Year After Tariffs. GreenTech Media. Accessed April 21, 2019. 
Goldman Sachs. 2019. Global Markets Institute. New York: https://www.goldmansachs.com/what-we-do/research.html.

GreenBrilliance USA. 2018. GreenBrilliance USA announces PV manufacturing in the United States. https://pv-magazine-usa.com/press-releases/greenbrilliance-usa-announces-pvmanufacturing-in-the-united-states/.

Gregorio, Dave. 2018. China's Jinko to produce solar panels in Florida by fourth quarter despite tariffs. Reuters. Accessed May 24, 2019.

Groom, Nichola. 2018. Trump's latest tariffs undercut his first trade salvo in solar. Reuters. Accessed April 19, 2019.

GTM Research, and SEIA. 2016. U.S. Solar Market Insight Report 2015 Year in Review. https://www.seia.org/research-resources/solar-market-insight-2015-q4.

GTM Research, and SEIA. 2017. U.S. Solar Market Insight -- Full Report -- 2016 Year in Review. https://www.seia.org/research-resources/solar-market-insight-report-2016-yearreview.

GTM Research, and SEIA. 2018. U.S. Solar Market Insight 2017 Year in Review. https://www.seia.org/research-resources/solar-market-insight-report-2017-year-review.

Hamann, Emily. 2018. Canadian company invests in Bellingham solar panel manufacturer Itek. The Bellingham Business Journal.

Hughes, Llewelyn, and Jonas Meckling. 2017. "The politics of renewable energy trade: The USChina solar dispute." Energy Policy 105:256-262. doi: https://doi.org/10.1016/j.enpol.2017.02.044.

Hughlett, Mike. 2019. Canadian company sets up shop on Iron Range to make solar panels. StarTribune.

Industrial Development Authority of Russell County Virginia. 2019. "ST. PAUL - FORMER BUSH FURNITURE BUILDING." accessed May 27, 2019. http://russellcountyida.org/buildings-sites/available-buildings-sites/st-paul-former-bushfurniture-building-industrial-manufacturing/.

Jossi, Frank. 2018. Canadian company reboots northern Minnesota solar panel factory. https://energynews.us/2018/07/23/midwest/canadian-company-reboots-northernminnesota-solar-panel-factory/.

Lambert, Fred. 2017. Tesla starts solar cell production at Gigafactory 2 in Buffalo, raises annual capacity goal to $2 \mathrm{GW}$. https://electrek.co/2017/08/31/tesla-solar-cell-productiongigafactory-2-buffalo-solar-roof/.

Limpf, Larry. 2018. State approves tax credit for First Solar The Press. Accessed April 18, 2019.

McClellan Park. 2017. "Solar module factory moving forward at McClellan Business Park." accessed August 12, 2019. http://www.mcclellanpark.com/News/Blog/PostId/52/solarmodule-factory-moving-forward-at-mcclellan-business-park.

Nevada Governor's Office of Economic Development. 2017. "Sunpreme, Inc.", accessed August 9, 2019. http://www.diversifynevada.com/wpcontent/uploads/2018/12/5 E. Sunpreme Inc. - Board Packet.pdf.

Nguyen, Ly, and Henry W. Kinnucan. 2019. "The US solar panel anti-dumping duties versus uniform tariff." Energy Policy 127:523-532. doi: https://doi.org/10.1016/j.enpol.2018.11.048.

Nsehe, Mfonobong. 2019. Why The Solar Energy Market Will Thrive In Africa And Globally Lou Kraft, SolSuntech CEO. Forbes.

Oliver, Charles. 2019. Hanwha plant up to more than 750 employees. Daily Citizen-News. 
Osborne, Mark. 2017a. Hanwha Q CELLS garners \$317.1 million module supply deal with Florida utility. PVTech. Accessed April 18, 2019.

Osborne, Mark. 2017b. Seraphim Solar USA ramps module capacity and gains vendor approval from residential finance firms. https://www.pv-tech.org/news/seraphim-solar-usa-rampsmodule-capacity-and-gains-vendor-approval-from-res.

Owens, Baker. 2019. Kemp Announces \$150 Million Solar Investment in Southwest Georgia. Southern Political Report. Accessed April 18, 2019.

Parnell, John. 2018. Hanwha Q CELLS to build new US factory in excess of 1.6GW. PVTech.

Pickerel, Kelly. 2017a. CSUN now taking orders for c-Si solar modules out of new California factory. Solar Power World. Accessed May 24, 2019.

Pickerel, Kelly. 2017b. Q\&A with California-based solar panel manufacturer Auxin Solar. Solar Power World. Accessed March 30, 2019.

Pickerel, Kelly. 2018a. First Solar will build second, 1.2-GW capacity module manufacturing facility in Ohio. https://www.solarpowerworldonline.com/2018/04/first-solar-will-buildsecond-1-2-gw-capacity-module-manufacturing-facility-in-ohio/.

Pickerel, Kelly. 2018b. How to start a solar panel manufacturing facility in the United States. Solar Power World. Accessed March 30, 2019.

Pickerel, Kelly. 2018c. SunPower to acquire 100\% of SolarWorld Americas. Solar Power World. Accessed April 20, 2019.

Pickerel, Kelly. 2018d. Two brand-new manufacturing names want a piece of the Made in USA solar panel market. https://www.solarpowerworldonline.com/2018/11/two-brand-newmanufacturing-names-want-a-piece-of-the-made-in-usa-solar-panel-market/.

Pickerel, Kelly. 2018e. What's happening with U.S. solar after four months of panel tariffs. https://www.solarpowerworldonline.com/2018/06/whats-happening-with-u-s-solar-afterfour-months-of-panel-tariffs/.

Pickerel, Kelly. 2019a. New U.S. solar panel manufacturing activity happening in 2019. Solar Power World. Accessed April 18, 2019.

Pickerel, Kelly. 2019b. Three things SPW learned after touring JinkoSolar's Florida panel facility. Solar Power World.

Pyper, Julia. 2018. LG to Build New 500MW Solar Module Manufacturing Plant in Alabama. GreenTech Media. Accessed April 18, 2019.

Robinson, David, and Tom Precious. 2017. The $\$ 750$ million question: When will SolarCity open? The Buffalo News. Accessed May 27, 2019.

Rogers, Debbie. 2018. First Solar to build new facility in Lake Twp., create 500 jobs. Sentinel Tribune.

Rogoway, Mike. 2018. SunPower says tariff exemption saved Hillsboro deal. The Oregonian. Accessed April 20, 2019.

Rogoway, Mike. 2019. SunPower puts Hillsboro factory up for sale but says it will keep operating. The Oregonian. Accessed May 22, 2019.

Rojo Martín, José. 2019. WTO ruling paves way for Chinese retaliation to US over solar duties. PV-tech.org. Accessed October 15, 2019.

Roselund, Christian. 2018a. JinkoSolar reveals details of Jacksonville factory in filing. $P V$ Magazine. Accessed May 24, 2019.

Roselund, Christian. 2018b. Mission Solar to double solar module manufacturing. PV Magazine. Accessed May 24, 2019. 
Roselund, Christian. 2018c. Solaria raises \$23 million, will triple manufacturing capacities. https://pv-magazine-usa.com/2018/01/11/solaria-raises-23-million-will-expandmanufacturing-capacities/.

Roselund, Christian. 2018d. SunPower retools former SolarWorld factory for P-Series. PV Magazine. Accessed April 20, 2019.

Roselund, Christian. 2019. Silfab says it will bring metal wrap through solar to the United States. PV Magazine. Accessed April 19, 2019.

Sandor, Debra, Sadie Fulton, Jill Engel-Cox, Corey Peck, and Steve Peterson. 2018. "System Dynamics of Polysilicon for Solar Photovoltaics: A Framework for Investigating the Energy Security of Renewable Energy Supply Chains." Sustainability 10 (1):160. doi: https://doi.org/10.3390/su10010160.

Silfab Solar. 2018a. PetersenDean Partners with Silfab Solar USA on high efficiency modules. http://www.silfabsolar.com/petersen-dean-partners-with-silfab-solar-usa-on-highefficiency-modules/.

Silfab Solar. 2018b. Titan Solar Power Locks in Silfab Solar for High Efficiency Modules http://www.silfabsolar.com/titan-solar-power-locks-in-silfab-solar-for-highefficiency-modules/.

Smith, Brittany L., and Robert Margolis. 2019. Expanding the Photovoltaic Supply Chain in the U.S.: Opportunities and Challenges. https://www.nrel.gov/docs/fy19osti/73363.pdf: National Renewable Energy Laboratory.

Solaria Corporation. 2019. Solaria Doubles Global Production Capacity. https://static1.squarespace.com/static/568f7df70e4c112f75e6c82b/t/5c6c2f619140b72e1a 18bd92/1550593891470/2.19+FINAL+Solaria+Shinsung.pdf.

SolSuntech. 2018. The U.S. Registered SolSuntech is Creating a Revolution in the Solar Industry by Introducing the Most Efficient Solar Panel on the Global Market.

https://www.accesswire.com/525594/The-US-Registered-SolSuntech-is-Creating-aRevolution-in-the-Solar-Industry-by-Introducing-the-Most-Efficient-Solar-Panel-on-theGlobal-Market.

SPV Market Research. 2018. Photovoltaic Manufacturer Capacity, Shipments, Price \& Revenues 2017/2018. http://www.spvmarketresearch.com/.

SPV Market Research. 2019. Photovoltaic Manufacturer Capacity, Shipments, Price \& Revenues 2018/2019. http://www.spvmarketresearch.com/.

Strevel, Nicholas. 2017. "'THE OPTIMAL PV MODULE SIZE"." accessed April 18, 2019. http://www.firstsolar.com/-/media/First-Solar/Technical-Documents/Series-6Datasheets/Series-6-Optimal-Module-Size-Factsheet.ashx.

Stromsta, Karl-Erik. 2016. SunPower confirms 500MW win in Mexican tender. https://www.rechargenews.com/solar/867429/sunpower-confirms-500mw-win-inmexican-tender.

Sun, Xiaojing. 2016. "The role of policy and markets in the development of the solar photovoltaic industry: Evidence from China." Georgia Institute of Technology.

SunPower Corporation. 2018a. Annual Report 2017. http://www.annualreports.com/HostedData/AnnualReports/PDF/NASDAQ SPWR_2017 .pdf.

SunPower Corporation. 2018b. SunPower Begins A New Chapter in American Solar Manufacturing. https://newsroom.sunpower.com/2018-10-01-SunPower-Begins-A-NewChapter-in-American-Solar-Manufacturing. 
Sylvia, Tim. 2019. SunPower officially producing P-Series at former SolarWorld factory in Oregon. PV Magazine. Accessed April 21, 2019.

Total S.A. 2012. Total and SunPower Commission a New Solar Panel Manufacturing Plant. https://www.total.com/en/media/news/press-releases/energie-solaire-total-et-sunpowerdemarrent-une-nouvelle-usine-de-panneaux-solaires-en-france.

Tsanova, Tsvetomira. 2019. Panasonic selling Buffalo PV cells to client in the Philippines Renewables Now. Accessed June 1, 2019.

U.S. Customs and Border Protection. 2009. H027707: Request for Internal Advice; Subheading 9802.00.50, HTSUS; NAFTA; Marking. https://rulings.cbp.gov/ruling/H027707.

U.S. Customs and Border Protection. 2010. N115543: The tariff classification of ethylene vinyl acetate film from China.

U.S. Customs and Border Protection. 2018a. N301481: The tariff classification of extruded anodized aluminum solar panel frames from China. https://rulings.cbp.gov/ruling/N301481.

U.S. Customs and Border Protection. 2018b. QB 18-111 2018 Solar Cell/Modules. https://www.cbp.gov/trade/quota/bulletin/qb-18-111-2018-solar-cellmodules.

U.S. Customs and Border Protection. 2018c. "Section 201 Trade Remedy on Solar Cells and Panels, and Washing Machines and Parts." accessed April 24, 2019.

U.S. Customs and Border Protection. 2018d. Section 232 Tariffs on Aluminum and Steel. https://www.cbp.gov/trade/programs-administration/entry-summary/232-tariffsaluminum-and-steel.

U.S. Customs and Border Protection. 2018e. Section 301 Trade Remedies to be Assessed on Certain Products from China. https://www.cbp.gov/trade/programs-administration/entrysummary/section-301-trade-remedies.

U.S. Department of Commerce. 2015. Certain Crystalline Silicon Photovoltaic Products from Taiwan: Antidumping Duty Order. https://www.gpo.gov/fdsys/pkg/FR-2015-0218/html/2015-03179.htm.

U.S. Department of Commerce. 2016. Aluminum Extrusions From the People's Republic of China: Final Results of Expedited First Sunset Review of the Antidumping Duty Order https://enforcement.trade.gov/frn/summary/prc/2016-18649.txt.

U.S. Energy Information Administration. 2018. Annual Solar Photovoltaic Module Shipments Report. https://www.eia.gov/renewable/annual/solar_photo/.

U.S. International Trade Administration. 2011a. Aluminum Extrusions from the People's Republic of China: Antidumping Duty Order. https://www.federalregister.gov/documents/2011/05/26/2011-13086/aluminumextrusions-from-the-peoples-republic-of-china-antidumping-duty-order.

U.S. International Trade Administration. 2011b. Aluminum Extrusions From the People's Republic of China: Countervailing Duty Order. https://www.federalregister.gov/documents/2011/05/26/2011-13103/aluminumextrusions-from-the-peoples-republic-of-china-countervailing-duty-order.

U.S. International Trade Administration. 2012a. Crystalline Silicon Photovoltaic Cells, Whether or Not Assembled Into Modules, From the People's Republic of China: Amended Final Determination of Sales at Less Than Fair Value, and Antidumping Duty Order. In 201229668, edited by U.S. International Trade Administration.

https://www.federalregister.gov/documents/2012/12/07/2012-29668/crystalline-siliconphotovoltaic-cells-whether-or-not-assembled-into-modules-from-the-peoples. 
U.S. International Trade Administration. 2012b. Crystalline Silicon Photovoltaic Cells, Whether or Not Assembled Into Modules, From the People's Republic of China: Countervailing Duty Order. In 2012-29669, edited by U.S. International Trade Administration. https://www.federalregister.gov/documents/2012/12/07/2012-29669/crystalline-siliconphotovoltaic-cells-whether-or-not-assembled-into-modules-from-the-peoples.

U.S. International Trade Administration. 2015a. Certain Crystalline Silicon Photovoltaic Products From the People's Republic of China: Antidumping Duty Order; and Amended Final Affirmative Countervailing Duty Determination and Countervailing Duty Order. In 2015-03183, edited by U.S. International Trade Administration. https:/www.federalregister.gov/documents/2015/02/18/2015-03183/certain-crystallinesilicon-photovoltaic-products-from-the-peoples-republic-of-china-antidumping.

U.S. International Trade Administration. 2015b. Crystalline Silicon Photovoltaic Cells, Whether or Not Assembled Into Modules, From the People's Republic of China: Final Results of Antidumping Duty Administrative Review and Final Determination of No Shipments; 2012-2013. In 2015-17238, edited by U.S. International Trade Administration. https://www.federalregister.gov/documents/2015/07/14/2015-17238/crystalline-siliconphotovoltaic-cells-whether-or-not-assembled-into-modules-from-the-peoples\#citation-47p41002.

U.S. International Trade Administration. 2015c. Crystalline Silicon Photovoltaic Cells, Whether or Not Assembled Into Modules, From the People's Republic of China: Final Results of Countervailing Duty Administrative Review; 2012. In 2015-17241, edited by U.S. International Trade Administration. https://www.federalregister.gov/documents/2015/07/14/2015-17241/crystalline-siliconphotovoltaic-cells-whether-or-not-assembled-into-modules-from-the-peoples.

U.S. International Trade Administration. 2016a. Crystalline Silicon Photovoltaic Cells, Whether or Not Assembled Into Modules, From the People's Republic of China: Final Results of Antidumping Duty Administrative Review and Final Determination of No Shipments; 2013-2014. In 2016-14532, edited by U.S. International Trade Administration. https://www.federalregister.gov/documents/2016/06/20/2016-14532/crystalline-siliconphotovoltaic-cells-whether-or-not-assembled-into-modules-from-the-peoples: The Office of the U.S. Federal Register.

U.S. International Trade Administration. 2016b. Crystalline Silicon Photovoltaic Cells, Whether or Not Assembled Into Modules, From the People's Republic of China: Final Results of Countervailing Duty Administrative Review; 2013. In 2016-17064, edited by U.S. International Trade Administration. https://www.federalregister.gov/documents/2016/07/19/2016-17064/crystalline-siliconphotovoltaic-cells-whether-or-not-assembled-into-modules-from-the-peoples: The Office of the U.S. Federal Register.

U.S. International Trade Administration. 2017a. Certain Crystalline Silicon Photovoltaic Products From Taiwan: Final Results of Antidumping Duty Administrative Review; 2014-2016. In 2017-14281, edited by U.S. International Trade Administration. https://www.federalregister.gov/documents/2017/07/07/2017-14281/certain-crystallinesilicon-photovoltaic-products-from-taiwan-final-results-of-antidumping-duty: The Office of the U.S. Federal Register.

U.S. International Trade Administration. 2017b. Certain Crystalline Silicon Photovoltaic Products From the People's Republic of China: Final Results of Antidumping Duty 
Administrative Review and Final Determination of No Shipments; 2014-2016. In 201714611, edited by U.S. International Trade Administration.

https://www.federalregister.gov/documents/2017/07/12/2017-14611/certain-crystallinesilicon-photovoltaic-products-from-the-peoples-republic-of-china-final-results: The Office of the U.S. Federal Register.

U.S. International Trade Administration. 2017c. Certain Crystalline Silicon Photovoltaic Products From the People's Republic of China: Final Results of Countervailing Duty Administrative Review, and Partial Rescission of Countervailing Duty Administrative Review; 2014-2015. In 2017-19292, edited by U.S. International Trade Administration. https://www.federalregister.gov/documents/2017/09/12/2017-19292/certain-crystallinesilicon-photovoltaic-products-from-the-peoples-republic-of-china-final-results: The Office of the U.S. Federal Register.

U.S. International Trade Administration. 2017d. Certain Crystalline Silicon Photovoltaic Products From the People's Republic of China: Notice of Court Decision Not in Harmony With Amended Final Affirmative Countervailing Duty Determination. In 2017-24516, edited by U.S. International Trade Administration. https://www.federalregister.gov/documents/2017/11/13/2017-24516/certain-crystallinesilicon-photovoltaic-products-from-the-peoples-republic-of-china-notice-of-court: The Office of the U.S. Federal Register.

U.S. International Trade Administration. 2017e. Certain Crystalline Silicon Photovoltaic Products From the People's Republic of China: Rescission of Antidumping Duty Administrative Review. In 2017-17361, edited by U.S. International Trade Administration. https://www.federalregister.gov/documents/2017/08/17/201717361/certain-crystalline-silicon-photovoltaic-products-from-the-peoples-republic-ofchina-rescission-of: The Office of the U.S. Federal Register.

U.S. International Trade Administration. 2017f. Crystalline Silicon Photovoltaic Cells, Whether or Not Assembled Into Modules, From the People's Republic of China: Amended Final Results of Countervailing Duty Administrative Review; 2014. In 2017-21589, edited by U.S. International Trade Administration. https://www.federalregister.gov/documents/2017/10/06/2017-21589/crystalline-siliconphotovoltaic-cells-whether-or-not-assembled-into-modules-from-the-peoples: The Office of the U.S. Federal Register.

U.S. International Trade Administration. 2017g. Crystalline Silicon Photovoltaic Cells, Whether or Not Assembled Into Modules, From the People's Republic of China: Final Results of Antidumping Duty Administrative Review and Final Determination of No Shipments; 2014-2015. In 2017-13462, edited by U.S. International Trade Administration. https://www.federalregister.gov/documents/2017/06/27/2017-13426/crystalline-siliconphotovoltaic-cells-whether-or-not-assembled-into-modules-from-the-peoples: The Office of the U.S. Federal Register.

U.S. International Trade Administration. 2018a. Certain Crystalline Silicon Photovoltaic Products From Taiwan: Final Results of Antidumping Duty Administrative Review; 2016-2017. In 2018-13858, edited by U.S. International Trade Administration. https://www.federalregister.gov/documents/2018/06/28/2018-13858/certain-crystallinesilicon-photovoltaic-products-from-taiwan-final-results-of-antidumping-duty: The Office of the U.S. Federal Register. 
U.S. International Trade Administration. 2018b. Commerce Finds Dumping and Countervailable Subsidization of Imports of Plastic Decorative Ribbon from China.

https://enforcement.trade.gov/download/factsheets/factsheet-prc-plastic-decorativeribbon-ad-cvd-final-122118.pdf.

U.S. International Trade Administration. 2018c. Crystalline Silicon Photovoltaic Cells, Whether or Not Assembled Into Modules, From the People's Republic of China: Amended Final Results of Countervailing Duty Administrative Review; 2015. In 2018-23667, edited by U.S. International Trade Administration.

https://www.federalregister.gov/documents/2018/10/30/2018-23667/crystalline-siliconphotovoltaic-cells-whether-or-not-assembled-into-modules-from-the-peoples: The Office of the U.S. Federal Register.

U.S. International Trade Administration. 2018d. Crystalline Silicon Photovoltaic Cells, Whether or Not Assembled Into Modules, From the People's Republic of China: Final Results of Antidumping Duty Administrative Review and Final Determination of No Shipments; 2015-2016. In 2018-16072, edited by U.S. International Trade Administration. https://www.federalregister.gov/documents/2018/07/27/2018-16072/crystalline-siliconphotovoltaic-cells-whether-or-not-assembled-into-modules-from-the-peoples: The Office of the U.S. Federal Register.

U.S. International Trade Administration. 2018e. Crystalline Silicon Photovoltaic Cells, Whether or Not Assembled Into Modules, From the People's Republic of China: Final Results of Countervailing Duty Administrative Review; 2015. In 2018-15692, edited by U.S. International Trade Administration. https://www.federalregister.gov/documents/2018/07/23/2018-15692/crystalline-siliconphotovoltaic-cells-whether-or-not-assembled-into-modules-from-the-peoples: The Office of the U.S. Federal Register.

U.S. International Trade Administration. 2019a. Aluminum Extrusions From the People's Republic of China: Initiation of Anti-Circumvention and Scope Inquiries on the Antidumping Duty and Countervailing Duty Orders. https://www.federalregister.gov/documents/2019/05/06/2019-09214/aluminumextrusions-from-the-peoples-republic-of-china-initiation-of-anti-circumvention-andscope.

U.S. International Trade Administration. 2019b. Certain Crystalline Silicon Photovoltaic Products From Taiwan: Notice of Court Decision Not in Harmony With the Final Results of the Antidumping Duty Administrative Review, 2014-2016; and Notice of Amended Final Results of the Antidumping Duty Administrative Review, 2014-2016. In 201912025, edited by U.S. International Trade Administration. https://www.federalregister.gov/documents/2019/06/07/2019-12025/certain-crystallinesilicon-photovoltaic-products-from-taiwan-notice-of-court-decision-not-in: The Office of the U.S. Federal Register.

U.S. International Trade Administration. 2019c. Certain Crystalline Silicon Photovoltaic Products From Taiwan: Preliminary Results of Antidumping Duty Administrative Review and Preliminary Determination of No Shipments; 2017-2018. In 2019-07428, edited by U.S. International Trade Administration. https://www.federalregister.gov/documents/2019/04/15/2019-07428/certain-crystallinesilicon-photovoltaic-products-from-taiwan-preliminary-results-of-antidumping: The Office of the U.S. Federal Register. 
U.S. International Trade Administration. 2019d. Certain Crystalline Silicon Photovoltaic Products From the People's Republic of China: Final Results of Antidumping Duty Administrative Review; 2017-2018. In 2019-12608, edited by U.S. International Trade Administration. https://www.federalregister.gov/documents/2019/06/14/201912608/certain-crystalline-silicon-photovoltaic-products-from-the-peoples-republic-ofchina-final-results: The Office of the U.S. Federal Register.

U.S. International Trade Administration. 2019e. Certain Crystalline Silicon Photovoltaic Products From the People's Republic of China: Notice of Court Decision Not in Harmony With Final Results of Antidumping Duty Administrative Review and Notice of Amended Final Results of Antidumping Duty Administrative Review. In 2019-20618, edited by U.S. International Trade Administration.

https://www.federalregister.gov/documents/2019/09/25/2019-20816/certain-crystallinesilicon-photovoltaic-products-from-the-peoples-republic-of-china-notice-of-court: The Office of the U.S. Federal Register.

U.S. International Trade Administration. 2019f. Certain Crystalline Silicon Photovoltaic Products From the People's Republic of China: Preliminary Results of Countervailing Duty Administrative Review, and Rescission of Review in Part; 2017. In 2019-07540, edited by U.S. International Trade Administration. https://www.federalregister.gov/documents/2019/04/16/2019-07540/certain-crystallinesilicon-photovoltaic-products-from-the-peoples-republic-of-china-preliminary: The Office of the U.S. Federal Register.

U.S. International Trade Administration. 2019g. Certain Crystalline Silicon Photovoltaic Products From the People's Republic of China: Rescission of Antidumping Duty Administrative Review; 2018-2019. In 2019-19867, edited by U.S. International Trade Administration. https://www.federalregister.gov/documents/2019/09/13/201919867/certain-crystalline-silicon-photovoltaic-products-from-the-peoples-republic-ofchina-rescission-of: The Office of the U.S. Federal Register.

U.S. International Trade Administration. 2019h. Crystalline Silicon Photovoltaic Cells, Whether or Not Assembled Into Modules, From the People's Republic of China: Final Results of Antidumping Duty Administrative Review and Final Determination of No Shipments; 2016-2017. In 2019-16159, edited by U.S. International Trade Administration. https://www.federalregister.gov/documents/2019/07/30/2019-16159/crystalline-siliconphotovoltaic-cells-whether-or-not-assembled-into-modules-from-the-peoples: The Office of the U.S. Federal Register.

U.S. International Trade Administration. 2019i. Crystalline Silicon Photovoltaic Cells, Whether or Not Assembled Into Modules, From the People's Republic of China: Final Results of Countervailing Duty Administrative Review and Rescission of Review, in Part; 2016. In 2019-18557, edited by U.S. International Trade Administration. https://www.federalregister.gov/documents/2019/08/28/2019-18557/crystalline-siliconphotovoltaic-cells-whether-or-not-assembled-into-modules-from-the-peoples: The Office of the U.S. Federal Register.

U.S. International Trade Commission. 2017. "Crystalline Silicon Photovoltaic Cells (Whether or Not Partially or Fully Assembled into Other Products)." Last Modified September 22, 2017, accessed May 24, 2019.

https://www.usitc.gov/press_room/news_release/2017/er092211832.htm. 
U.S. Office of the Federal Register. 2018a. "Exclusion of Particular Products From the Solar Products Safeguard Measure." accessed April 24, 2019.

https://www.federalregister.gov/documents/2018/09/19/2018-20342/exclusion-ofparticular-products-from-the-solar-products-safeguard-measure.

U.S. Office of the Federal Register. 2018b. "To Facilitate Positive Adjustment to Competition From Imports of Certain Crystalline Silicon Photovoltaic Cells (Whether or Not Partially or Fully Assembled Into Other Products) and for Other Purposes." accessed April 24, 2019. https://www.federalregister.gov/documents/2018/01/25/2018-01592/to-facilitatepositive-adjustment-to-competition-from-imports-of-certain-crystalline-silicon.

U.S. Office of the Federal Register. 2019. Exclusion of Particular Products From the Solar Products Safeguard Measure.

https://www.federalregister.gov/documents/2019/06/13/2019-12476/exclusion-ofparticular-products-from-the-solar-products-safeguard-measure.

U.S. Trade Representative. 2018. China Section 301-Tariff Actions and Exclusion Process. https://ustr.gov/issue-areas/enforcement/section-301-investigations/tariff-actions.

U.S. Trade Representative. 2019. Notice of Modification of Section 301 Action: China's Acts, Policies, and Practices Related to Technology Transfer, Intellectual Property, and Innovation. https://www.federalregister.gov/documents/2019/05/09/2019-09681/noticeof-modification-of-section-301-action-chinas-acts-policies-and-practices-related-to.

United States Congress. 2017. H.R.1 - 115th Congress (2017 - 2019). https://www.congress.gov/bill/115th-congress/house-bill/1.

Virginia Economic Development Partnership. 2019. Interim Status Report on Virginia Jobs Investment Program (VJIP). https://www.vedp.org/sites/default/files/201902/Interim $\% 20$ report $\% 20$ on $\% 20$ VJIP $\% 20$ projects $\% 20$ that $\% 20$ have $\% 20$ not $\% 20$ yet $\% 20$ re ached $\% 20$ their $\% 20$ Perf $\% 20$ Date $\% 20$ as $\% 20$ of $\% 2012-31-18$.pdf.

Weatherly, Jack. 2018. Magazine reports Seraphim shutdown; bigger things in works, solar panel maker says. Mississippi Business Journal. Accessed May 24, 2019.

Weaver, John. 2018a. Hanwha Q Cells to build America's largest solar module factory in Georgia. PV Magazine. Accessed April 18, 2019.

Weaver, John. 2018b. Hurricane Maria moves Solartech Universal's expansion to South Florida. https://pv-magazine-usa.com/2018/05/21/hurricane-maria-moves-solartech-universalexpansion-to-continental-us/.

Whalen, Ryan. 2019. Lt. Gov: Up to 50 Buffalo Employees May Be Affected By Tesla Layoffs. Spectrum News.

Wood Mackenzie. 2019. U.S. PV Leaderboard 2019. https://www.woodmac.com/ourexpertise/focus/Power--Renewables/U.S.-PV-Leaderboard/.

Wood Mackenzie Power \& Renewables, and SEIA. 2019a. U.S. Solar Market Insight Report 2018 Year In Review. https://www.seia.org/research-resources/solar-market-insightreport-2018-year-review.

Wood Mackenzie Power \& Renewables, and SEIA. 2019b. U.S. Solar Market Insight Report 2018 Year In Review. https://www.seia.org/research-resources/solar-market-insightreport-2018-year-review.

Wood Mackenzie Power \& Renewables, and SEIA. 2019. U.S. Solar Market Insight Report 2018 Year In Review. https://www.seia.org/research-resources/solar-market-insightreport-2018-year-review. 
Woodhouse, Michael, Brittany Smith, Ashwin Ramdas, and Robert Margolis. 2019. Crystalline Silicon Photovoltaic Module Manufacturing Costs and Sustainable Pricing: 1H 2018 Benchmark and Cost Reduction Roadmap. National Renewable Energy Laboratory: https://www.nrel.gov/docs/fy19osti/72134.pdf.

World Trade Organization. 2019. "Dispute Settlement DS437: United States - Countervailing Duty Measures on Certain Products from China." Last Modified August 20, 2019, accessed October 15, 2019.

https://www.wto.org/english/tratop_e/dispu_e/cases_e/ds437 e.htm\#bkmk437abrw.

Zhao, Zhen-yu, Shuang-Ying Zhang, Bryan Hubbard, and Xue Yao. 2013. "The emergence of the solar photovoltaic power industry in China." Renewable and Sustainable Energy Reviews 21:229-236. 


\section{Appendix}

Table 12. 2017-2019 Announcements of Plans to Add U.S. PV Manufacturing Capacity: by Size, Type, and Status as of July 2019

\begin{tabular}{|c|c|c|c|}
\hline Company & $\begin{array}{c}\text { 2017-2019 } \\
\text { Announcements } \\
\text { (GW/year) }\end{array}$ & Type & Status as of July 2019 \\
\hline Auxin Solar & 0.05 & c-Si modules & Full capacity \\
\hline CSUN & 0.6 & c-Si modules & No capacity confirmed yet \\
\hline First Solar & 1.2 & $\begin{array}{l}\text { Thin film } \\
\text { (CdTe) }\end{array}$ & Production started, full capacity expected soon \\
\hline GreenBrilliance & 0.125 & c-Si modules & Target date is late 2019 \\
\hline Hanwha Q Cells & 1.7 & c-Si modules & Production started, full capacity expected soon \\
\hline Heliene & 0.14 & c-Si modules & Full capacity \\
\hline JinkoSolar & 0.4 & c-Si modules & Full capacity \\
\hline LG Electronics & 0.5 & c-Si modules & Production started, full capacity expected soon \\
\hline Mission Solar & 0.2 & c-Si modules & No capacity confirmed yet \\
\hline $\begin{array}{r}\text { Seraphim } \\
\text { Manufacturing } \\
\text { USA }\end{array}$ & 0.36 & c-Si modules & No capacity confirmed yet \\
\hline Silfab & 0.25 & c-Si modules & Production started, full capacity expected soon \\
\hline $\begin{array}{r}\text { Solar Electric } \\
\text { America }\end{array}$ & 0.06 & c-Si modules & Full capacity \\
\hline $\begin{array}{l}\text { SolarCity/ } \\
\text { Panasonic }\end{array}$ & 0.9 & c-Si modules & Production started, full capacity expected soon \\
\hline $\begin{array}{l}\text { SolarCity/ } \\
\text { Panasonic }\end{array}$ & 0.9 & c-Si cells & Production started, full capacity expected soon \\
\hline $\begin{array}{l}\text { SolarTech } \\
\text { Universal }\end{array}$ & 0.18 & c-Si modules & No capacity confirmed yet \\
\hline SolSuntech & 0.1 & c-Si cells & Target date is late 2019 \\
\hline SolSuntech & 0.1 & c-Si modules & Target date is late 2019 \\
\hline SunPower & 0.22 & c-Si cells & No capacity confirmed yet \\
\hline SunPower & 0.22 & c-Si modules & Full capacity \\
\hline Sunpreme & 0.4 & c-Si cells & No capacity confirmed yet \\
\hline Sunpreme & 0.4 & c-Si modules & No capacity confirmed yet \\
\hline $\begin{array}{l}\text { Announced } \\
\text { Module Total }\end{array}$ & 7.5 & & \\
\hline $\begin{array}{l}\text { Announced Cell } \\
\text { Total }\end{array}$ & 1.6 & & \\
\hline $\begin{array}{l}\text { Initiated } \\
\text { Module Total }\end{array}$ & 5.6 & & \\
\hline $\begin{array}{l}\text { Initiated Cell } \\
\text { Total }\end{array}$ & 0.9 & & \\
\hline
\end{tabular}


Table 13. 2017-2019 Announcements of Plans to Add U.S. PV Manufacturing Capacity by U.S. Presence, Country of Origin, Cell Sourcing, Cell Architecture, Facility Type, and Target Markets

\begin{tabular}{|c|c|c|c|c|c|c|}
\hline Name & U.S. Presence & Country HQ & $\begin{array}{c}\text { Cell } \\
\text { Sourcing }\end{array}$ & $\begin{array}{c}\text { Cell } \\
\text { Architecture }\end{array}$ & Facility Type & Target Market \\
\hline Auxin Solar & $\begin{array}{l}\text { Existing U.S. PV } \\
\text { manufacturing } \\
\text { capacity }\end{array}$ & U.S. & $\begin{array}{l}\text { Taiwan/ } \\
\text { Germany }\end{array}$ & Unknown & $\begin{array}{l}\text { Expansion of existing } \\
\text { facility }\end{array}$ & Unknown \\
\hline CSUN & $\begin{array}{l}\text { No previous U.S. } \\
\text { presence }\end{array}$ & China & Unknown & Unknown & Repurposed facility & Unknown \\
\hline First Solar & $\begin{array}{l}\text { Existing U.S. PV } \\
\text { manufacturing } \\
\text { capacity }\end{array}$ & U.S. & U.S. (CdTe) & CdTe & Greenfield & $\begin{array}{c}\text { Utility/ } \\
\text { commercial }\end{array}$ \\
\hline GreenBrilliance & $\begin{array}{l}\text { U.S. installer with } \\
\text { India module } \\
\text { production }\end{array}$ & U.S. & $\begin{array}{l}\text { India } \\
\text { assumed }\end{array}$ & Unknown & Unknown & $\begin{array}{l}\text { Residential/ } \\
\text { commercial }\end{array}$ \\
\hline Hanwha Q Cells & $\begin{array}{l}\text { No previous U.S. } \\
\text { presence }\end{array}$ & Korea & Korea & Mono-PERC & Greenfield & Utility \\
\hline Heliene & $\begin{array}{c}\text { No previous U.S. } \\
\text { presence }\end{array}$ & Canada & Unknown & Mono-PERC & $\begin{array}{l}\text { Retooled old PV } \\
\text { facility }\end{array}$ & $\begin{array}{c}\text { Utility/ } \\
\text { commercial }\end{array}$ \\
\hline JinkoSolar & $\begin{array}{c}\text { No previous U.S. } \\
\text { presence }\end{array}$ & China & Malaysia & Mono-PERC & Repurposed facility & Utility \\
\hline LG Electronics & $\begin{array}{l}\text { Non-PV U.S. } \\
\text { manufacturing }\end{array}$ & Korea & Korea & Mono & Repurposed facility & $\begin{array}{l}\text { Residential/ } \\
\text { commercial }\end{array}$ \\
\hline Mission Solar & $\begin{array}{l}\text { Existing U.S. PV } \\
\text { manufacturing } \\
\text { capacity }\end{array}$ & U.S. & Korea & Unknown & $\begin{array}{l}\text { Expansion of existing } \\
\text { facility }\end{array}$ & Unknown \\
\hline $\begin{array}{l}\text { Seraphim Solar } \\
\text { USA }\end{array}$ & $\begin{array}{c}\text { Existing U.S. PV } \\
\text { manufacturing } \\
\text { capacity }\end{array}$ & $\begin{array}{l}\text { U.S. subsidiary of } \\
\text { Chinese parent } \\
\text { company }\end{array}$ & Unknown & Mono-PERC & $\begin{array}{l}\text { Expansion of existing } \\
\text { facility }\end{array}$ & $\begin{array}{l}\text { Residential/ } \\
\text { commercial }\end{array}$ \\
\hline Silfab & $\begin{array}{l}\text { No previous U.S. } \\
\text { presence }\end{array}$ & $\begin{array}{c}\text { Canadian } \\
\text { subsidiary of } \\
\text { Italian company }\end{array}$ & $\begin{array}{l}\text { MWT cells } \\
\text { from } \\
\text { Taiwan }\end{array}$ & Mono-PERC & $\begin{array}{l}\text { Expansion of existing } \\
\text { facility }\end{array}$ & $\begin{array}{l}\text { Residential/ } \\
\text { commercial }\end{array}$ \\
\hline $\begin{array}{l}\text { Solar Electric } \\
\text { America }\end{array}$ & Installer & U.S. & Unknown & Unknown & Repurposed facility & Unknown \\
\hline $\begin{array}{l}\text { SolarCity \& } \\
\text { Panasonic }\end{array}$ & $\begin{array}{l}\text { Existing U.S. PV } \\
\text { manufacturing } \\
\text { capacity }\end{array}$ & $\begin{array}{l}\text { U.S. \& Japan } \\
\text { partnership }\end{array}$ & U.S. & Unknown & Repurposed facility & Unknown \\
\hline $\begin{array}{l}\text { SolarTech } \\
\text { Universal }\end{array}$ & $\begin{array}{l}\text { Existing U.S. PV } \\
\text { manufacturing } \\
\text { capacity }\end{array}$ & U.S. & Unknown & Unknown & Unknown & $\begin{array}{l}\text { Residential/ } \\
\text { commercial }\end{array}$ \\
\hline SolSuntech & $\begin{array}{l}\text { No previous U.S. } \\
\text { presence }\end{array}$ & U.S. & $\begin{array}{l}\text { U.S. } \\
\text { planned }\end{array}$ & Unknown & Repurposed facility & $\begin{array}{l}\text { Residential/ } \\
\text { commercial }\end{array}$ \\
\hline SunPower & $\begin{array}{l}\text { Existing U.S. PV } \\
\text { manufacturing } \\
\text { capacity }\end{array}$ & U.S. & $\begin{array}{l}\text { U.S. } \\
\text { planned }\end{array}$ & PERC & $\begin{array}{l}\text { Retooled old PV } \\
\text { facility }\end{array}$ & Residential \\
\hline Sunpreme & $\begin{array}{c}\text { R\&D facility, } 60 \% \\
\text { use of U.S. module } \\
\text { OEM }\end{array}$ & U.S. & $\begin{array}{l}\text { U.S. } \\
\text { planned }\end{array}$ & SHJ-like & Unknown & $\begin{array}{l}\text { Residential/ } \\
\text { commercial }\end{array}$ \\
\hline
\end{tabular}


Table 14. 2017-2019 Announcements of Plans to Add U.S. PV Manufacturing Capacity: Jobs Data and References

\begin{tabular}{|c|c|c|c|}
\hline Name & Jobs & $\begin{array}{c}\text { Per Capacity } \\
\text { Reported Below } \\
\text { (GW/year) }\end{array}$ & Reference \\
\hline Auxin Solar & 60 & 0.15 & (Pickerel 2018b) \\
\hline CSUN & 200 & 0.4 & (McClellan Park 2017) \\
\hline First Solar & 500 & 1.2 & (Rogers 2018) \\
\hline GreenBrilliance & -- & -- & -- \\
\hline Hanwha Q Cells & 750 & 1.7 & (Oliver 2019) \\
\hline Heliene & 120 & 0.14 & (Hughlett 2019) \\
\hline JinkoSolar & 200 & 0.4 & (Pickerel 2019b) \\
\hline LG Electronics & 160 & 0.5 & (Pyper 2018) \\
\hline Mission Solar & -- & -- & -- \\
\hline Seraphim Solar USA & -- & -- & -- \\
\hline Silfab & 200 & 0.4 & (Foehringer Merchant 2019) \\
\hline Solar Electric America & -- & -- & -- \\
\hline SolarCity \& Panasonic & 1,500 & 1 & (Whalen 2019) \\
\hline Solaria & 20 & $<0.04$ & (Groom 2018) \\
\hline SolarTech Universal & -- & -- & -- \\
\hline SolSuntech & 132 & 0.1 & (SolSuntech 2018) \\
\hline SunPower & 200 & 0.22 & (Sylvia 2019) \\
\hline Sunpreme (Nevada) & 200 & 0.3 & $\begin{array}{c}\text { (Nevada Governor's Office of Economic } \\
\text { Development 2017) }\end{array}$ \\
\hline TOTAL & 4,240 & & \\
\hline
\end{tabular}


Table 15. 2017-2019 Announcements of Plans to Add U.S. PV Manufacturing Capacity: CapEx Data and References

\begin{tabular}{|c|c|c|c|}
\hline Name & CapEx & $\begin{array}{l}\text { Per Capacity } \\
\text { Reported Below } \\
\text { (GW/year) }\end{array}$ & Reference \\
\hline Auxin Solar & $\$ 3.5$ million & 0.125 & Verbal discussion \\
\hline CSUN & -- & -- & -- \\
\hline First Solar & $\$ 400$ million & 1.2 & (Pickerel 2018a) \\
\hline GreenBrilliance & -- & -- & -- \\
\hline Hanwha Q Cells & $\$ 150$ million & 1.7 & (Flessner 2018) \\
\hline Heliene & \$18 million & 0.14 & (Hughlett 2019) \\
\hline JinkoSolar & $\$ 50$ million & 0.4 & (Basch 2018) \\
\hline LG Electronics & $\$ 28$ million & 0.5 & $\begin{array}{l}\text { (Alabama Office of the Governor } \\
\text { 2018) }\end{array}$ \\
\hline Mission Solar & -- & -- & -- \\
\hline Seraphim Solar USA & -- & -- & -- \\
\hline Silfab & $\$ 40$ million & 0.4 & (Hamann 2018) \\
\hline Solar Electric America & $\$ 1.2$ million & 0.06 & (Pickerel 2018b) \\
\hline SolarCity \& Panasonic & $\$ 950$ million & 1 & (Robinson and Precious 2017) \\
\hline Solaria & \$23 million & 0.2 & (Roselund 2018c) \\
\hline SolarTech Universal & -- & -- & -- \\
\hline SolSuntech & $\$ 33$ million & 0.1 & $\begin{array}{c}\text { (Virginia Economic Development } \\
\text { Partnership 2019) }\end{array}$ \\
\hline SunPower & $\$ 45$ million & 0.22 & $\begin{array}{c}\text { (Foehringer Merchant 2019; } \\
\text { Rogoway 2018) }\end{array}$ \\
\hline Sunpreme (Nevada) & $\$ 30$ million & 0.3 & $\begin{array}{l}\text { (Nevada Governor's Office of } \\
\text { Economic Development 2017) }\end{array}$ \\
\hline
\end{tabular}


Table 16. 2017-2019 Announcements of Plans to Add U.S. PV Manufacturing Capacity: Incentive Data and References

\begin{tabular}{|c|c|c|c|}
\hline Name & Incentives & $\begin{array}{c}\text { Per Capacity } \\
\text { Reported Below } \\
\text { (GW/year) }\end{array}$ & Reference \\
\hline Auxin Solar & -- & -- & -- \\
\hline CSUN & $\$ 0.7$ million & 0.4 & (McClellan Park 2017) \\
\hline First Solar & -- & -- & -- \\
\hline GreenBrilliance & -- & -- & -- \\
\hline Hanwha Q Cells & $\$ 30$ million & 1.7 & (Weaver 2018a) \\
\hline Heliene & $\$ 1$ million & 0.14 & (Hughlett 2019) \\
\hline JinkoSolar & \$3.4 million & 0.4 & (Basch 2018) \\
\hline LG Electronics & -- & -- & -- \\
\hline Mission Solar & -- & -- & -- \\
\hline Seraphim Solar USA & -- & -- & -- \\
\hline Silfab & -- & -- & -- \\
\hline Solar Electric America & -- & -- & -- \\
\hline SolarCity \& Panasonic & $\$ 750$ million & 1 & (Robinson and Precious 2017) \\
\hline Solaria & -- & -- & -- \\
\hline SolarTech Universal & -- & -- & -- \\
\hline SolSuntech & $\$ 5.5$ million & 0.1 & (Nsehe 2019) \\
\hline SunPower & -- & -- & -- \\
\hline Sunpreme (Nevada) & $\$ 3.2$ million & 0.3 & $\begin{array}{l}\text { (Nevada Governor's Office of } \\
\text { Economic Development 2017) }\end{array}$ \\
\hline
\end{tabular}

